\title{
Biotic complexes of the Arctic Ocean
}

\begin{abstract}
A.N. Mironov
P.P. Shirshov Institute of Oceanology, Russian Academy of Sciences, Nakhimovsky Prospekt, 36, 117997, Moscow, Russia; e-mail: miron@ocean.ru
\end{abstract}

ABSTRACT: There are three main approaches to biogeographical regionalization: the species (or faunistic, floristic, biotic), community (biocenotic) and landscape (bionomic) approaches. They differ over seven criteria. Areographic analysis is used in the biotic approach. The biocenotic approach is often based on the cluster analysis. The biotic approach adopts the assumption of continuity in a species range, whereas in the biocenotic approach a species range is considered as interrupted. Environmental data are not used in these two approaches. The use of environmental data at the initial stage of regionalization is the main distinguishing character of landscape biogeography. More than 70 schemes of biogeographical regionalization of the Arctic seas or the whole Arctic Ocean have been compared. Most biogeographic schemes were constructed based on methods using elements of biotic, biocenotic and landscape approaches. The number of biogeographic regions recognized on the Arctic shelf increases from schemes based purely on the biotic approach to those based on mixed elements of the biotic and biocenotic approaches, and increases further in schemes based on the biocenotic, landscape and mixed biocenoticlandscape approaches. The pure biotic approach revealed only three biogeographic regions on the Arctic shelf plus one region in the deep-sea. The biocenotic-landscape approach gave more than 50 biogeographic regions (the sum of suggested subdivisions) in the Arctic Ocean. A group of small biocenotic-landscape regions falls into one large biotic province. The biotic boundaries (zones of crowding of species ranges) in the Arctic Ocean overlap by up to several hundred $\mathrm{km}$, whereas the biocenotic and landscape boundaries are linear. Some biocenotic-landscape provinces completely fall into zones of crowding of species ranges. A biotic complex is defined as a totality of living organisms or a totality of communities occurring in a region outlined by a crowding zone. A biotic complex together with a biogeographic (biotic) region is considered as a large ecosystem or biogeocomplex. The results of the biogeographic regionalization of the Arctic Ocean support the hypothesis that a biotic complex is a large universal structural-functional unit of the living realm. In theory any biotic boundary can be revealed by different approaches to biogeographical regionalization at the large scale - biotic, biocenotic or landscape. On the other hand most biogeographic boundaries, revealed by biocenotic and landscape approaches, are not biotic boundaries. It is suggested that initially broad biotic boundaries evolved into narrow ones. The gradual convergence of species range limits as a result of common species adaptations was termed "the crowding effect of adaptations". Based on this approach, the great width of crowding zones in the Arctic Ocean reflects a young age of the Arctic biotic complexes. The latter in turn is explained by young geological age of the present-day Arctic environments.

KEY WORDS: Arctic, fauna, flora, biotic complex, biogeographic regionalization, crowding zone, ecosystem. 


\title{
Биотические комплексы Северного Ледовитого океана
}

\section{А.Н. Миронов}

\author{
Институт океанологии им. П.П. Ширшова РАН, Нахимовский пр., 36, Москва 117997; е- \\ mail:miron@ocean.ru
}

РЕЗЮМЕ: Разнообразие подходов к биогеорафическому районированию сведено к трем основным типам: видовой (или фаунистический, флористический, биотический), биоценотический (распределение сообществ) и ландшафтный (биономический). Они различаются с помощью семи критериев. Биотический подход использует ареографический анализ; биоценотический подход часто основан на кластерном анализе. При биотическом подходе принимается допущение о непрерывности видового ареала, в то время как при биоценотическом подходе видовой ареал считается прерывистым. Данные об окружающей среде исключаются из рассмотрения при последних двух подходах. Использование данных о неживом окружении на начальных стадиях районирования рассматривается как главный диагностический признак ландшафтной биогеографии. Проведено сравнение более чем 70 схем биогеографического районирования арктических морей или Северного Ледовитого океана в целом. Большинство биогеографических схем построено с помощью методов, использующих элементы биотического, биоценотического и ландшафтного подходов. Число биогеографических регионов, выделенных на арктическом шельфе, возрастает от схем, основанных на чисто биотическом подходе, к схемам, основанным на смешении элементов биотического и биоценотического подходов, и возрастает далее в схемах, основанных на биоценотическом, ландшафтном и смешанном ландшафтно-биоценотическом подходах. Чисто биотический подход позволяет выявлять только три биогеографических региона на арктическом шельфе плюс один регион в океанических глубинах. Ландшафтно-биоценотические подходы дают более 50 биогеографических регионов (если сложить максимальные числа регионов, предложенные для отдельных арктических морей). Группа ландшафтно-биоценотических регионов помещается в пределах одного биотического региона. Биотические границы (зоны сгущения границ видовых ареалов) имеют ширину до нескольких сотен километров, в то время как биоценотические и ландшафтные границы линейные. Некоторые ландшафтно-биоценотические провинции полностью помещаются в зоны сгущения границ видовых ареалов. Биотический комплекс определяется как множество живых организмов или множество сообществ, обитающих в регионе, очерченной зоной сгущения. Биотический комплекс совместно с биогеографическим (биотическим) регионом составляют крупную экосистему или биогеокомплекс. Результаты биогеографического районирования Северного Ледовитого океана поддерживают гипотезу о биотическом комплексе как о крупной универсальной структурно-функциональной единице живого покрова Земли. Теоретически любая биотическая граница может быть выявлена с помощью разных подходов к биогеографическому районированию: биотического, биоценотического и ландшафтного. С другой стороны, большинство биогеографических границ, выделяемых с помощью биоценотического и ландшафтного подходов, не являются биотическими границами. Предполагается, что изначально широкая биотическая граница эволюционирует в более узкую границу. Постепенное сближение границ видовых ареалов по причине развития у видов коадаптаций обозначается как группирующий эффект адаптаций. На основе этих представлений большая ширина зон сгущения рассматривается как свидетельство молодости арктических биотических комплексов. Эта молодость связана в свою очередь с молодым геологическим возрастом современных условий обитания в Северном Ледовитом океане. 
КЛЮЧЕВЫЕ СЛОВА: арктический, фауна, флора, биотический комплекс, биогеографическое районирование, зона сгущения, экосистема.

\section{Introduction}

Various aspects of biogeographic regionalization of the Arctic Ocean were considered in publications starting from the mid- $19^{\text {th }}$ century (Dana, 1853; Schmarda, 1853; Forbes, 1856; Lütken, 1857; Woodward, 1866). Since then, numerous biogeographical schemes related to the Arctic seas have been published. Several reviews of Arctic biogeography were made including Derjugin (1915), Briggs (1974), Semenov (1986), Krayushkina (2000) and Dinter (2001).

The suggested regionalization schemes differ from each other in the geographical position of borders and in the number and size of biogeographic subdivisions. Depending on the author's opinion, the number of biogeographic subdivisions changes from one region or subregion occupying nearly the entire Arctic shelf (usually excluding the shelf of the Norwegian Sea and the western Barents Sea) (Schmidt, 1904; Hedgpeth, 1957; Briggs, 1974, 1995; Vasilenko, 1974; Kussakin, 1979; Andriyashev, Shaposhnikov, 1985; Gontar, Denisenko, 1989) to several units within a single sea of the Arctic (Lubinsky, 1980; Naumov, Fedyakov, 1987; Gukov, 1999; Anisimova, 2000b; Krayushkina, 2000; Naumov, 2006; Zenzerov et al., 2006; Lyubina, Sayapin, 2008; Petrov, 2009).

Such a big difference in results can be explained primarily by the difference in methods and approaches applied to the biogeographic regionalization. There are three main approaches to biogeographical regionalization: the species (or faunistic, floristic, biotic), community (biocenotic) and landscape (bionomic) approaches. Most works on biogeographic regionalization of the Arctic Ocean contain mixed elements of these different approaches. Even when application of certain criteria is declared, they are often substituted by criteria of another nature.

In recent decades, the mixed approach to biogeographic regionalization has become more frequent. This tendency in part results from growing activities in ecosystem management and its application to large marine ecosystems and ecoregions from a scientific, legal, and political perspective. Also there is the assumption that a number of criteria used for regionalization positively correlates with the reliability of results.

Mironov (1999, 2004, 2012) suggested that a group of small biogeographical regions, revealed by biocenotic (=community) or/and landscape approaches could fall into one large biotic (=species) province. If this is true, then a universal structural-functional unit of a living realm should be independently revealed by different approaches. Such a universal unit has been called a biotic complex - the totality of organisms inhabiting an area outlined by zones of crowding of species range limits. To confirm the existence of such a unit, it is necessary to correctly differentiate the biotic, biocenotic and landscape approaches, and based on these approaches, to reveal biotic, biocenotic and landscape provinces, and to estimate the degree of their spatial coincidence.

In the present study we: (1) define the basic concepts of biotic biogeography and differentiate the biotic approach from the biocenotic and landscape approaches; (2) estimate the number of biogeographic provinces revealed by different approaches and the overlap of boundaries identified by the different schemes; (3) give the ecosystem interpretation of biotic complexes in the Arctic Ocean.

\section{Study area}

The International Hydrographic Organization defined the limits of the Arctic Ocean as the northern borders of the Arctic marginal seas (Limits of Oceans and Seas, 1953). However, the Arctic Ocean is often treated as having broader geographical boundaries. According to Jakobsson et al. (2008), it consists of the deepsea basins (excluding the Norwegian and Greenland basins), the Barents, White, Kara, Laptev, East Siberian, Chukchi, Beaufort and Lincoln Seas, and the narrow shelf off northern Greenland and the Canadian Arctic Archipelago (excluding the archipelago itself). Pidwirny (2006) additionally includes in the Arctic Ocean the 
Greenland Sea, Baffin and Hudson Bays, the Hudson Strait and the straits of the Canadian Arctic Archipelago. The Norwegian Sea was assigned to the Atlantic. One of the broadest concepts of the Arctic Ocean was given in the "Atlas of the Arctic" (Leontjev, 1985; Treshnikov, 1985), with the Arctic border going along the eastern entrance to the Hudson Bay, the northern boundary of the Davies Strait $\left(\right.$ at $\left.70^{\circ} \mathrm{N}\right)$ and along the southern boundaries of the Greenland and Norwegian seas. In the Pacific sector, the border goes along the latitude of the Cape Unikyn (Chukchi Peninsula) up to its intersection with the Seward Peninsula coast (Fig. 1). The Norwegian, Iceland and Chukchi Seas were included in the Arctic Ocean as the southernmost regions.

This broad concept of the Arctic Ocean is convenient for biogeographic issues since in the broad concept borders are drawn according to geomorphological features. Therefore I will use a definition of the Arctic Ocean based the "Atlas of the Arctic" (Leontjev, 1985; Treshnikov, 1985). The Greenland-Scotland Ridge separates the deep Arctic from the Atlantic. The ridge has a mean depth of 300-400 $\mathrm{m}$ with the deepest sills in the Faroe Bank Channel $(\sim 850$ $\mathrm{m})$ and in the Denmark Strait $(\sim 620 \mathrm{~m})$. The broad shelves of the Chukchi and Bering Seas separate the Arctic basin from the Pacific. These areas act as effective biogeographic barriers for benthic deep-sea fauna.

It is important to distinguish two meanings of the definition "arctic": (1) species found in the Arctic Ocean and (2) species found in the arctic latitudinal biotic (faunistic) zone. In the first case "Arctic" is written with a capital letter, in the second case - with a lower-case letter. The fauna of the Arctic Ocean consists of Arctic, Arctic-Atlantic, Arctic-Pacific and ArcticAtlantic-Pacific species. The fauna of the arctic latitudinal zone consists mainly of arctic, arcticboreal and arctic-boreal-subtropical species. On the European shelf, the boundary between the Arctic and Atlantic species goes along the Iceland-Faeroe Ridge, whereas the boundary between arctic and boreal species lies in the western Barents Sea (see section 9).

\section{Delimitation of the biotic, bio- cenotic and landscape approaches to biogeographic regionalization}

Following Starobogatov (1982), biogeography is defined here as a science on the distribution of any life manifestations. Biogeography is the study of the distribution of biological objects of any nature over the face of the earth. In accordance with approaches to regionalization, biogeography, in a wide sense, is subdivided into the biotic (species based approach), biocenotic (community approach) and landscape (landscape approach) biogeographies.

The biotic (species) approach to regionalization is based on the analysis of disposition of areas with respect to each other. Areographic analysis starts with a spatial representation of a species by an area (Fig. 2). When the borders of species ranges, and the lacunae within them, are plotted on a map, a complex pattern of closed lines, forming the lacework of a species range emerges (Beklemishev, 1969). Biotic biogeography adopts the assumption of the continuity of a species range (Mironov, 1990, 2004). This assumption is aimed at a large-scale chorological analysis at the level of the full ranges of species. It excludes from consideration boundaries of species populations and allows retaining the entity of species as the minimum biological objects of investigation. From the global chorological point of view, any species is represented by an uninterrupted area contoured by a single line connecting the outlying points of a species occurrence (Hesse, 1924; Beklemishev, 1969; Udvardy, 1969; Mironov, 1990, 2004). The actual mosaic pattern of a species distribution is disregarded in the biotic biogeography. However, when the disruption of a species range occurs over hundreds or thousands of kilometres, areographic analysis considers only the most significant part of a species range - a line connecting closely situated points of a species occurrence. The imitative part of a species range limit, i.e. a line connecting distant points of species records, is excluded (Fig. 2).

Analysis of numerous species ranges shows that their limits tend to cluster in certain areas (Drude, 1890; Kuznetsov, 1936; Walter, Alekhin, 1936; Szafer, 1952; Hagmeier, Stults, 1964; Valentine, 1966; Udvardy, 1969; Rapo- 


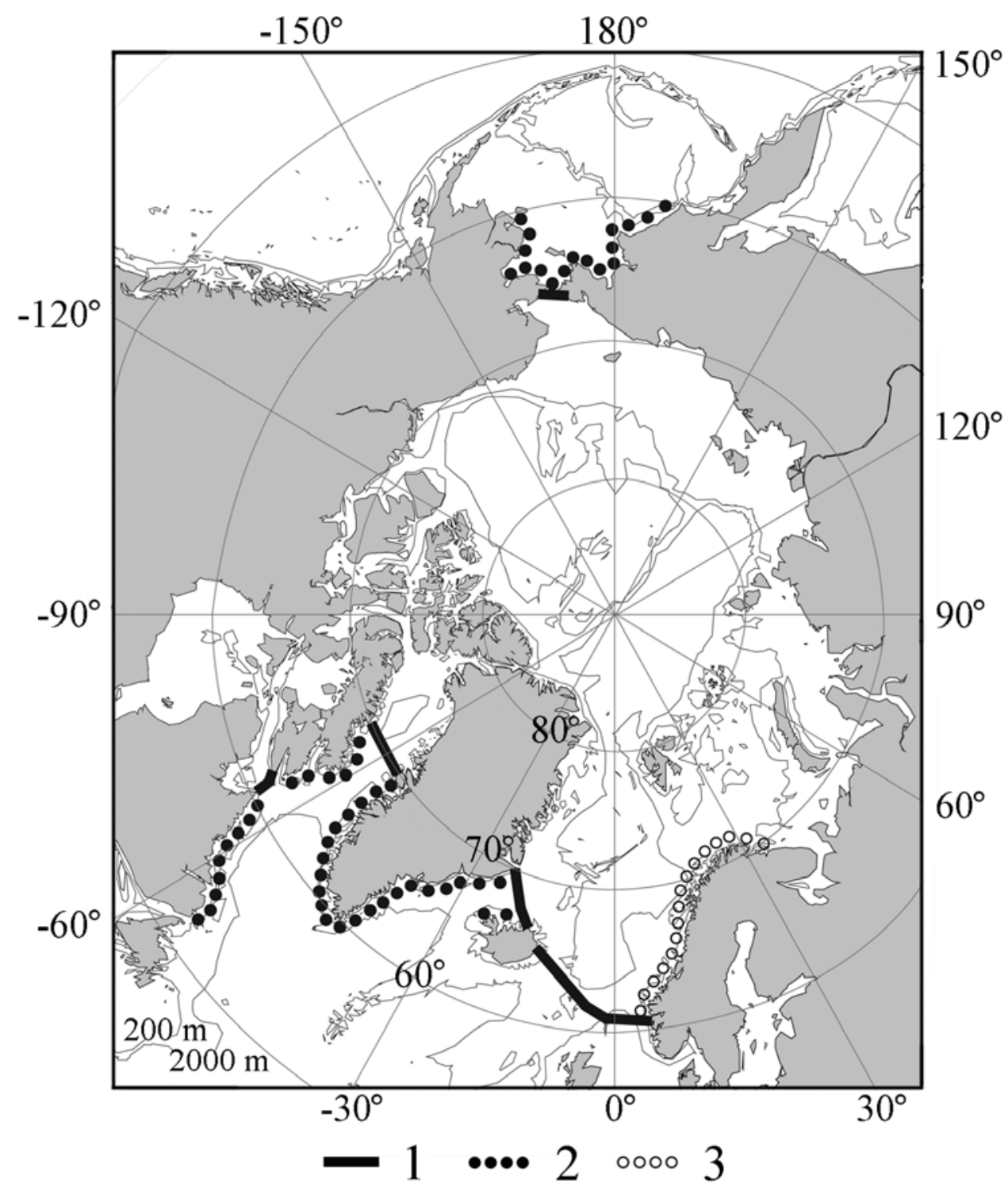

Fig. 1. Non-coincidence of biogeographic boundaries with boarders of the Arctic Ocean.

1 - borders of the Arctic Ocean, after Leontjev (1985) and Treshnikov (1985), 2 - areas of the Arctic (Shelf) Region outside the Arctic, 3 - areas of the Eastern Atlantic Boreal Region within the Arctic. Boundaries and names of biogeographic regions are given after Briggs $(1974,1995)$.

Рис. 1. Несовпадение биогеографических границ с границами Северного Ледовитого океана. 1 - границы Северного Ледовитого океана; по Леонтьеву (1985) и Трешникову (1985), 2 - районы Арктической (Шельфовой) Области, расположенные за пределами Северного Ледовитого океана, 3 - районы Восточной Атлантической Бореальной Области, расположенные в Северном Ледовитом океане. Границы и названия биогеографических областей по Briggs $(1974,1995)$.

port, 1982; Semenov, 1982; Mironov, 1990, 2004; Kafanov, 1991; Razumovsky, 1999; Spalding et al., 2007; Reaka et al., 2008; Roy et al., 2009; Jirkov, 2010). A zone where the borders of species ranges come close together is defined as a "biotic boundary". A "biotic region" is a territory outlined by zones of crowding of species range limits. On a map, a biotic boundary 


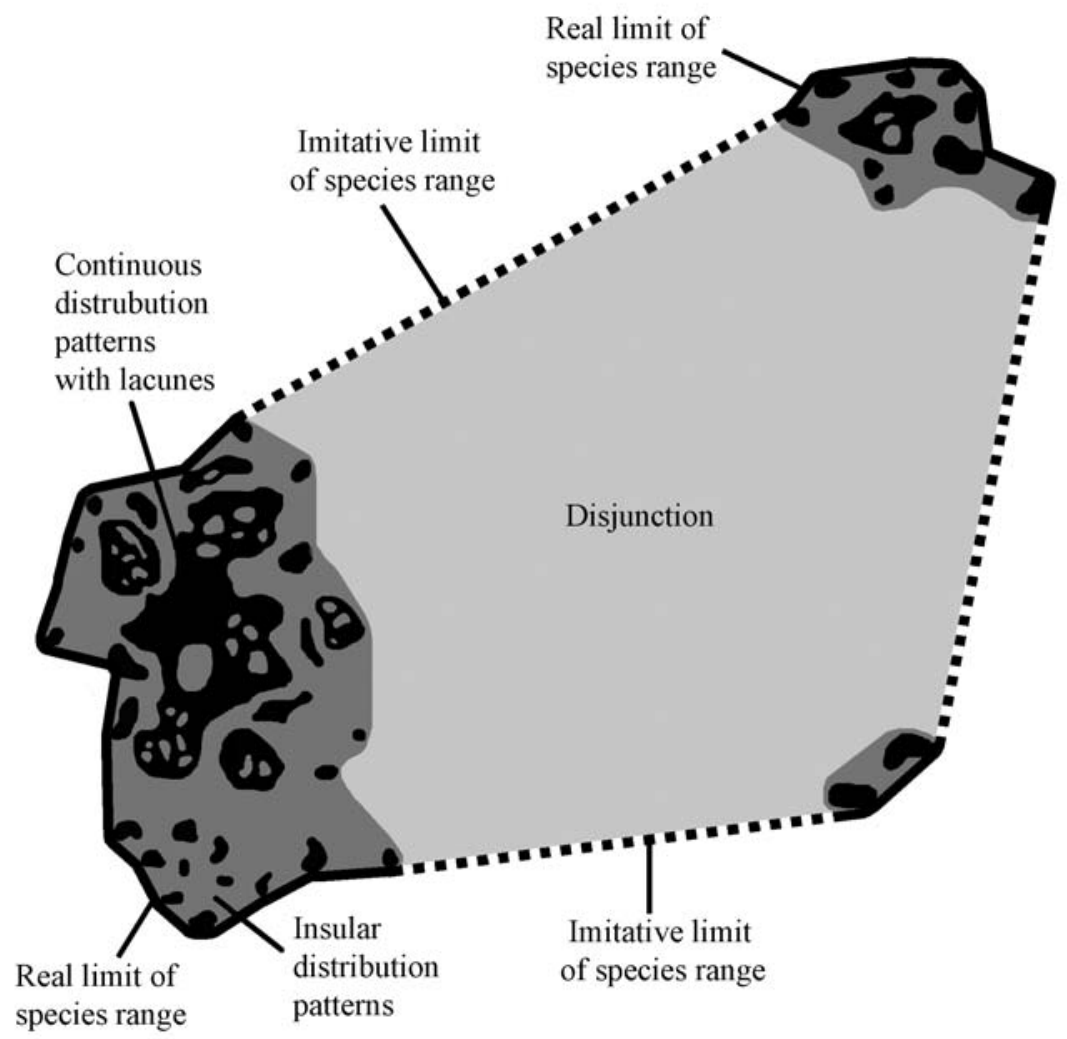

Fig. 2. Diagram illustrating disjunctive species range.

Рис. 2. Схема разорванного видового ареала.

appears as a crowding zone of lines of species range limits with a concentration of borders much higher that in neighbouring regions (Udvardy, 1969, fig. 5-1). These "crowding zones" are seen only when the line distribution is analysed in a wider space.

Two neighbouring areas are recognized as two biogeographic subdivisions if their faunas differ significantly from each other. However this criterion is insufficient to recognize the biotic subdivisions. Any crowding zone is a stepwise (not gradual or mosaic) change of species composition (Fig. 3). A crowding zone indicates a relatively high rate of species replacement (biota turnover). Kuznetsov (1936) introduced the term 'synperate' to indicate the zones of crowding of species range limits (see also Kafanov, Kudryashov, 2000). Razumovsky (1999) and Jirkov (2010) suggest that the limits of species ranges of species of the same type coincide completely. Jirkov (present issue) understands synperate as a line drawn along the outer edge of the crowding zone. However, full coincidence of numerous species range limits is unlikely. Zones of crowding, in most cases, are bands several tens of $\mathrm{km}$ wide.

Areographic analysis becomes much more complicated when species ranges and biotic regions are considered in three dimensions (3D). In the ocean vertical section, biotic regions are horizontal spaces, "biotic layers", replacing one another with increasing depth (Fig. 4). A boundary between shallow-water (upper) and deepwater (lower) biotic regions is revealed by the projection of upper and lower species range limits on a vertical plane. Fig. 4 shows a vertical section of adjacent shallow-water and deepwater biotic complexes. The shallow-water complex consists of three parts separated by deepwater areas (Fig. 4D). However, the assumption 

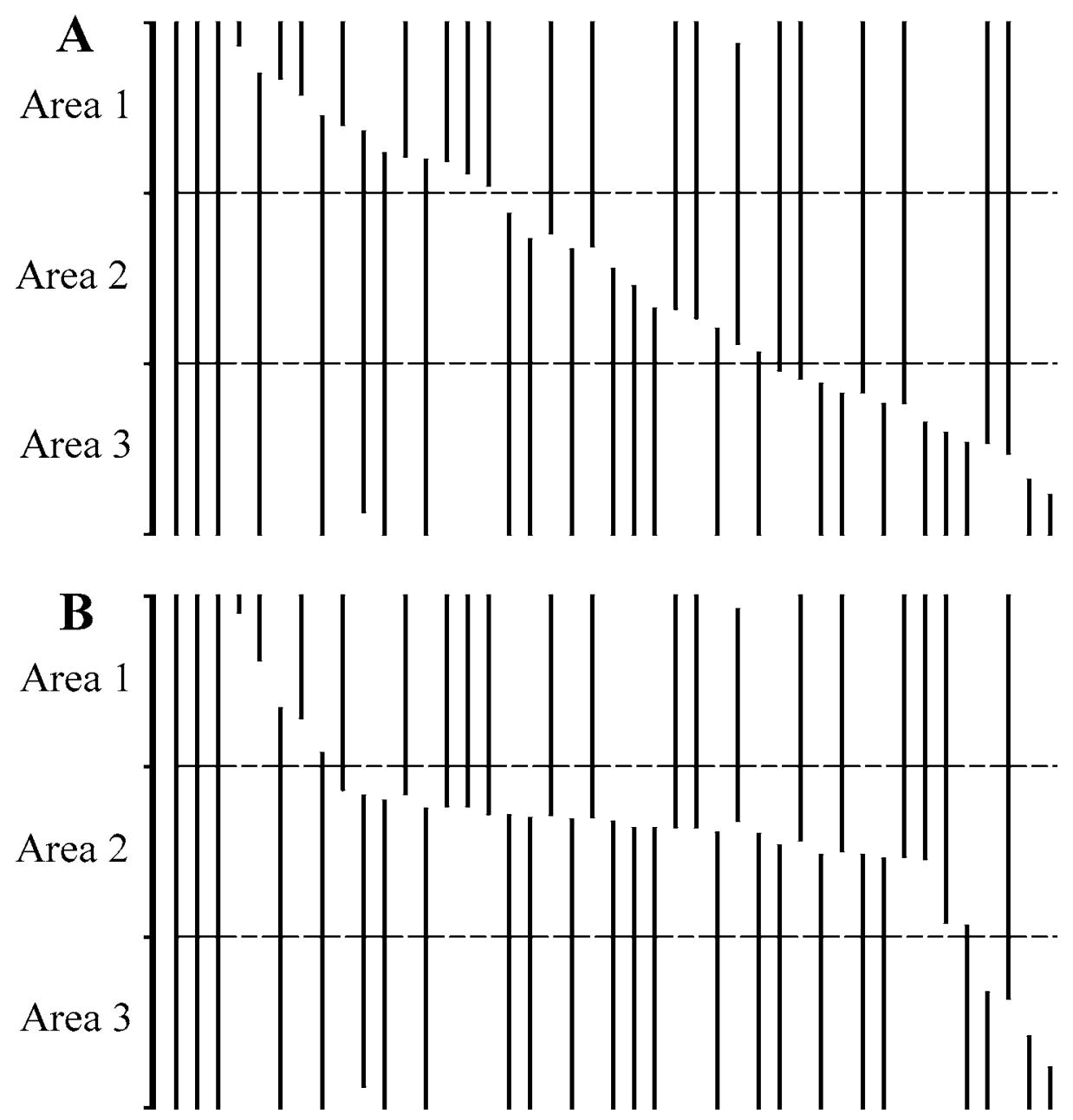

Fig. 3. Schemes of gradual (A) and stepwise (B) changes of species composition in three neighbouring areas. Vertical lines designate the species ranges. In the both cases (A and B), the biota of the area 1 differs significantly from the biota of the area 3. In the first case (A), the areas 1 and 3 don't have the status of biogeographic (biotic) subdivisions. In the second case (B), the areas 1 and 3 have the status of biogeographic subdivisions (units) separated from each other by a crowding zone (the area 2 ).

Рис. 3. Схема постепенного (А) и ступенчатого (В) изменений видового состава биоты в пределах трех соседних районов. Вертикальные линии обозначают видовые ареалы. В обоих случаях (А и В) биота района 1 существенно отличается от биоты района 3 . В первом случае (А) районы 1 и 3 не имеют статуса биогеографических (биотических) подразделений. Во втором случае (В) районы 1 и 3 имеют статус биогеографических подразделений (единиц), отделенных друг от друга зоной сгущения (район 2).

of continuity of a species range means the continuity of a biotic complex. Like a species range, each unit of biotic regionalization is an integral space (Fig. 4B, C). Thus, a boundary of a shallow-water biotic region is a continuous crowding zone, it outlines space including shallow-water areas (substantial parts of a crowding zone) and surface waters of deep-water areas (imitative parts of a crowding zone). The continuity of benthic biotic regions has a prognostic value: it assumes that any shallow-water area within boundaries of a continuous shallow-water biotic region will be inhabited by representatives of one biotic complex. 

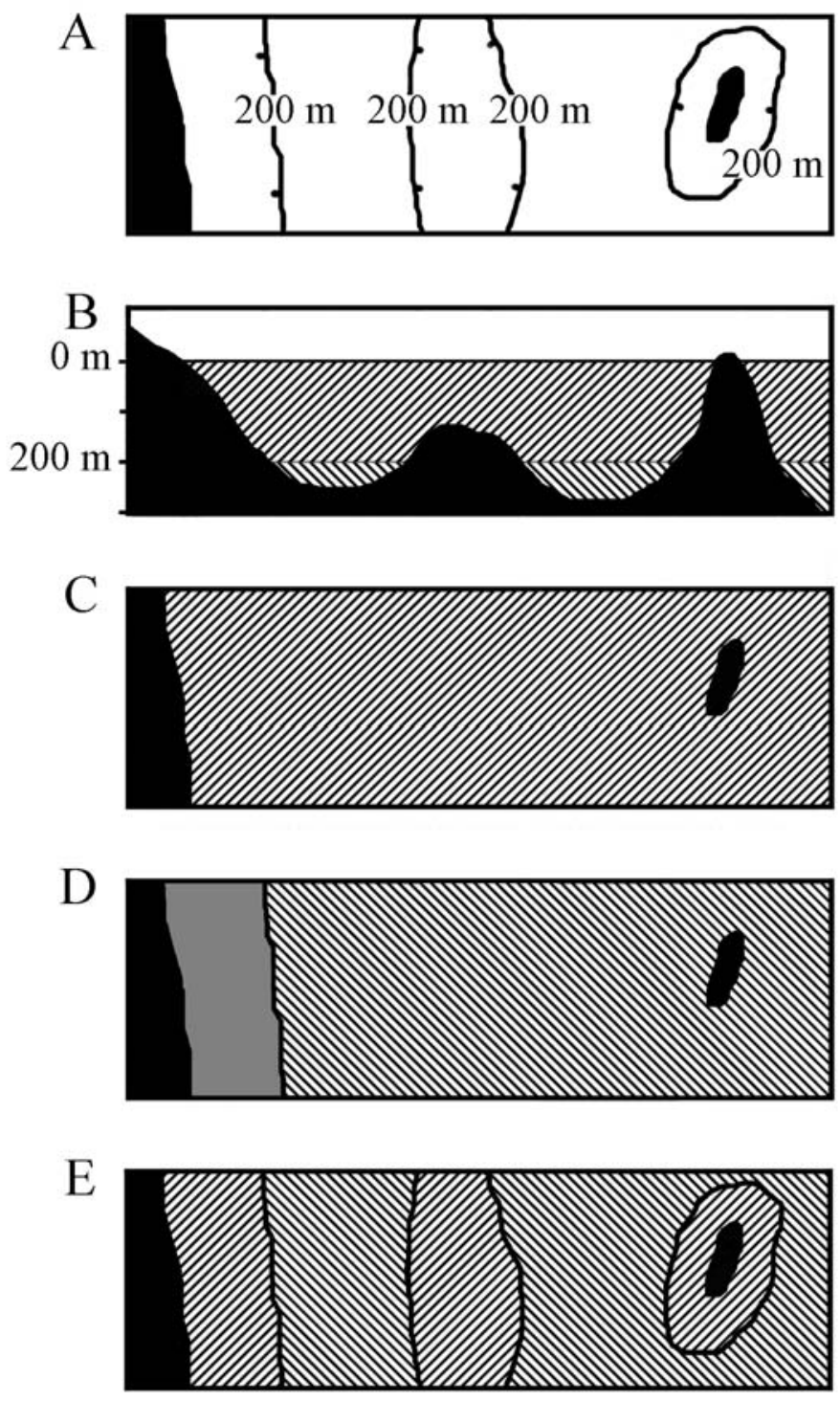

Fig. 4. Cartographic presentation of biotic provinces situated in different vertical zones.

A - bathymetric map of the area including $200 \mathrm{~m}$ isobathes; B - vertical section with indication of bathymetric position of sublittoral and upper-bathyal biotic provinces; $\mathrm{C}-\mathrm{D}$ - correct version of cartographic presentation when only one sublittoral province (C) or one upper-bathyal province (D) is projected on the horizontal plane; E - incorrect version of cartographic presentation when both sublittoral and upper-bathyal biotic provinces are projected on the horizontal plane.

Рис. 4. Картографическая презентация биотических провинций, расположенных в разных вертикальных зонах.

А - батиметрическая карта района с указанием изобат 200 м; В - вертикальный разрез с указанием батиметрического положения сублиторальной и верхнебатиальной биотических провинции; $\mathrm{C}-\mathrm{D}$ - правильные варианты картографической презентации, когда на одну горизонтальную плоскость спроецирована только сублиторальная провинция (C) или одна верхнее-батиальная провинция (D); Е - неверный вариант картографической презентации, когда на одну горизонтальную плоскость спроецированы одновременно сублиторальная и верхнебатиальная биотические провинции. 
Table 1. Main differences between biotic, biocenotic and landscape approaches to biogeographic regionalization.

Таблица 1. Главные различия между биотическим, биоценотическим и ландшафтным подходами к биогеографическому районированию.

\begin{tabular}{|c|c|c|c|}
\hline \multirow{2}{*}{ Basic concepts } & \multicolumn{3}{|c|}{ Application of basic concepts in different approaches } \\
\hline & Biotic & Biocenotic & Landscape \\
\hline $\begin{array}{l}\text { Spatial } \\
\text { manifestation of } \\
\text { a species }\end{array}$ & $\begin{array}{l}\text { Single area (uninterrupted, } \\
\text { continuous species range) }\end{array}$ & $\begin{array}{l}\text { Several areas (interrupted } \\
\text { species range) }\end{array}$ & $\begin{array}{l}\text { Several areas } \\
\text { (interrupted species } \\
\text { range) }\end{array}$ \\
\hline $\begin{array}{l}\text { Main conceptual } \\
\text { categories }\end{array}$ & $\begin{array}{l}\text { Concepts related to } \\
\text { compositions of species }\end{array}$ & $\begin{array}{l}\text { Concepts related to } \\
\text { totality of living } \\
\text { organisms and } \\
\text { compositions of species }\end{array}$ & $\begin{array}{l}\text { Concepts related to } \\
\text { totality of living } \\
\text { organisms and } \\
\text { compositions of } \\
\text { species }\end{array}$ \\
\hline $\begin{array}{l}\text { Relative } \\
\text { importance of } \\
\text { species for } \\
\text { regionalization }\end{array}$ & $\begin{array}{l}\text { Species are equally } \\
\text { important }\end{array}$ & $\begin{array}{l}\text { Species importance differs } \\
\text { in respect to abundance, } \\
\text { biomass etc. }\end{array}$ & $\begin{array}{l}\text { Species importance } \\
\text { differs in respect to } \\
\text { abundance, biomass } \\
\text { etc. }\end{array}$ \\
\hline $\begin{array}{l}\text { Physical- } \\
\text { chemical } \\
\text { parameters of } \\
\text { environment }\end{array}$ & $\begin{array}{l}\text { Excluded from consideration } \\
\text { at initial stage of } \\
\text { regionalization (though } \\
\text { considered at the stage of } \\
\text { casual analysis and at } \\
\text { ecosystem level as } \\
\text { characteristics of } \\
\text { biogeocomplexes) }\end{array}$ & $\begin{array}{l}\text { Excluded from } \\
\text { consideration at initial } \\
\text { stage of regionalization } \\
\text { (though considered at the } \\
\text { stage of casual analysis } \\
\text { and at ecosystem level as } \\
\text { characteristics of } \\
\text { biogeocenoses) }\end{array}$ & $\begin{array}{l}\text { Considered at initial } \\
\text { stage of } \\
\text { regionalization }\end{array}$ \\
\hline Main analysis & Areographic analysis & Cluster analysis & $\begin{array}{l}\text { Physical- } \\
\text { geographical analysis }\end{array}$ \\
\hline $\begin{array}{l}\text { Main criterion } \\
\text { of } \\
\text { biogeographic } \\
\text { boundary } \\
\end{array}$ & $\begin{array}{l}\text { Crowding of species range } \\
\text { limits }\end{array}$ & $\begin{array}{l}\text { Difference between local } \\
\text { (small) biotas }\end{array}$ & $\begin{array}{l}\text { Sharp gradients of } \\
\text { physical-chemical } \\
\text { parameters }\end{array}$ \\
\hline $\begin{array}{l}\text { Small/large } \\
\text { scales }\end{array}$ & Large scales only & From small to large scale & $\begin{array}{l}\text { From small to large } \\
\text { scale }\end{array}$ \\
\hline
\end{tabular}

Biotic boundaries coincide with sharp gradients of physical-chemical parameters of the environment. Nevertheless, the biotic boundaries are revealed, irrespective of environmental characteristics. A strict division of a study into chorological (areographic) and cause-andeffect analyses is an important peculiarity of the biotic biogeography. The lack of an independent chorological stage in many modern biogeographical studies results in the failure of correct causal analysis of the revealed distribution patterns. For example, it is useless estimating coincidence of biotic boundaries along sharp gradients of physical-chemical parameters of the environment, if the latter were used in revealing of the formers.

To distinguish the biotic approach to regionalization from the biocenotic and landscape ones, seven characters have been selected (Table 1). Treatment of a species range as a conti-

nuity is the main difference of the biotic approach. This concept allows retaining entity of a species as a minimum biological object of investigation and analysis at a global scale. Areographical analysis is used in the biotic approach, the biocenotic approach is often based on the cluster analysis. The biotic approach adopts the assumption of a continuity of a species range, whereas in the biocenotic approach a species range is considered as interrupted. Environmental data are excluded in these two approaches. The use of environmental data at the initial stage of regionalization is considered as the main distinguishing character of purely landscape biogeography opposed to biotic and biocenotic approaches. Table 2 shows importance of data on geological environment in landscape studies. In the biocenotic and landscape approaches there is gradual transition from small units to larger ones, whereas the biotic 
Table 2. Main criteria for separating landscape regions and typological complexes in the Laptev Sea (after Gukov, 1999, with small changes based on personal communications of Gukov).

Таблица 2. Основные критерии выделения ландшафтных регионов и типологических комплексов в море Лаптевых (по Гукову (1999) с небольшими изменениями на основании устных сообщений

Гукова).

\begin{tabular}{|l|l|l|}
\hline Classification unit & \multicolumn{1}{|c|}{ Main criterion for separation } & \multicolumn{1}{c|}{ Examples } \\
\hline Country & $\begin{array}{l}\text { Geostructural position (morphostructure of } \\
\text { higher order (Milkov, 1970) }\end{array}$ & Laptev Sea \\
\hline Province & $\begin{array}{l}\text { Geological-morphological peculiarities } \\
\text { defined by tectonic structures }\end{array}$ & $\begin{array}{l}\text { West Laptev Marine } \\
\text { Province }\end{array}$ \\
\hline Area & Geological-morphological peculiarities & West Laptev Coastal Area \\
\hline \multicolumn{3}{|c|}{ Typological (repetitive) landscape complexes } \\
\hline Landscape & $\begin{array}{l}\text { Hydro-meteorological in combination with } \\
\text { geomorphological }\end{array}$ & $\begin{array}{l}\text { Landscape of underwater } \\
\text { river valleys }\end{array}$ \\
\hline Area & $\begin{array}{l}\text { Lithologic-facial-geomorphological in } \\
\text { combination with hydrobiological }\end{array}$ & $\begin{array}{l}\text { Area of muddy-silt valley } \\
\text { slopes }\end{array}$ \\
\hline Facies & Hydobiological & $\begin{array}{l}\text { Facies of sandy areas with } \\
\text { Mya truncata community }\end{array}$ \\
\hline
\end{tabular}

approach considers only large territorial units.

Any concept related to the totality of living organisms is useless for biogeographical regionalization based on the species approach. Moreover such concepts are prohibited in species biogeographical regionalization (synonyms - biotic, or historical regionalization), since they create the confusion of approaches (Beklemishev, 1982; Chernov, 1984).

The present work is mainly based on results of the chorological analysis of species distributions in the Arctic Ocean. Results of the causeand-effect analysis are only briefly considered in the last three sections (9-11). Causal analysis in biotic biogeography is not unique, its aims and methods overlap with those applied in macroecology. To make a transition to the causeand-effect analysis it was critical to use a category related to totality of living organisms. Mironov $(1987,1990,2004,2012)$ used for this reason the term "biotic complex". According to Mironov, the "biotic complex" is the totality of living organisms, the biota, inhabiting an area outlined by zones of crowding of species range limits. A biotic complex, together with a biogeographic (biotic) region, is considered as a large ecosystem or biogeocomplex. In the ecosystem approach, the biotic complex is viewed as a multitude of communities (=biocenoses) integrated into a biological system. In earlier publications (for review see Semenov, 1986; Mironov, 2004) the terms "floristic complex" or "faunistic complex" were defined as a set of species.
The biotic complex is the totality of living organisms, from Bacteria and Archaea to Animalia. The distributions patterns of Bacteria, Archaea and Protista may not correspond to biotic boundaries revealed based on larger organisms. The notion of the biotic complex has been modified to "bridge" chorological (biotic regionalization, biotic regions) and ecological data, to make a transition to studies of large ecosystems (biogeocomplexes). These large ecosystems include the totality of all living organisms.

A boundary between two adjacent shallowwater biotic regions in horizontal projection can coincide with that between shallow-water and deep-water biotic regions, as shown on Fig. 5. A territory occupied by one benthic biotic complex cannot harbour a second benthic biotic complex. Species from different benthic complexes coexist only in crowding zones. At the same time, the space of a benthic biotic complex overlaps with the space of a pelagic complex. The former thus is inhabited by pelagic animals, although these are not members of a benthic biotic complex.

Tansley (1935) first applied the term "ecosystem" and suggested its two main features: the integration of living organisms and the environment, and ability of a vegetation unit (part of the ecosystem) to self-reproduction in the course of succession. The concept of "biogeocenosis" of Sukachev (1964) had a similar meaning. Odum (1975) considered ecosystem and biogeoceno- 
Table 3. Bathymetric position of boundaries between vertical biotic or biocenotic/landscape zones in the Arctic Ocean. Intertidal (littoral) zone is omitted. Таблица 3. Батиметрическое положение границ между вертикальными биотическими или ландшафтно-биоценотическими зонами в Северном Ледовитом океане: обзор публикаций. Литоральная зона упущена из рассмотрения.

\begin{tabular}{|c|c|c|}
\hline Geographical regions & Bathymetric position of boundaries, $\mathrm{m}$ & References \\
\hline \multicolumn{3}{|c|}{ Benthic fauna } \\
\hline $\begin{array}{l}\text { Kola Peninsula and White } \\
\text { Sea }\end{array}$ & $80-90,180-200$ & Herzenstein, 1885 \\
\hline Norwegian Sea & $30-40,150,600-800,2000$ & Appellöf, 1912 \\
\hline Kola Bay & $55-65,180-230$ & Deryugin, 1915 \\
\hline Laptev Sea & $900-1100$ & Gorbunov, 1946 \\
\hline $\begin{array}{l}\text { North of Svalbard and } \\
\text { Frantz Josef Land }\end{array}$ & $1100-1800$ (wide transition zone) & Koltun, 1964 \\
\hline Western Barents Sea & $100,200-500$ & Filatova, 1957 \\
\hline Arctic Ocean & $12,360-425,570-610,869-1000$ & Menzies et al., 1973 \\
\hline Western Beaufort Sea & 300 & Bilyard, Carey, 1980 \\
\hline White Sea & $10,80,240$ & Fedyakov, 1980 \\
\hline Southwest Norway & $1000-1200,1400,2000,2600-3000$ & Mackensen et al., 1985 \\
\hline Eastern Norwegian Sea & $900-1300$ & Jirkov, Mironov, 1985 \\
\hline $\begin{array}{l}\text { Norwegian and Greenland } \\
\text { basins }\end{array}$ & 2500 & Fedyakov, Naumov, 1989 \\
\hline Central Arctic basins & $200-500$ & Fedyakov, Naumov, 1989 \\
\hline $\begin{array}{l}\text { Deep Norwegian and } \\
\text { Greenland Seas }\end{array}$ & $\begin{array}{l}800-1000 \text { (cumulative number of first } \\
\text { occurrences of species) }\end{array}$ & Svavarsson et al., 1990 \\
\hline $\begin{array}{l}\text { Deep Norwegian and } \\
\text { Greenland Seas }\end{array}$ & $\begin{array}{l}800-1000,1500,2000 \text { (clusters of } \\
\text { stations) }\end{array}$ & Svavarsson et al., 1990 \\
\hline Arctic Ocean & $200,800,1200$ & Golikov et al., 1990 \\
\hline $\begin{array}{l}\text { The Norwegian fiords, } \\
\text { White Sea and eastern } \\
\text { parts of the Barents Sea }\end{array}$ & $\begin{array}{l}30-40 \text { (the border between the Atlantic } \\
\text { Boreal and the Arctic Regions) }\end{array}$ & Golikov et al., 1990 \\
\hline Norwegian Sea & $150-200,600-800,1000-1200$ & Krayushkina, 2000 \\
\hline $\begin{array}{l}\text { Near Atlantic sector of the } \\
\text { Arctic Ocean }\end{array}$ & 1000 & Dinter, 2001 \\
\hline Spitsbergen & $370-500,1500-2000$ & $\begin{array}{l}\text { Wlodarska-Kowalczuk et } \\
\text { al., } 2004\end{array}$ \\
\hline $\begin{array}{l}\text { Arctic Ocean (excluding } \\
\text { Norwegian Sea) }\end{array}$ & 500 & Jirkov, 2010 \\
\hline \multicolumn{3}{|c|}{ Zooplankton } \\
\hline Central Arctic & $510-619,1142-1532,2000-2250$ & Green, 1959 \\
\hline NE Baffin Sea & $50(? 150,250)$ & Buhanan, Sekerak, 1982 \\
\hline Arctic Basins & $50,100,500,2000$ & $\begin{array}{l}\text { Kosobokova, Hirche, } \\
\text { 2000; Kosobokova, } \\
\text { Hopcroft, } 2010\end{array}$ \\
\hline
\end{tabular}

sis as synonyms. According to UNESCO recommendations of 1965 (Copenhagen Symposium), biogeocenosis is a particular case of an ecosystem. The definition of ecosystem proposed by Evans (1956) appeared to be wider. He considered "ecosystem" absolutely "non dimensional", designating any supraorganismal living system interacting with the environment. This concept focuses on processes and functions of a system and its ability to function, which is not related to limits of the system itself. Such an approach agrees with the general theory of systems. However, the abandonment of the initial and rather operational concept of "ecosystem", suggested by Tansley (1935), undoubtedly hampered studies of spatially separated structuralfunctional units of the biosphere.

In the present study the term "ecosystem" is used in the meaning of Tansley (1935). The existence of biogeocomplexes was suggested 


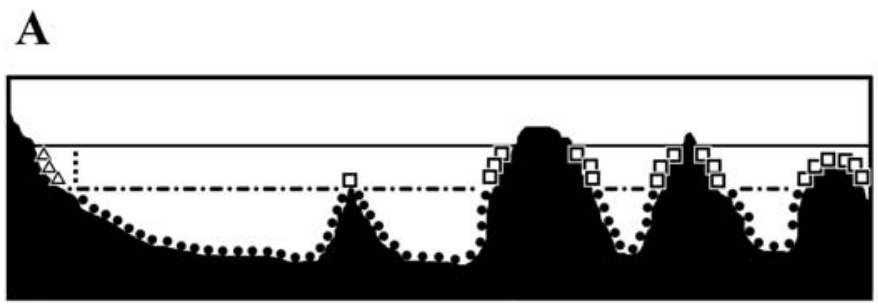

B

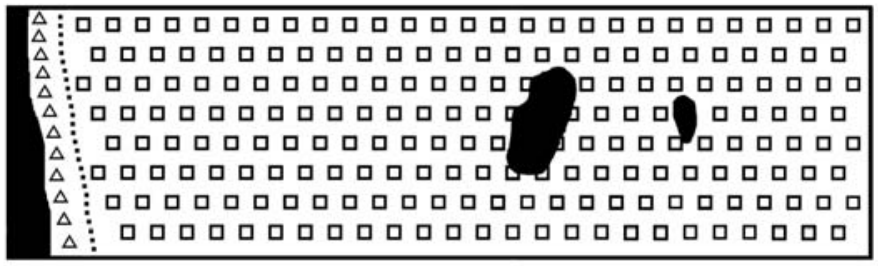

C
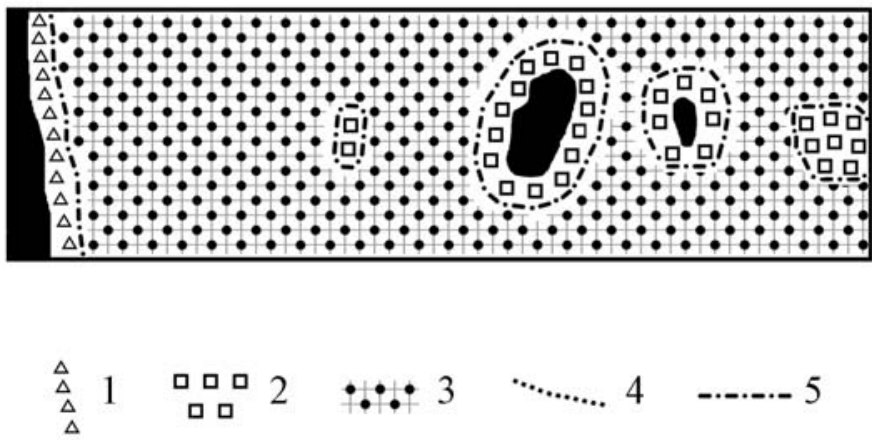

Fig. 5. Coincidence of two different biotic boundaries projected on one horizontal plane.

A - vertical section of the area with the vertical position of three biotic provinces; B - correct version of cartographic presentation when only sublittoral provinces are projected on the horizontal plane; $\mathrm{C}$ - incorrect version of cartographic presentation when both sublittoral and upper-bathyal biotic provinces are projected on the horizontal plane. The boundary between near-continental and open-oceanic sublittoral provinces completely coincides on the projection with the boundary between near-continental sublittoral and bathyal provinces.

1 - near-continental sublittoral province, 2 - open-oceanic sublittoral province, 3 - bathyal province, 4 - boundary between near-continental and open-oceanic sublittoral provinces, 5 - boundary between near-continental and bathyal provinces.

Рис. 5. Совпадение двух разных биотических границ, спроецированных на одну горизонтальную плоскость.

А - вертикальный разрез района с указанием расположения по вертикали трех биотических провинций; В правильный вариант картографической презентации, когда на одну горизонтальную плоскость спроецированы только сублиторальные провинции; С - неверный вариант картографической презентации, когда на одну горизонтальную плоскость спроецированы одновременно сублиторальные и верхнебатиальная биотические провинции. Граница между приконтинентальной и открыто-океанической сублиторальными провинциями полностью совпадает на проекции с границей между приконтинентальной сублиторальной и батиальной провинциями.

1 - приконтинентальная сублиторальная провинция, 2 - открыто-океаническая сублиторальная провинция, 3 - батиальная провинция, 4 - граница между приконтинентальной и открыто-океанической сублиторальными провинциями, 5 - граница между приконтинентальной и батиальной провинциями. 


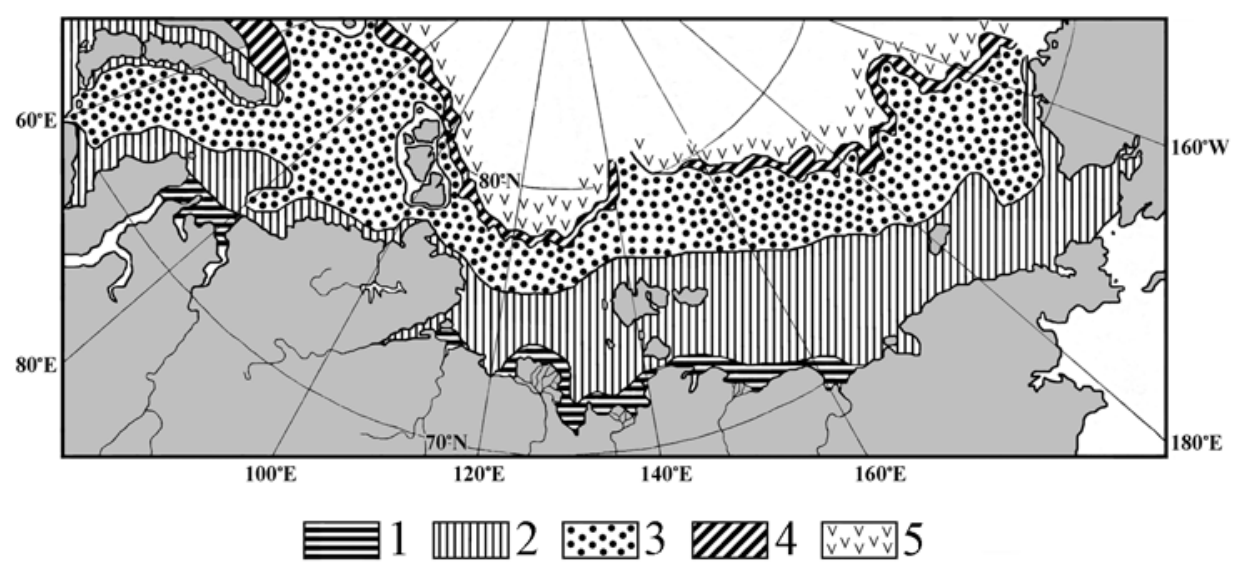

Fig. 6. Diagram of the distribution of the main groups of benthic communities in the Russian Arctic seas (modified after Sirenko, 1998).

Dominating groups: 1 - isopod Saduria entomon, ascidian Rhizomolgula globularis, bivalves Portlandia aestuariorum and Cyrtodaria kurriana (estuarine belt); 2 - bivalves Astarte borealis, A. montagui, Macoma calcarea, Nuculana pernula, N. radiata, Ennucula tenuis, Portlandia arctica, P. siliqua, Astarte crenata, Yoldia hyperborean and Ciliatocardium ciliatum; 3 - ophiuroids Ophiocten sericeum, Ophiacantha bidentata, Ophiopleura borealis and others; 4 - polychaetes of the families Maldanidae, Chaetopteridae and others; 5 - echinoderms Elpidia glacialis, Kolga hyalina and Pourtalesia jeffreysi.

Рис. 6. Схема распределения основных групп донных сообществ в российских морях Северного Ледовитого океана. (Модифицировано по Сиренко, 1998).

Доминирующие группы донных животных: 1 - изопода Saduria entomon, асцидия Rhizomolgula globularis, двустворчатые моллюски Portlandia aestuariorum, Cyrtodaria kurriana (эстуарный пояс); 2 - двустворчатые моллюски Astarte borealis, A. montagui, Macoma calcarea, Nuculana pernula, N. radiata, Ennucula tenuis, Portlandia arctica, P. siliqua, Astarte crenata, Yoldia hyperborean, Ciliatocardium ciliatum; 3 - офиуры Ophiocten sericeum, Ophiacantha bidentata, Ophiopleura borealis и другие; 4 - полихеты семейств Maldanidae, Chaetopteridae и другие; 5 - иглокожие Elpidia glacialis, Kolga hyalina, Pourtalesia jeffreysi.

based on coincidence of biotic boundaries with boundaries of other kinds: geomorphological, hydrological, productional etc. (Mironov, 1990, 1999) and on organization of communities of biotic complexes into succession systems (Mironov, 2004). Succession system is a group of communities with similar gradual, predictable changes taking place in structure of the communities of given area over time. Communities of the succession system differ from each other since they are at different stages of ecological succession. The coincidence of biogeographic boundaries with boundaries of succession ("cenotic") systems was suggested by Razumovsky (1999). However, the organization of communities of biogeographic regions into succession systems is still not sufficiently supported by complex investigations that should include detailed successional and biogeographic studies of the same area.

\section{Vertical biogeographical zones}

The various depths of biogeographic boundaries in the Arctic Ocean are summarized in Table 3. Most of these boundaries were identified using community, landscape or mixed approaches. Community and landscape criteria were used both explicitly and implicitly. Golikov and Scarlato (1989: 268) for example, explicitly applied the landscape criteria, having suggested that the Atlantic-Arctic Intermediate waters extend between $200-400$ and $650-1000$ $\mathrm{m}$, with a temperature of $1.3-2.3^{\circ} \mathrm{C}$ and salinity $35 \%$ forming a separate province. Kosobokova with co-authors (Kosobokova, Hirche, 2000; Kosobokova, Hopcroft, 2010) followed the biocenotic approach. These authors recognized four vertical zones in the Central Arctic (Table 3), differing in the abundance of particular species in planktonic communities. Changes in species com- 


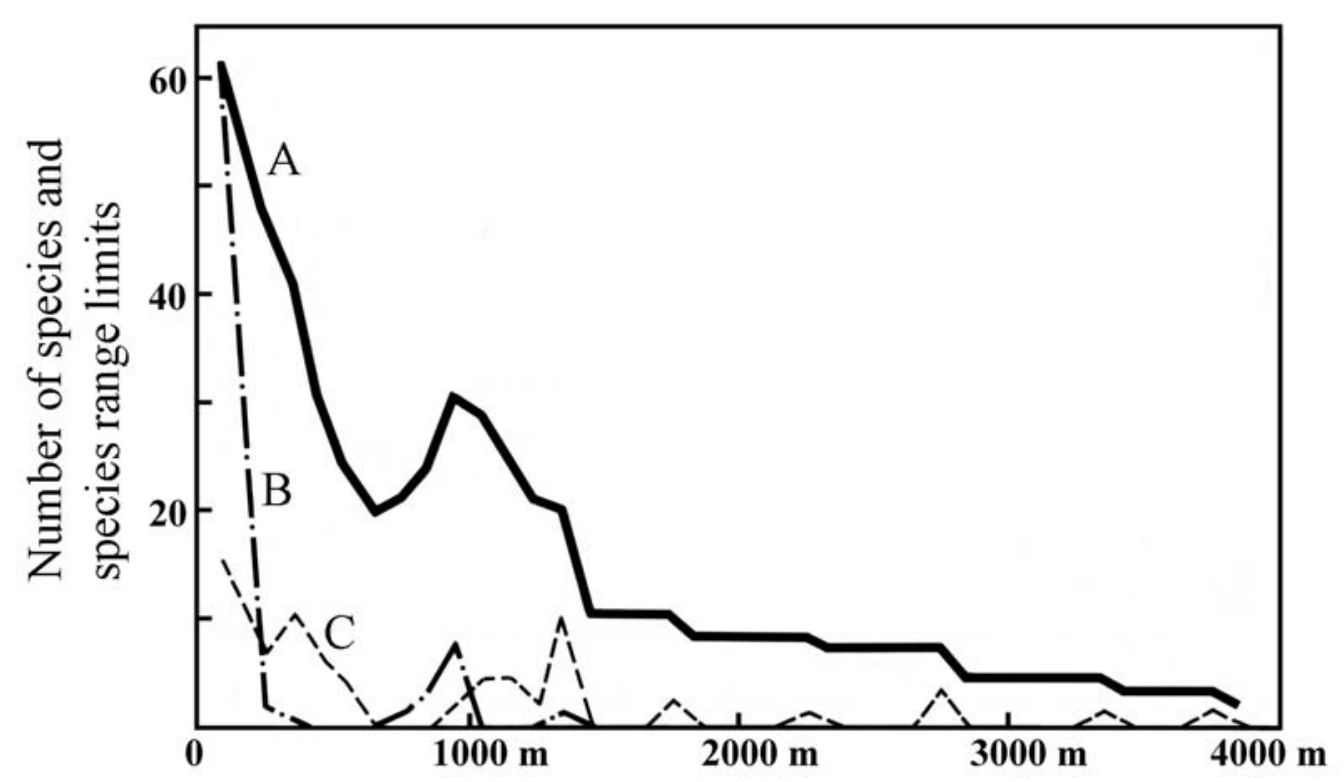

Fig. 7. Vertical distribution of polychaetes off Norway (after Jirkov, Mironov, 1985).

A - number of species; B - number of upper limits of species ranges; C - number of lower limits of species ranges. Рис. 7. Распределение по вертикали полихет в районе Норвегии (из Жиркова и Миронова, 1985).

А — число видов; В — число верхних границ видовых ареалов; С — число нижних границ видовых ареалов.

position with depth alone do not indicate distinct bathymetrical zones. Sirenko (1998) reduced the number of various benthic communities in the Arctic Ocean to a few main types differing by the set of prevailing and most characteristic species. Fig. 6 shows the distribution of six types of communities in the Kara, Laptev, East Siberian and Chukchi Seas. The map illustrates vertical zonality in areas occupied by these communities. Zones follow the coast and slope of Eurasia and change with increasing depth.

Vertical zones are often revealed by cluster analysis. For example, faunas (species lists) of sampling localities or bathymetric intervals are compared and faunal homogeneity or distinctiveness is expressed as indices of faunal similarity (Menzies et al., 1973; Svavarsson et al., 1990; Brandt, 1997; Wlodarska-Kowalczuk et al., 2004; Jones et al., 2007). This method does not follow the main assumption of biotic biogeography, the continuity of a species range. It reveals boundaries that can be both biocenotic and biotic.

Vertical faunistic species boundaries were detected reliably only in the Norwegian Sea
(Jirkov, Mironov, 1985; Svavarsson et al., 1990; Krayushkina, 2000). Jirkov and Mironov (1985) examined vertical faunistic transects of the polychaete fauna in the eastern Norwegian Sea. The study area was divided into equal bathymetric intervals. For each interval the number of species range limits was estimated and plotted against depth (Fig. 7). This number peaked at depths of 900-1200 m. An increase in species richness occurred at the same depth. A similar method was applied by Krayushkina (2000) for the fauna of sea stars and holothurians of the entire Norwegian Sea. Three weakly expressed crowding zones were found: at 150-200, 600800 and 1000-1200 m. Svavarsson et al. (1990) used both the faunistic (implying the species range continuity) and biocenotic approaches in the study of distribution of isopods. The faunistic component was present in the method of "accumulation curves", when species boundaries (upper limits of species vertical distribution) were summed with increasing depth. The cumulative number of the first occurrences of isopod species clearly increased at depths 800$1000 \mathrm{~m}$. A high rate of species replacement at 


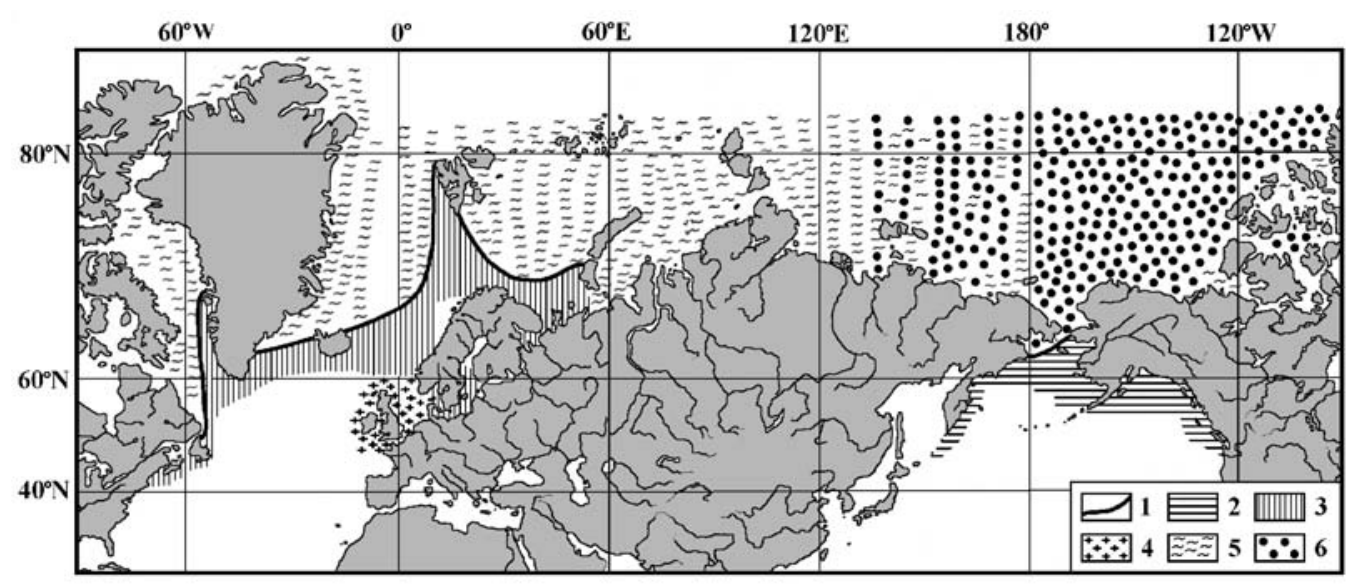

Fig. 8. Biogeographic division of the Arctic Ocean and adjacent areas based on the distribution of gastropods Buccinidae (after Golikov, 1980).

1 - boundary between the Arctic Region and the Pacific Boreal and Atlantic Boreal Regions, 2 - Aleutian High Boreal Subregion, 3 - Norwegian High Boreal Province, 4 - Celtic Low Boreal Province, 5 - West Arctic Province, 6 East Arctic (Chukchi-American) Province.

Рис. 8. Биогеографическое районирование Северного Ледовитого океана и смежных районов на основе распространения брюхоногих моллюсков семейства Buccinidae (модифицировано по Голикову, 1980).

1 - граница между Арктической Областью и Тихоокеанской Бореальной и Атлантической Бореальной Областями, 2 - Алеутская Высокобореальная Подобласть, 3 - Норвежская Высокобореальная Провинция, 4 - Кельтская Низкобореальная Провинция, 5 - Западноарктическая Провинция, 6 - Восточноарктическая (Чукотско-Американская) Провинция.

depths $800-1000 \mathrm{~m}$ was supported by the chisquare test modified by Gardiner and Haedrich (1978). Cluster analysis revealed additional boundaries at 1500 and $2000 \mathrm{~m}$, however this approach is not biotic.

\section{Species (biotic) regionalization}

\subsection{Shelves}

Biogeographical schemes with only two or three subdivisions of the entire Arctic shelf are usually based on the biotic approach. In schemes with two subdivisions, the single boundary passes through the Norwegian Sea or through both the Norwegian and Barents Seas (Heptner, 1936; Ekman, 1953; Hedgpeth, 1957; De Lattin, 1967; Briggs, 1974, 1995; Vassilenko, 1974; Boltovskoy, Wright, 1976; Kussakin, 1979; Andriyashev, Shaposhnikov, 1985; Gontar, Denisenko, 1989; Mecklenburg et al., 2010; Chernova, 2011). This boundary separates the large Arctic subdivision (region, subregion or province) from the northern section of the Arctic-North Atlan- tic subdivision. Thus, Briggs $(1974,1995)$ drew the boundary in the Norwegian Sea (north of Kola Fjord) based on the most northern and southern occurrences of species This boundary separates the Arctic Region from the East Atlantic Region. The Arctic Region extends out from the Arctic Ocean into the North-West Atlantic and the North Pacific, whereas the East Atlantic Region extends out from the Atlantic Ocean into the Norwegian and Barents Seas (Fig. 1).

In schemes with two boundaries (with three subdivisions), the second boundary passes either in the southern Chukchi Sea or in the high Arctic. The boundary in the Chukchi Sea delimits the Arctic and the North Pacific Regions (Hedgpeth, 1963; Grainger, 1966; Pavshtiks, 1985). The boundary in the high Arctic passes across the Arctic Ocean from the East-Siberian Sea to the Canadian Archipelago. It divides the Arctic Region into two large Arctic provinces (Golikov, 1980; Mironov, Dilman, 2010) (Fig. 8). In some schemes, with more than three Arctic subdivisions, a similar boundary is present (Nesis, 1982, 1987; Golikov, Scarlato, 1989; 
Golikov et al., 1990). There are several names for the two large provinces: the Western Arctic and Eastern Arctic (Golikov, 1980), Eurasian and Amerasian (Golikov et al., 1990), Western Siberian and Chukchi-Canadian (Nesis, 1982, 1987), Siberian and Chukchi-American (Gurjanova, 1951). In the present study they are named the American-Eurasian and ChukchiAmerican Provinces.

The generalized biotic scheme of the Arctic shelf and upper slope is shown on Figure 9. The Shelf-Upper Slope Subregion of the North Polar Region is suggested to have a lower depth at $800 \mathrm{~m}$ and crowding zone at $800-1200 \mathrm{~m}$. The crowding zone was only reliably detected at $800-1200 \mathrm{~m}$ in the Norwegian Sea (see section $4)$. The position of the boundary between the shallow-water and deep-sea biogeographical regions is unknown in the other Arctic seas. Therefore the lower boundary of the ShelfUpper Slope Subregion is conventional.

The Shelf-Upper Slope Subregion corresponds approximately to the Arctic Region or the Arctic Subregion in many earlier biogeographical schemes (e.g. Ortmann, 1896; Schmidt, 1904; Heptner, 1936; Gurjanova, 1951; Ekman, 1953; Filatova, 1957, 1962; Zenkevitch, 1963a, b; De Lattin, 1967; Briggs, 1974, 1995; Vassilenko, 1974; Kussakin, 1979; Golikov, 1980; Nesis, 1982; Pavshtiks, 1985; Tsvetkova, 1985; Golikov, Scarlato, 1989; Gontar, Denisenko, 1989) (Figs. 8, 10, 11, 12). The term "Arctic" has many meanings including the geographic, zonal and ecological (cold-water species) (see Jirkov, present volume). To avoid the notional confusion in using this term, the large biogeographic region of the Arctic Ocean is designated here as the North Polar. The North Polar ShelfUpper Slope Subregion is divided into the American-Eurasian and Chukchi-American Provinces occupying most of the Arctic shelf. The ranks of the subdivisions are given arbitrarily, without special biogeographic ranking analysis (see section 5.2).

Some other boundaries on the shelf require confirmation. Brattegard and Holthe (1997) recognized two boreal subdivisions on the western Norwegian shelf, whereas Krayushkina (2000) and Dilman (2009) showed three boreal subdivisions in this area. The crowding zones between these subdivisions are apparently related to the stepwise reduction in boreal species num- ber in northward. The White Sea biota probably is also separated by the crowding zone related to a drastic reduction in species number. Filatova (1962) and Jirkov, Leontovich (2012) distinguished the littoral (or shallow-water), sublittoral (or shelf) and bathyal (or low sublittoralupper bathyal) Arctic provinces. Vertical biotic transects are required to confirm crowding zones within the depth range from 0 to $800 \mathrm{~m}$.

The generalized biotic scheme of the Arctic shelf is based on the distribution patterns of benthic and pelagic invertebrates and fishes. Zinova (1985) used data on the distribution of benthic algae. Her biogeographical scheme was based on the mixed approach (see Section 8.1). No purely Arctic species of planktonic dinoflagellates and diatoms were discovered. For this reason, the unity of the arctic-boreal phytogeographical zone was suggested for the pelagic realm(Okolodkov, Dodge, 1996; Semina, 1997; Okolodkov, 1999). However the southern boundary of the Arcto-Boreal Region (Semina, 1997, Fig. 23) coincides with the southern border of the crowding zone outlining the North Polar Region in the North-West Atlantic and Iceland areas (Fig. 9).

The great width of the biotic boundaries (crowding zones) is one of the most specific characters of the generalized biotic scheme of the Arctic shelf (Fig. 9). However the biotic boundaries in the Arctic Ocean are not always wide. The narrowest crowding zone is found on the shelf (as well as on the slope) of Iceland. The biogeographic boundary divides the Icelandic shelf into the southwest and the northeast sectors (Figs. 8, 10, 11). The number of species occurring on the southern shelf and the upper slope, but unknown from the northern shelf and slope (and vice versa, ) is high. For example, six species of caudofoveates are known in the Exclusive Economic Zone of Iceland, all of them recorded only south of Iceland (Ivanov, Sheltema, 2001). The diversity of the amphipod family Calliopiidae is much higher in the north-east (17 species) than in the south-west ( 5 species) of Iceland, with $72 \%$ of species restricted to only one side of the Greenland-Iceland-Faeroe Ridge (Weisshappel, 2001). Species of the amphipod family Ampeliscidae were grouped according to three geographical patterns: six northern species, nine southern species and four circumIcelandic species (Dauvin et al., 2012). The 


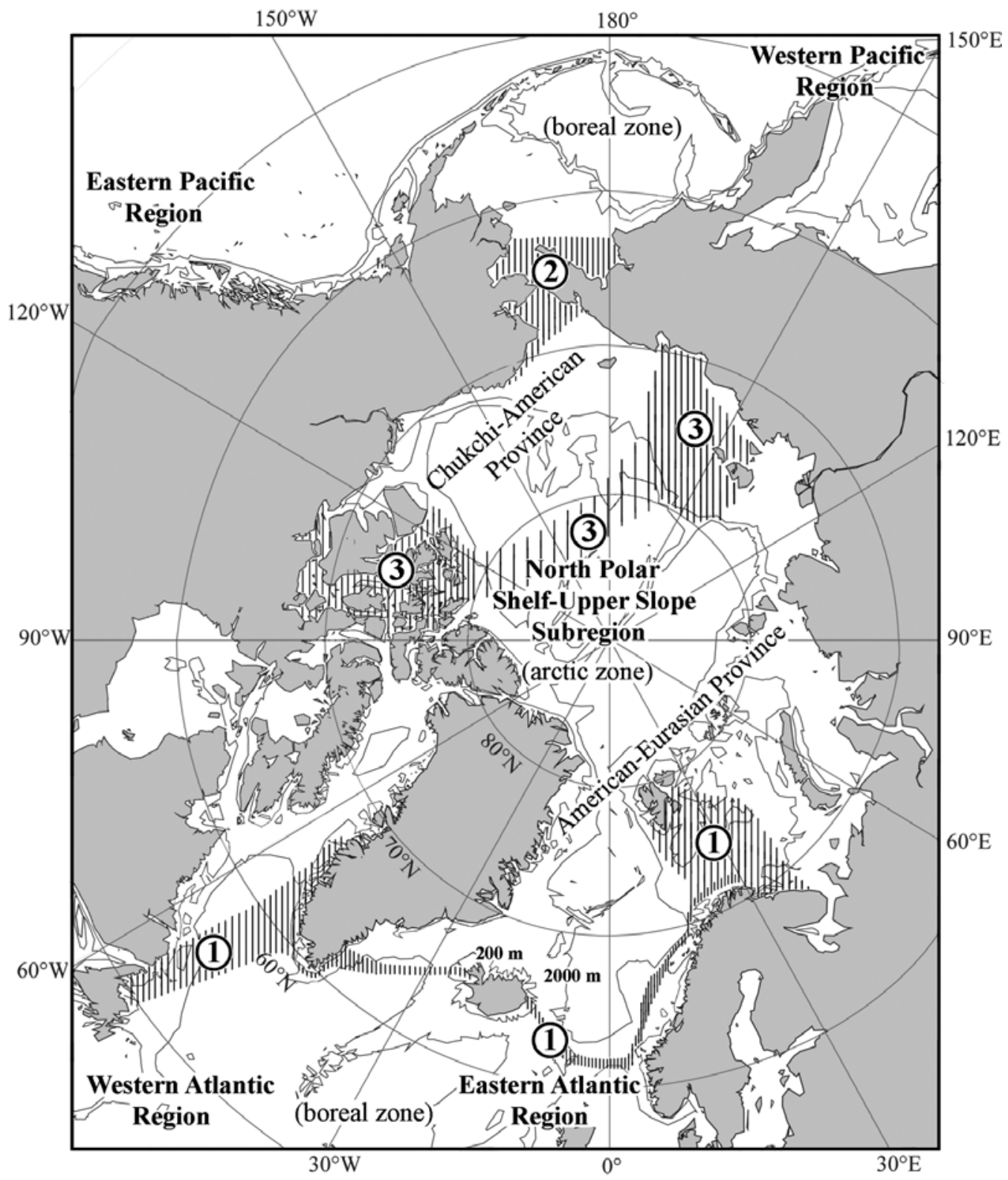

Fig. 9. Shelf-Upper Slope Subregion $(0-800 \mathrm{~m})$ of the North Polar Region based on biotic approach to biogeographic regionalization (generalized scheme).

1 - the boundary between North Polar Region and Easter and Western Atlantic Regions, 2 - the boundary between North Polar Region and Easter and Western Pacific Regions, 3 - the boundary between American-Eurasian Province and Chkchi-American Province. The open-ocean part of this boundary is imitative.

Рис. 9. Шельфовая Верхнебатиальная Подобласть Северной Полярной Области, основанная на биотическом подходе к биогеографическому районированию (генерализованная схема).

1 - граница между Северной Полярной Областью и Восточной и Западной Атлантическими Областями, 2 граница между Северной Полярной Областью и Восточной и Западной Пацифическими Областями, 3 - граница между Американо-Евразийской и Чукотско-Американской Провинциями. Открыто-океаническая часть этой границы является имитационной. 


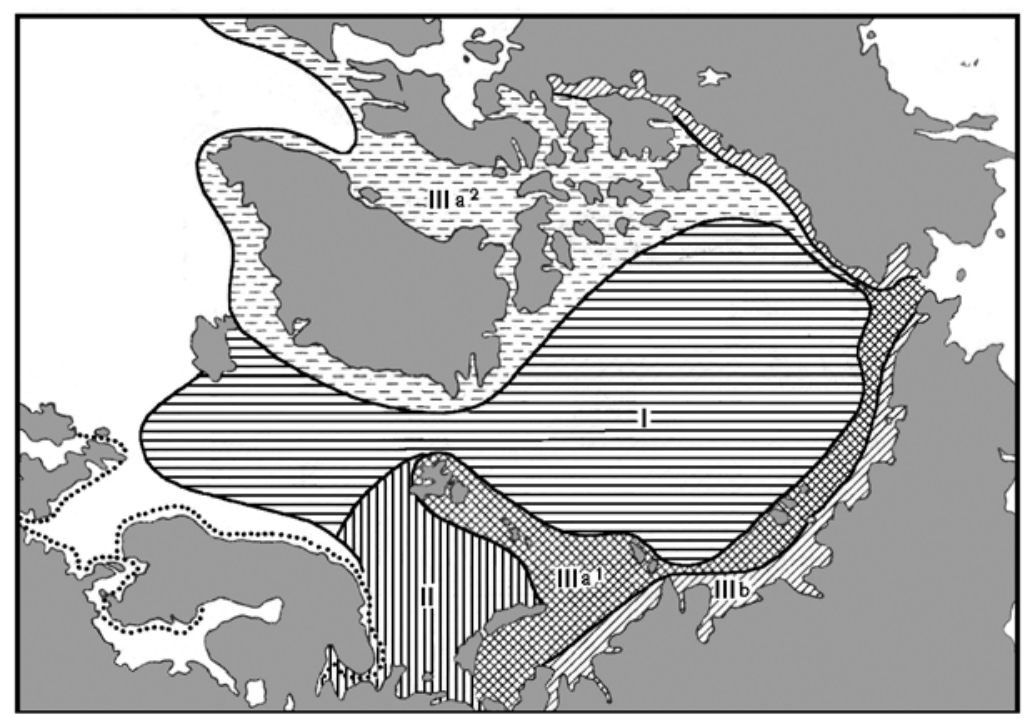

Fig. 10. Biogeographic division of the Arctic Ocean (after Zenkevitch, 1963a).

I - Abyssal Arctic Subregion, II - Low Arctic Shallow Subregion, III — High Arctic Sublittoral Subregion, IIIa Shallow Marine Province, IIIa ${ }^{1}$ - Siberian District, $\mathrm{IIIa}^{2}$ - North American-Greenland District. IIIb - Shallow Brackish-water Province. Propagation of the boreal littoral fauna northwards and eastwards is marked by dotted line. Рис. 10. Биогеографическое районирование Северного Ледовитого океана (по Зенкевичу, 1963a). I - Абиссальная Арктическая Подобласть, II - Нижнеарктическая Мелководная Подобласть, III - Высокоарктическая Мелководная Подобласть, ІІІа - Высокоарктическая Мелководная Морская Провинция, IIIa $^{1}$ Сибирский Район, IIIa ${ }^{2}$ - Северо-Американско-Гренландский Район. IIIb - Высокоарктическая Мелководная Солоноватоводная Провинция. Точечной линией показано распространение на север и восток литоральной бореальной фауны.

isopod families Desmosomatidae and Nannoniscidae are species-rich in Iceland waters: in total 34 species from 20 genera were reported. Most of these species are restricted either to the north (10 species) or the south (14) of the GreenlandIceland-Faeroe Ridge (Brix, Svavarsson, 2010).

The biogeographical schemes of the Arctic shelf with wide biogeographical boundaries are few (Hedgpeth, 1963; Grainger, 1966; Golikov, 1980; Nesis, 1982, 1987; Andriyashev, Shaposhnikov, 1985; Pavshtiks, 1985; Golikov, Scarlato, 1989; Mironov, Dilman, 2010; Chernova, 2011). In most schemes the biogeographical boundary is drawn as a line. A linear boundary between the Arctic and Boreal Regions is placed, by different authors, from the latitude of the Lofoten Islands (Briggs, 1974, 1995) to Spitsbergen and the eastern border of the Barents Sea on the European shelf (Hedgpeth, 1957; Golikov, 1980; Golikov et al., 1990), from the Cape Cod (Forbes, 1856; Woodward, 1866; Gontar, Denisenko, 1989) to the Hudson Strait (Kus- sakin, 1979; Petryashov, 2009) on the shelf of north-eastern America, and from Cape Olutorsky and the Nunivak Island (the western and the eastern Bering Sea respectively) (Briggs, 1974, $1995)$ to Herald Canyon and Point Barrow on the Chukchi Sea shelf (Makarov, 1941; Petryashov, 2002b) (for different versions see Figs. 1, 8, 10-12; other examples in Semenov, 1986, Jirkov, 2013, and Petryashov et al., 2013). If all versions of a linear boundary were mapped, the result would be a crowding zone of lines (see Semenov, 1986, Fig. 22). Wide crowding zones of species range limits nearly coincide with crowding zones of biogeographical linear borders.

The linear boundary in the East Siberian Sea is drawn in the eastern part of the sea, at about $145^{\circ} \mathrm{E}$ by Golikov and Scarlato (1989), or in the central part, at $160-170^{\circ} \mathrm{E}$, by Bogdanov (1994) and Petryashov et al. (2010) or in the eastern part, at $175-180^{\circ} \mathrm{E}$ by other authors (Gurjanova, 1951; Tsvetkova, 1985; Fedyakov, Nau- 


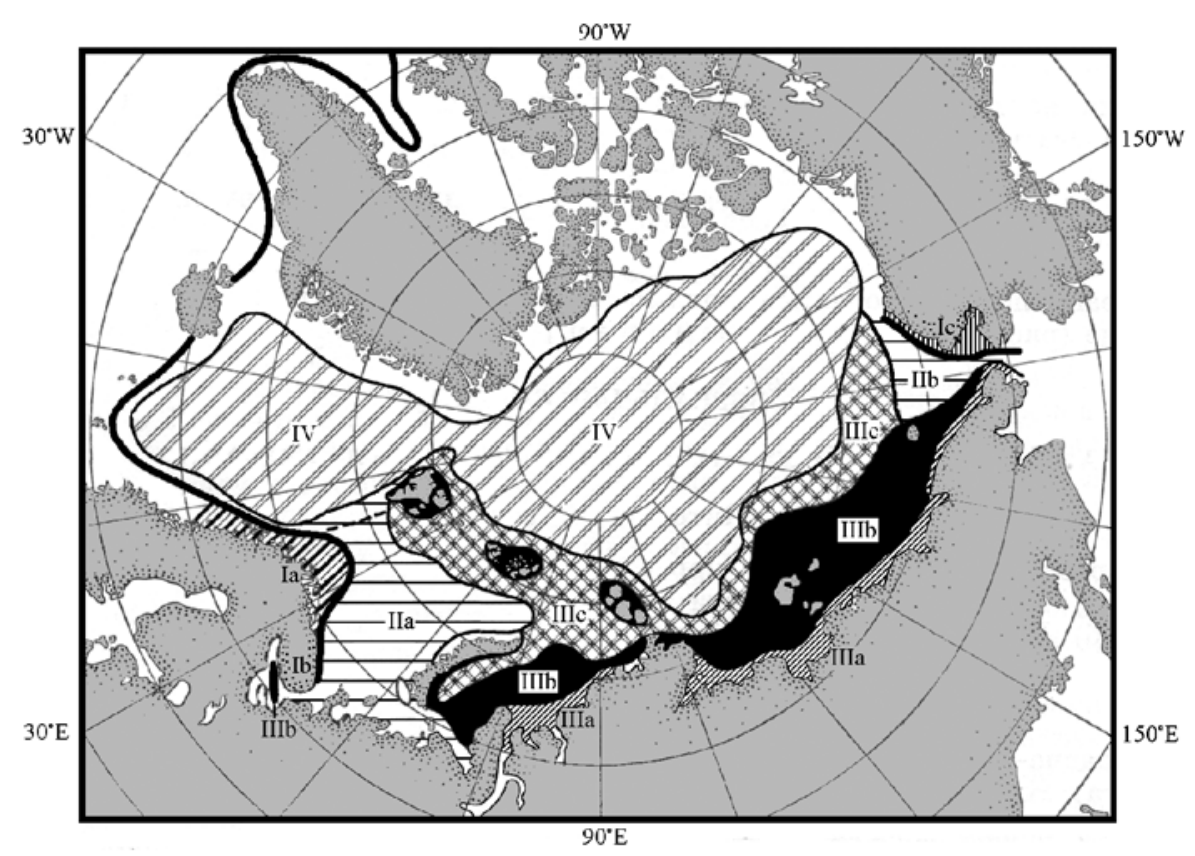

Fig. 11. Biogeographic division of the Arctic Ocean based on the distribution of bivalve mollusks (after Filatova, 1957).

Boreal Region: Ia and I b - North Boreal Atlantic Subregion, Norwegian-Murman-White Sea Province with two districts. Ic - North Boreal Pacific Subregion.

Arctic Region: II — Low-Arctic Sublittoral Subregion, IIa - Barents Sea Province, IIb — Chukchi Sea Province; III High-Arctic Subregion, IIIa - Siberian Upper-Sublittoral Brackish-Water Province, IIIb - Siberian-White Sea Sublittoral Marine Province, IIIc - Eurasian Province of bathyal zone; IV — Polar-Greenland Province of abyssal zone. Рис. 11. Биогеографическое районирование Северного Ледовитого океана на основе распространения двустворчатых моллюсков (по Филатовой, 1957).

Бореальная Область: Іа и $\mathrm{Ib}$ - Северо-Бореальная Атлантическая Подобласть, Норвежско-МурманскоБеломорская Провинция с двумя районами; Ic - Северо-Бореальная Тихоокеанская Подобласть.

Арктичекая Область: II - Нижнеарктичекая Сублиторальная Подобласть, ІІа - Баренцевоморская Провинция, $\mathrm{IIb}$ - Чукотская Провинция; III - Нижнеарктическая Сублиторальная Подобласть, IIІа - Сибирская ВерхнеСублиторальная (прибрежная) Солоноватоводная Провинция, IIIb - Сибирско-Беломорская Сублиторальная Морская Провинция, IIIc - Евразийская Морская Батиальная Провинция; IV — Высокоарктическая Абиссальная Полярно-Гренландская Провинция.

mov, 1989; Petryashov, 2004) (Fig. 12). Mironov and Dilman (2010) used the robust biotic approach to reveal crowding zones in the East Siberian Sea. The species ranges of 43 species of echinoderms from the East Siberian and Laptev Seas were represented as horizontal lines. Detailed data on the distribution of these species were given by Smirnov and Smirnov (1990, 1994, 2006, 2010). On Fig. 13 lines outlining species distribution are with breaks if a species range has a disjunction of more than $10^{\circ}$ along the latitude. Lines end with an asterisk if a species range has a limit in this region. The resulting scheme demonstrates numerous dis- junctions and species range limits in the East Siberian Sea and a small number of range disjunctions and limits in the Laptev Sea (19 and 3 species range limits respectively). Compared to the Laptev Sea, the network of species range limits in the East Siberian Sea appears as a wide crowding zone stretching almost over the whole sea. The width of this zone is almost $1000 \mathrm{~km}$. In Cumacea and Mysida, the relative numbers of species range limits in the East Siberian and Laptev Seas are comparable to echinoderms: 11 East Siberian Sea/4 Laptev Sea species range limits in Cumacea and 8 East Siberian Sea/3 Laptev Sea range limits in Mysida (Table 4). 


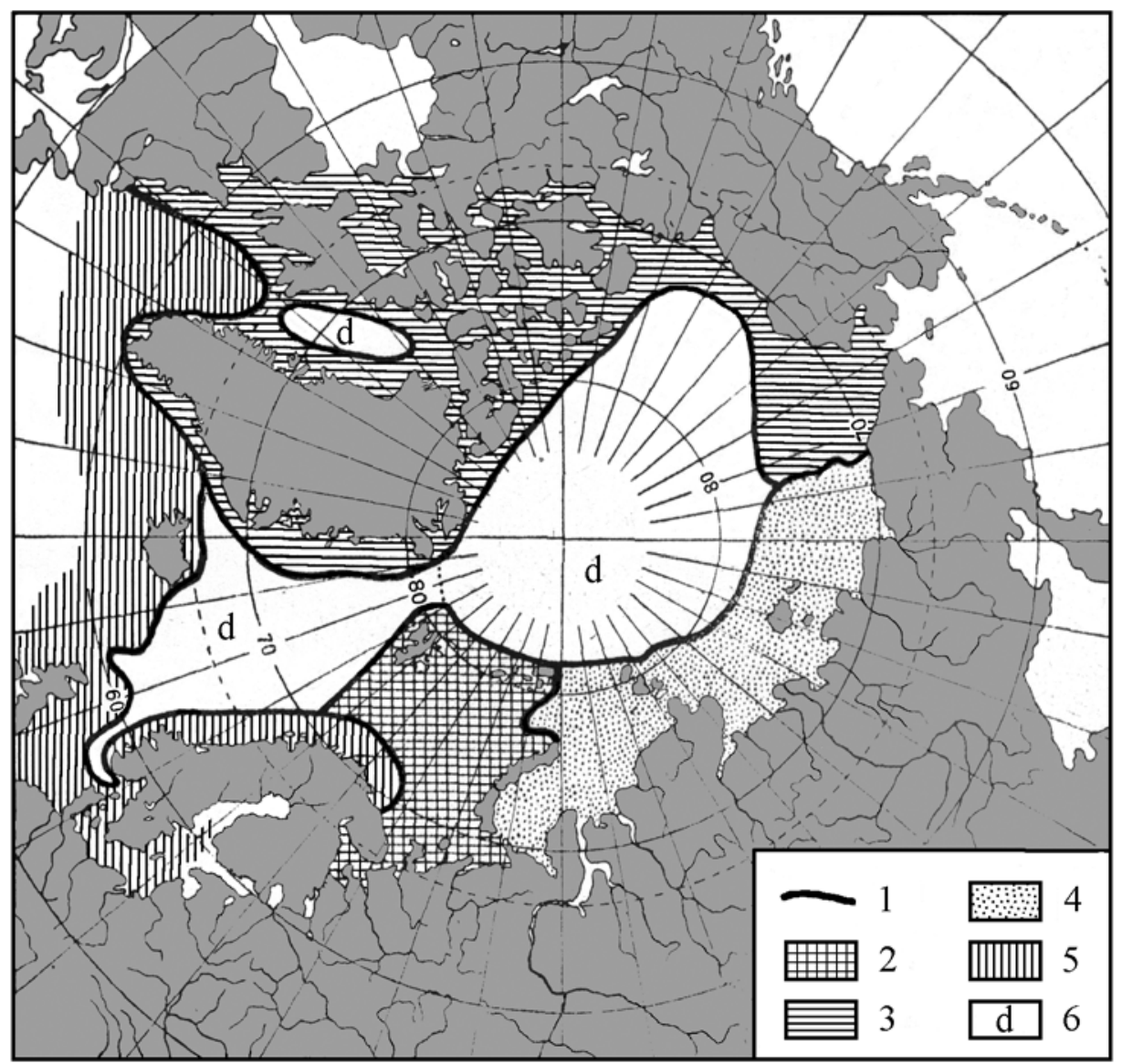

Fig. 12. Biogeographic division of the Arctic Ocean based on the distribution of amphipods (after Gurjanova, 1951).

1 - biogeographic boundaries; 2, 3 and 4 - provinces of the Sublittoral-Upper Bathyal Arctic Region, including White Sea- Spitsbergen Province (2), Chukchi-American Province (3), Siberian Province (4); 5 - Boreal Region; 6 - Deep Sea Arctic Region.

Рис. 12. Биогеографическое районирование Северного Ледовитого океана на основе распространения бокоплавов (по Гурьяновой, 1951).

1 - биогеографические границы; 2, 3, и 4 - провинции Сублиторальной-Верхнебатиальной Арктической Области, включая Беломорско-Шпицбергенскую Провинцию (2), Чукотско-Американскую Провинцию (3) и Сибирскую Провинцию (4); 5 - Бореальная Область; 6 - Глубоководная Арктическая Область.

A wide crowding zone in schemes is replaced by (or shown as) a single line. For example, a crowding zone can be replaced by line connecting points where the number of boreal and arctic species is equal (Shorygin, 1928; Anisimova, 1989, 2000b; Zenzerov et al., 2006). Such a line may occur in a crowding zone but it does not correspond to the notion of a 'biotic boundary'. Jirkov (2013) drew a line along the outer edge of the crowding zone. Similarly,
Sirenko et al. (2009) show a generalized boundary of a species group as a single line. As a result erroneous impression may appear that boundaries of numerous species ranges coincide completely and that the boreal and arctic elements contact each other nearly along a single line. This results in the false impression that in the Barents Sea the boreal fauna is substituted by the arctic fauna along a single line (Fig. 14A). Figure 14B shows more realistic cartographic 
Table 4. Species of Cumacea and Mysida with a range limit on the shelf of the Laptev Sea and the East

Siberian Sea (not known from the Chukchi Sea or from the Laptev - Kara Seas). The table is based on published data of Vassilenko (1990, 2001, 2002, 2004, 2008a, b, 2010), Petryashov (1989, 1990, 2002a,

b, 2004, 2009) and Audzijonytë (2006).

Таблица 4. Список видов Cumacea и Mysida, границы ареалов которых проходят по шельфу Восточно-Сибирского и Лаптевых морей. Таблица составлена на основе данных, опубликованных Василенко (1990, 2001, 2002, 2004, 2008a, b), Петряшева (1989, 1990, 2002a, b, 2004, 2009) и Audzijonytë (2006).

\begin{tabular}{|c|c|c|}
\hline Groups of the shelf species, & Cumacea species & Mysida species \\
\hline $\begin{array}{l}\text { Species with a range limit } \\
\text { within the East Siberian Sea } \\
\left(140^{\circ}-180^{\circ} \mathrm{E}\right)\end{array}$ & $\begin{array}{l}\text { Campylaspis globosa } \\
\text { Diastylis bidentata } \\
\text { D. lepechini } \\
\text { D. oxyrhyncha } \\
\text { D. scorpioides } \\
\text { Eudorella arctica } \\
\text { Lampros quadriplicatus } \\
\text { Leptostylis longimana } \\
\text { Leucon kobjakovae } \\
\text { L. nathorsti } \\
\text { L. pallidus }\end{array}$ & $\begin{array}{l}\text { Birsteiniamysis inermis } \\
\text { Boremysis arctica } \\
\text { Erythrops abyssorum } \\
\text { E. erythrophthalma } \\
\text { Meterythrops robusta } \\
\text { Michtyops theeli (?) } \\
\text { Mysis arcticoglacialis } \\
\text { M. polaris (cryopelagic) }\end{array}$ \\
\hline $\begin{array}{l}\text { Species with a range limit } \\
\text { within the Laptev Sea }\left(100^{\circ}-\right. \\
\left.140^{\circ} \mathrm{E}\right)\end{array}$ & $\begin{array}{l}\text { Campylaspis rubicunda } \\
\text { Eudorella spitzbergensis } \\
\text { Eudorellopsis integra } \\
\text { Paraleptostylis arctica }\end{array}$ & $\begin{array}{l}\text { Boremysis nobilis } \\
\text { Erythrops glaciali } \\
\text { Mysis salemaai }\end{array}$ \\
\hline $\begin{array}{l}\text { Species excluded from } \\
\text { consideration (primarily } \\
\text { bathyal species with rare } \\
\text { records from shelf of the } \\
\text { Laptev and East Siberian seas) }\end{array}$ & $\begin{array}{l}\text { Diastylis echinata } \\
\text { D. polaris } \\
\text { Hemilamprops uniplicatus } \\
\text { Leptostylis gorbunovi } \\
\text { L. macrura } \\
\text { Leucon profundus }\end{array}$ & $\begin{array}{l}\text { Parerythrops } \\
\text { spectabilis }\end{array}$ \\
\hline $\begin{array}{l}\text { Species excluded from } \\
\text { consideration (reported from } \\
\text { the area by Vassilenko in 1990, } \\
\text { but not reported in her later } \\
\text { publications) }\end{array}$ & Eudorella hispida & \\
\hline
\end{tabular}

version of species groups (the types of species ranges). In this version species range boundaries of one type do not coincide completely with each other and widely overlap with species ranges of another type.

\subsection{Deep-sea basins}

Most authors recognize the abyssal zone of the Arctic Ocean as a homogenous biogeographic area with no biogeographic boundaries (Gurjanova, 1951; Filatova, 1957; Zenkevitch, 1963a, b; Briggs, 1974, 1995; Bouchet, Warén, 1979; Andriyashev, Shaposhnikov, 1985; Tsvetkova, 1985; Nesis, 1987; Belyaev, 1989; Vinogradova, 1997; Watling et al., 2013) (Figs 10-12). Wood and Whatley (1994) suggested two abyssal biogeographic regions: the Norwegian and the Arc- tic. Fedyakov and Naumov (1989) drew the region boundary across the Fram Strait (between the Norwegian-Greenland and Central Arctic Basins). Filatova (1962) suggested the boundary along the Lomonosov Ridge dividing the West Polar and the East Polar Abyssal Provinces. According to Jirkov and Leontovich (2012), the boundary between the Deep North Polar Province and the Norwegian Deep Province goes along the boundary between the Greenland Sea and the Norwegian Sea.

The composition of the Arctic abyssal species and genera changes markedly in the Fram Strait area (at transition from the Greenland Sea to the Arctic Basin). Mironov et al. (2013) examine the distribution patterns of 93 Arctic genera, among them 11 are known only in the Norwegian and Greenland Seas and 5 only in 


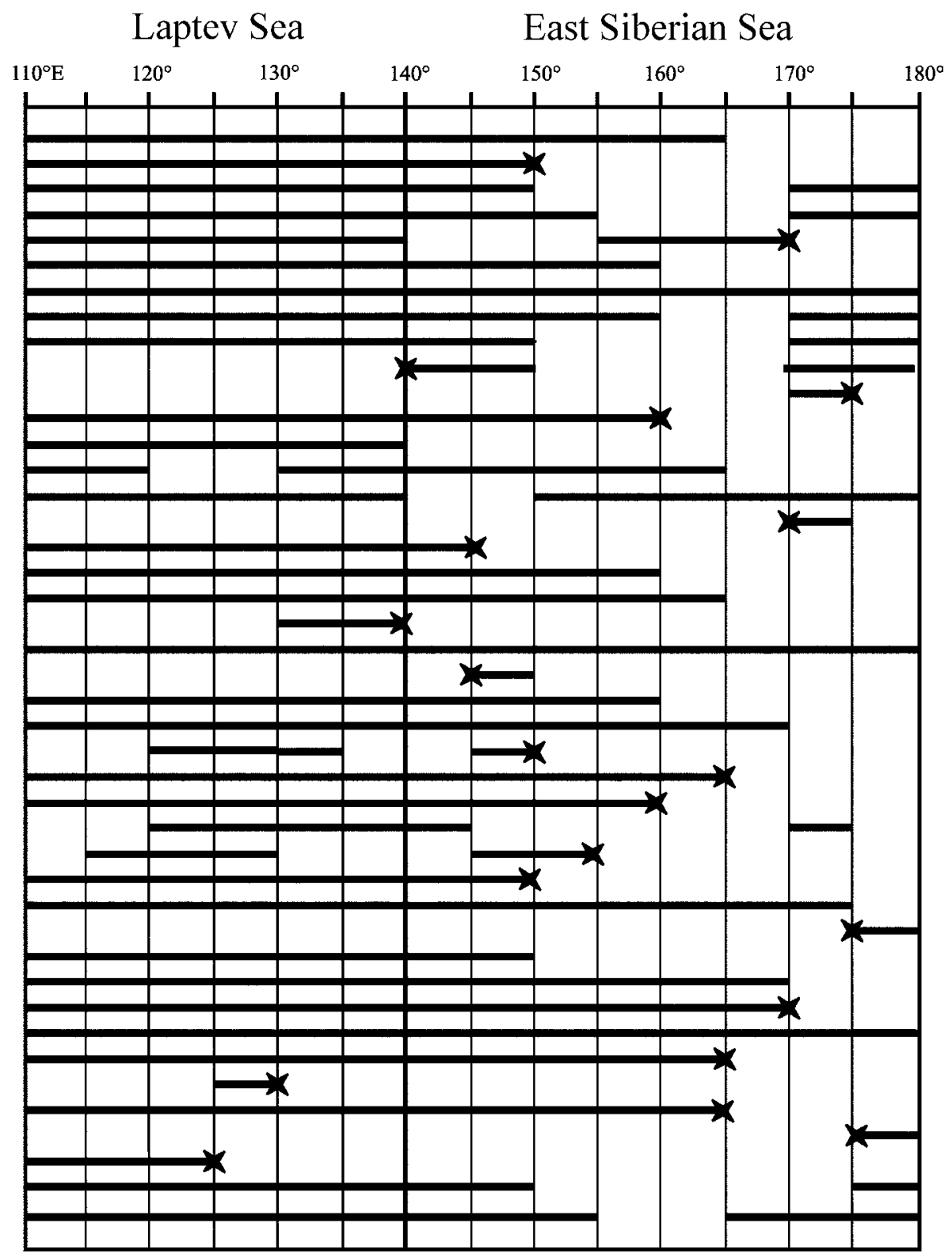

Fig. 13. Distribution of echinoderm species on the Laptev and East Siberian Sea shelves (after Mironov and Dilman, 2010). The horizontal line indicates species presence in a certain longitudinal gradient. The line breaks indicate species range disjunctions (shown only for $10^{\circ}$ distance and more). The species range limits are indicated by four-arm asterisks.

Рис. 13. Распространение видов иглокожих на шельфе Лаптевых и Восточно-Сибирского морей. Горизонтальная линия означает наличие вида в соответствующем диапазоне долгот. Разрывы линий соответствуют разрывам ареалов. Показаны лишь крупные разрывы ареалов протяженностью в $10^{\circ}$ и более. Четырехлучевой звездочкой обозначены границы видовых ареалов (по Миронову и Дильман, 2010). 


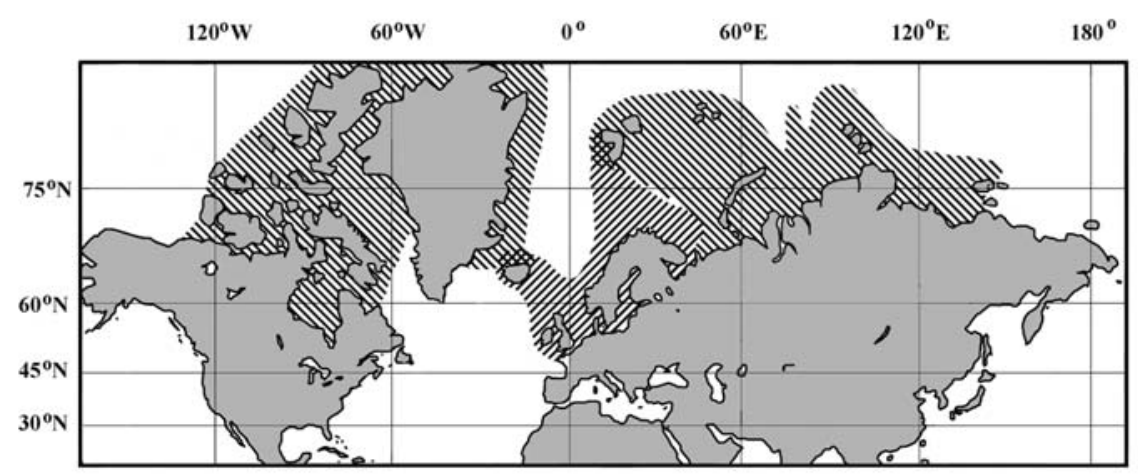

A

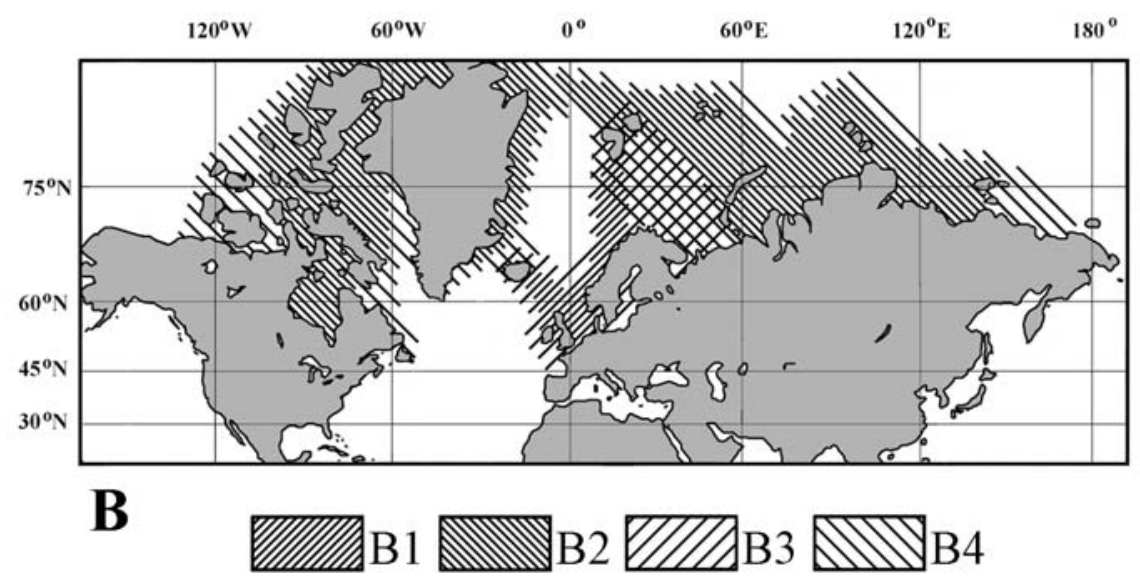

Fig. 14. Two ways (A and B) of representing, cartographically, two geographic elements of the Arctic biota: boreal Eastern Atlantic element (A1 and B1) and Arctic-Eurasian element (A2 and B2).

A - based on assumption that the range limits of species of the same geographical element completely coincide; geographical elements adjoin to each other in the Barents Sea (after Sirenko et al., 2009).

$\mathrm{B}$ - based on assumption that the range limits of species of the same geographical element do not coincide: they are dispersed within the zones B3 (Eastern Atlantic species) and B4 (Arctic-Eurasian species). Geographical elements widely overlap in the Barents Sea.

Рис. 14. Два способа (А и В) картографической репрезентации двух географических элементов арктической биоты: бореального восточного атлантического (А1 и В1) и арктическо-евразийского (А2 и $\mathrm{B} 2$ ).

А - принято допущение, что границы ареалов видов, относящихся к одному и тому же географическому элементу, полностью совпадают; географические элементы соприкасаются друг с другом в Баренцевом море (по Sirenko et al., 2009).

В - принято допущение, что границы ареалов видов, относящихся к одному и тому же географическому элементу, не совпадают: они рассеяны в зонах В3 (восточно- атлантические виды) и В4 (арктическо-евразийские виды). Географические элементы широко перекрываются в Баренцевом море.

the Arctic Basin. However data on species range limits in the deep-sea is incomplete. Approximately half of deep-sea taxa (occurring deeper $500 \mathrm{~m}$ ) are known only from one or two localities (Bluhm et al., 2011). Additional biotic stud- ies are required to clarify the crowding zone in the Fram Strait.

The Deep-Sea Subregion of the North Polar Region is considered here with a conventional upper boundary at $1200 \mathrm{~m}$ and it is not divided 
into provinces. The Deep-Sea Subregion is separated from the northern Atlantic and the northern Pacific deep-sea regions by pronounced crowding zones along the northern slope of the Greenland-Iceland-Faeroe Ridge and the continental slope of the Chukchi Sea. Deep-sea boundaries in these areas have been shown for many taxa (Gurjanova, 1951; Filatova, 1957; Zenkevitch, 1963a, b; Briggs, 1974, 1995; Bouchet, Warén, 1979; Andriyashev, Shaposhnikov, 1985; Tsvetkova, 1985; Nesis, 1987; Svavarsson et al., 1993; Emson et al., 1994; Negoescu, Svavarsson, 1997; Vinogradova, 1997; Weisshappel, 2000; Clarke, 2003; Narayanaswamy et al., 2005; Figs. 10-12).

There are two opinions on the subordination of the shallow-water and deep-sea biogeographic regions of the Arctic Ocean. In one, the Arctic deep-sea and shallow-water subdivisions are combined into the Arctic division of a higher rank (Filatova, 1957, 1962; Zenkevitch, 1963a, b; Tsvetkova, 1985; Figs 10, 11). In the other, the Arctic deep-sea subdivisions are combined with the Atlantic deep-sea subdivisions. In the latter approach, the biogeographic schemes of the World Ocean abyssal and shelf are not hierarchically associated (Ortmann, 1896; Menzies et al., 1973; Belyaev, 1989; Vinogradova, 1997; Jirkov, 2010; Watling et al., 2013). However, Menzies et al. (1973) combined into the Arctic Deep-Water Region the deep-sea basins and slope areas with the upper border at $425 \mathrm{~m}$.

Numerous species are common to both shallow-water and deep-sea regions; also there are numerous deep-sea species with wide bathymetric ranges. Bluhm et al. (2011) demonstrated that the shelf and the deep-sea $(>500 \mathrm{~m})$ macro- and megabenthic faunas share $\sim 60 \%$ of species. There are numerous examples of evolutionary emergence or submergence of the Arctic taxa (Mironov et al., 2013). The distribution patterns of taxa and their biogeographic history suggest that the Deep-Sea Subregion should be united with the Shelf-Upper Slope Subregions of the North Polar Region rather than with deepsea regions of the Atlantic or the Pacific.

Replacement of shallow-water fauna by deep-sea fauna occurs in different ways in seas of the Arctic and the northern Atlantic (Fig. 15). The boreal shallow-water and the boreal deepsea faunas are contiguous in the northeast Atlantic, whereas the boreal shallow-water fauna is replaced by the arctic deep-sea fauna in the eastern Norwegian Sea. The transitional (arcticboreal) shallow-water fauna is replaced by the boreal deep-sea fauna in the Labrador Sea, whereas the transitional shallow-water fauna and the deep-sea arctic fauna are contiguous in the Barents and Chukchi Seas. In the Kara, Laptev, East-Siberian and Beaufort Seas, the arctic shallow-water fauna is contiguous with the arctic deep-sea fauna.

\section{Community (biocenotic) region- alization}

Schemes of biocenotic subdivisions of the Arctic seas were given in numerous publications (Filatova, Zenkevitch, 1957; Zenkevitch, 1963a, b; Kuznetsov, 1976; Antipova, Semenov, 1989; Kiyko, Pogrebov, 1998; Sirenko, 1998; Anisimova, 2000b, 2003; Deubel et al., 2003; Frolova, 2003; Lyubin, 2003; Kulakov et al., 2004; Steffens et al., 2006; Zenzerov et al., 2006; Denisenko, 2008; Lyubina, Sayapin, 2008 etc.). The Barents Sea has been subdivided based mainly on the biocenotic approach by Anisimova (2000b) and Zenzerov et al. (2006). The similarity of faunas at individual stations was estimated using the Jaccard's index ignoring the assumption of continuity of species ranges; species were regarded as equally important (Anisimova, 2000b). Stations were split into 26 uniform faunistic groups and arranged into 65 primary areas. Single stations represented about half of the primary areas. To reveal the biogeographic regions these 65 primary areas were clustered using the Czekanowski-Sørensen index. Similarity was estimated based not on the species composition but on the "biogeographic structure of fauna": the percentage of species from different geographic elements (arctic and boreal). This resulted in nine biogeographic areas, four of them being transitional between the boreal and arctic faunas (Fig. 16).

In most publications based on the biocenotic approach, the importance of species differs in respect to abundance, biomass etc. Lyubina and Sayapin (2008) compared stations by species composition of the gammarid fauna, population density and the biomass dominance. Similarity was estimated by cluster analysis using the Czekanowski-Sørensen index. This resulted in seven subdivisions in the Kara Sea. According to 

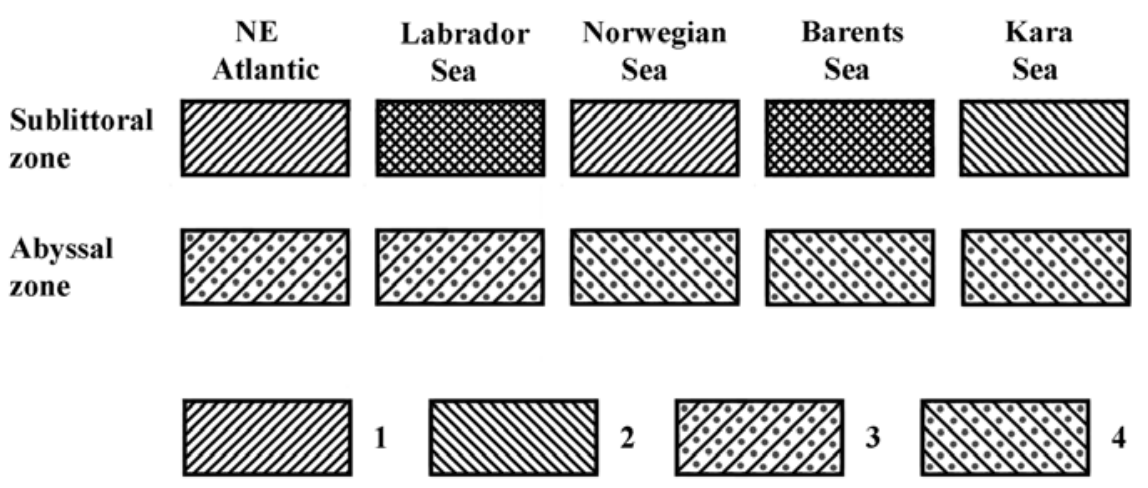

Fig. 15. Combinations of latitudinal zonal characteristics of shallow-water and deep-water faunas in the seas of the North Atlantic and Arctic Ocean.

1 - boreal shallow-water fauna (North-Eastern or North-Western Atlantic Regions); 2 - arctic shallow-water fauna (Shelf-Upper Slope Subregion of the North Polar Region). 3 - boreal deep-sea fauna (North Atlantic Deep Sea Region); 4 - arctic deep-sea fauna (Deep Sea Subregion of the North Polar Region).

Рис. 15. Комбинации широтных зональных характеристик мелководной и глубоководной фаун в морях Северной Атлантики и Северного Ледовитого океана.

1 - бореальная мелководная фауна (Северо-Восточная или Северо-Западная Атлантические Области); 2 арктическая мелководная фауна (Шельфовая-Верхнебатиальная Подобласть Северной Полярной Области); 3 бореальная глубоководная фауна (Североатлантичекая Глубоководная Область); 4 - арктическая глубоководная фауна (Глубоководная Подобласть Северной Полярной Области).

results of cluster analysis, Kulakov et al. (2004) mapped 15 benthic communities in the Barents Sea and 20 benthic communities in the Kara Sea. These communities were characterized by dominance of species and they were combined into five trophic zones.

\section{Landscape (bionomic) regiona- lization}

Gukov (1999) used the classic landscape approach, where large-scale subdivisions are based on non-biological criteria (Table 2). He revealed regularly repeating types of landscape complexes on the Laptev Sea shelf: 31 facies, 25 areas and four landscapes. Only the facies were characterised by specific communities. The Laptev Sea was subdivided by Gukov into seven regions distinguished by sets of typical (repeating) landscape complexes. Later Gukov (personal communication) suggested a new version of the scheme for the Laptev Sea (Fig. 17) with six regions and the scheme of regionalization of the East Siberian Sea with five regions.

Petrov (2009) discussed the hierarchy of landscape- and biome-based regionalization, ranging from the global to local scale, using the
Barents Sea as an example. The Sea was subdivided into seven landscape ("bionomic") regions, resembling more the tectonic and geomorphological subdivisions than the biocenotic and biotic.

The landscape approach to regionalization was used in studies of the Eastern Canadian Arctic and northwest Atlantic, with biogeographic regions being related mainly to patterns of water masses. According to Dunbar (1972), the Northwest Atlantic Marine Region extends from the Cape Hatteras northward along the eastern coast of the United States to Lancaster Sound at the northern end of the Baffin Island then westward to the Bering Strait in Alaska. Later Dunbar (1988) proposed three secondorder subdivisions: the Polar, Subpolar and Eastern Temperate Provinces. These provinces were based on water mass features, including temperature, salinity, origin of water masses, current and tidal patterns, sea-ice cover, vertical stability of the water column and biological indicators (Cook, Auster, 2007). Mondor et al. (1995) further subdivided these provinces into ten third-order marine biogeographic regions based on the identification of marginal seas. These included four Polar subdivisions (Vis- 

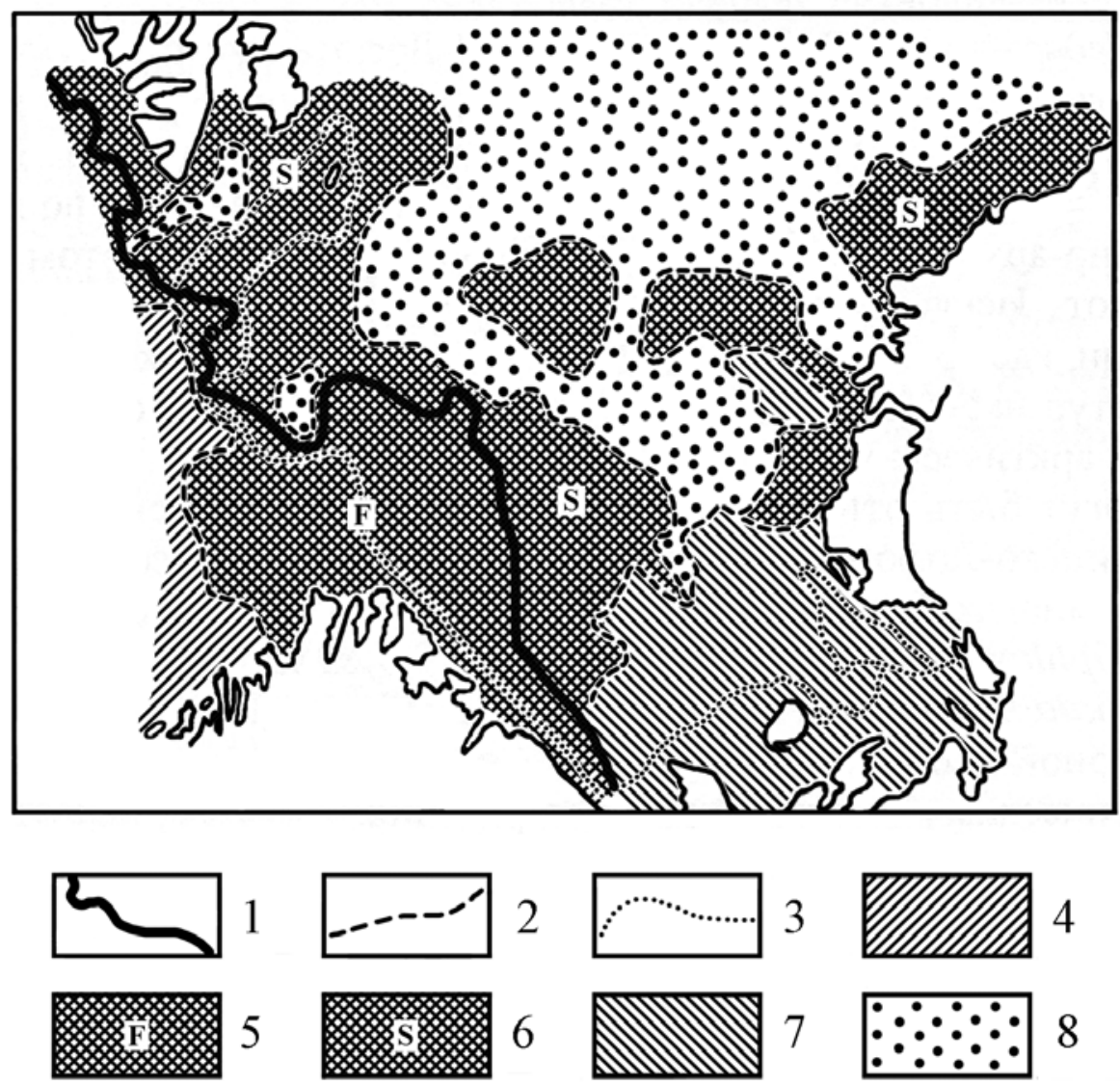

Fig. 16. Biogeographic division of the Barents Sea based mainly on the biocenotic approach (after Anisimova, 2000b; modified).

1 - boundary between Atlantic Boreal Region and Arctic Region (or between Norwegian and West Arctic Provinces), this line connects points where the number of boreal and arctic species is equal; 2 - boundary between districts; $3-$ boundary between areas; 4 - Lofoten District; 5 - Finmark Subarctic Transitional District (disrupted, with two areas); 6 - Spitsbergen - Novaya Zemlya Subarctic Transitional District (disrupted, with two areas); 7 - South-Eastern Barents District (disrupted, with three areas); 8 - Central Barents Deep-Sea District.

Рис. 16. Биогеографическое районирование Баренцева моря основанное преимущественно на биоценотическом подходе (по Анисимовой, 2000b; модифицировано).

1 - граница между Атлантической Бореальной Областью и Арктической Областью (или между Норвежской Высокобореальной и Западно-Арктической Провинциями); эта линия соединяет точки, в которых число бореальных видов равно числу арктических видов; 2 - граница между округами; 3 - граница между районами; 4 - Лофотенский Округ; 5 - Финмаркенский Субарктический Переходный Округ (разорванный, с двумя районами); 6 - Шпицбергенско-Новоземельный Субарктический Переходный Округ (разорванный, с двумя районами); 7 - Юго-Восточный Баренцевоморский Округ (разорванный, с тремя районами); 8 - ЦентральноБаренцевоморский Округ.

count Melville Sound, Lancaster Sound, Hudson Strait and Hudson James Bay), three Subpolar (North Slope/Beaufort Sea, Labrador Shelf and Gulf of St. Lawrence) and three Eastern
Temperate subdivisions (Grand Banks/Scotian Shelf, Acadian and Virginian). Cook and Auster (2007) recognized five third-order subdivisions of the Eastern Temperate Province. 


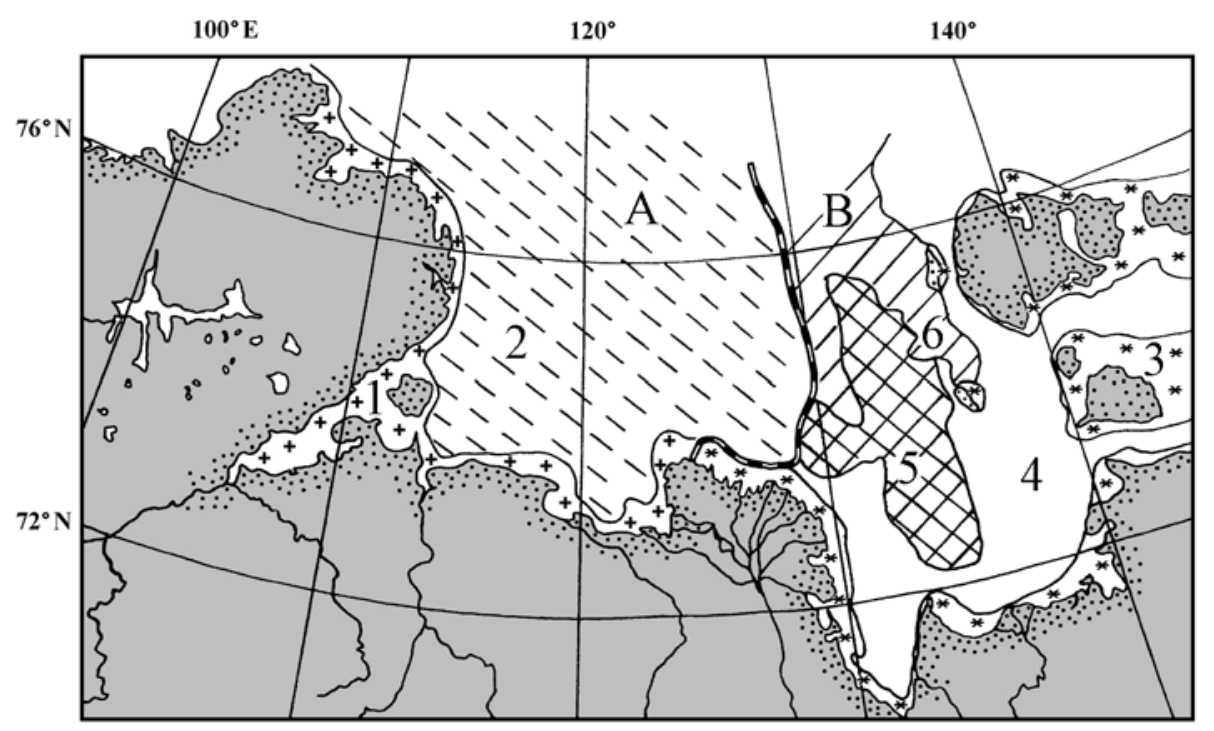

Fig. 17. Biogeographic division of the Laptev Sea by the landscape approach (after Gukov, pers. communication).

A - West-Laptev Province: 1 - Offshore West-Laptev Area; 2 - West-Laptev Accumulation Area. B — East-Laptev Brackish-water Province: 3 - Offshore East Laptev Area; 4 - East-Laptev Accumulation Area; 5 - Shallow-water area; 6 - Area of Underwater Valleys. Dashed line shows the border between provinces. The figure is published by permission of A.Yu. Gukov.

Рис. 17. Биогеографическое районирование моря Лаптевых с помощью ландшафтного подхода. По А.Ю. Гукову, неопубликовано.

A - Западно-Лаптевская Провинция: 1 - Прибрежный Западно-Лаптевский Район; 2 - Западно-Лаптевский Аккумулятивный Район. В - Восточно-Лаптевская Солоноватоводная Провинция: 3 - Прибрежный ВосточноЛаптевский Район; 4 - Восточно-Лаптевский Аккумулятивный район; 5 - Мелководный Район; 6 - Район Подводных Долин. Черно-белой линией показана граница между провинциями. Рисунок публикуется с разрешения А.Ю. Гукова.

\section{Regionalization based on the mixed approach}

\subsection{Shelves}

Most biogeographic schemes were constructed based on a mixture of elements of the biotic, biocenotic and landscape approaches. Dunbar (1979) stated, "the biogeographic method does not exist, or there are as many methods as biogeographers". It's more accurate to say that there are as many combinations of the biotic, biocenotic and landscape approaches to regionalization as biogeographers. Data on species, community and biotope (habitat) distribution patterns are mixed to draw a single line of a species range, to reveal a biogeographic unit and to construct a biogeographic scheme of the Arctic Ocean. Boundaries based on species distribution are combined in a scheme with boundaries based on community and landscape criteria.

One simple example of the mixed approach (biotic + biocenotic) is a map of biotic units for different vertical zones (Fig. 11). Such a map usually shows disjunctive units when one and the same province is represented by several parts separated from each other by another province (Filatova, 1957; Jirkov, Leontovich, 2012) (Fig. 11). This contradicts the assumption of continuity of a species range i.e. the continuity of a biotic unit (Fig. 4 and 5). Another simple case of mixed biotic/biocenotic approach is recognition of a crowding zone as independent biogeographic unit of transitional nature. For example, the Barents Sea shelf or its section are often recognized as a separate biogeographical province (Schmidt, 1904; Gurjanova, 1951; Filatova, 1957; Zenkevitch, 1963a, b; Nesis, 
1982, 1987; Zinova, 1985; Fedyakov, Naumov, 1989; Golikov et al., 1990; Petryashov, 2009; Jirkov, Leontovich, 2012), whereas a pure biotic approach reveals in this area only a crowding zone (wide biogeographical boundary) without a status of separate unit.

Naumov (2006) divided the White Sea into 10 hydrological areas. The bivalve faunas of these areas were compared using paired Bravais-Pearson's correlation coefficients. Areas were grouped in case the correlation between them exceeded 0.5 . The significance of this value at the given number of species was $95 \%$. As a result, six biogeographic regions were revealed by the mixed landscape/biocenotic approach (Fig. 18).

Lubinsky (1980) divided the Eastern and Central Canadian Arctic into 12 biogeographic regions (Fig. 19). This scheme was based on maps of the distribution of 64 species of bivalves and addressed the problem of the division of arctic and subarctic waters. These maps can be used to evaluate whether the biogeographic boundaries suggested by Lubinsky are the crowding zones of species range borders. Based on the assumption of species range continuity, I calculated numbers of species range borders near the high biogeographic rank boundary, between the Arctic and Subarctic Faunistic Zones. The boundary between regions IId and VIa (the western part of the boundary between the Arctic and Subarctic Zones) coincides with species range borders of only two species, $C y$ clocardia borealis and Yoldiella lenticula. The nearest borders of other species (Astarte elliptica, Macoma loveni, Thracia myopsis and Yoldia myalis) are rather distant from each other. The border of one species, Turtonia minuta, goes very close to the boundary between the IIc and VIa regions (the eastern part of the boundary between zones). The number of species range borders in the vicinity of the low-rank biogeographic boundaries of Lubinsky also is low. For example, the boundary between subprovinces $\mathrm{IIa}$ and IIb is the limit of distribution only for Crenella faba. Therefore, the high number of biogeographic units in the Canadian Arctic is not supported by pure biotic approach. These units are probably a result of the mixing of the biotic, biocenotic and bionomic approaches.

The definitions of "arctic species" and "boreal species" often include ecological or historical meaning, such as occurrence of a species at certain temperatures, or species origin at polar or temperate latitudes. The species and community criteria are mixed when the "boreal" and "arctic" species in such sense are used for the biogeographic regionalization. Species are also attributed to "arctic" if they occur only in the "Arctic Region", and "boreal" if they occur only in the "Boreal Region". In this case, the distinguishing of "arctic" and "boreal" species largely depends on the location of the biogeographic boundary between the Arctic and Boreal Regions. Semenov (1986) described this vicious circle in the method revealing biogeographic boundaries: first, the arctic and boreal types of distribution are defined based on the suggested border between the Arctic and Boreal biogeographic regions, then these distribution types are used for clarifying the biogeographic boundary between the Arctic and Boreal regions. Cluster analysis ignores the assumption of continuity of species ranges. Therefore cluster analysis leads to the mixing of biotic and biocenotic approaches. Data on species distribution are often not sufficient to reveal boundaries of species ranges and biotic regions. In such cases Petrov (2009) suggests substituting the biotic criteria of regionalization by the biocenotic and landscape criteria. The landscape approach was initially treated as a combinatorial one. It was claimed that the landscape approach gives a "polycentric vision" of an ecosystem and thus has advantages over biotic and biocenotic approaches that provide only limited "biocentric" view (Arzamascev, Preobrazhensky, 1990; Petrov, 2008). Similarly the mixed approach was usually treated as the most effective to reveal the boundaries of ecoregions and large ecosystems. Thus Spalding et al. (2007) defined the marine ecoregions as "distinct areas of relatively homogeneous species composition, which is likely to be determined by the predominance of a small number of ecosystems and/or a distinct suite of oceanographic or topographic features". These authors distinguished 19 shelf ecoregions in the Arctic Realm.

\subsection{Estuaries}

The Arctic Ocean is characterized by strong freshwater outflow. The annual freshwater discharge from all major Arctic rivers is approximately $3300 \mathrm{~km}^{3}$, equivalent to $10 \%$ of global 


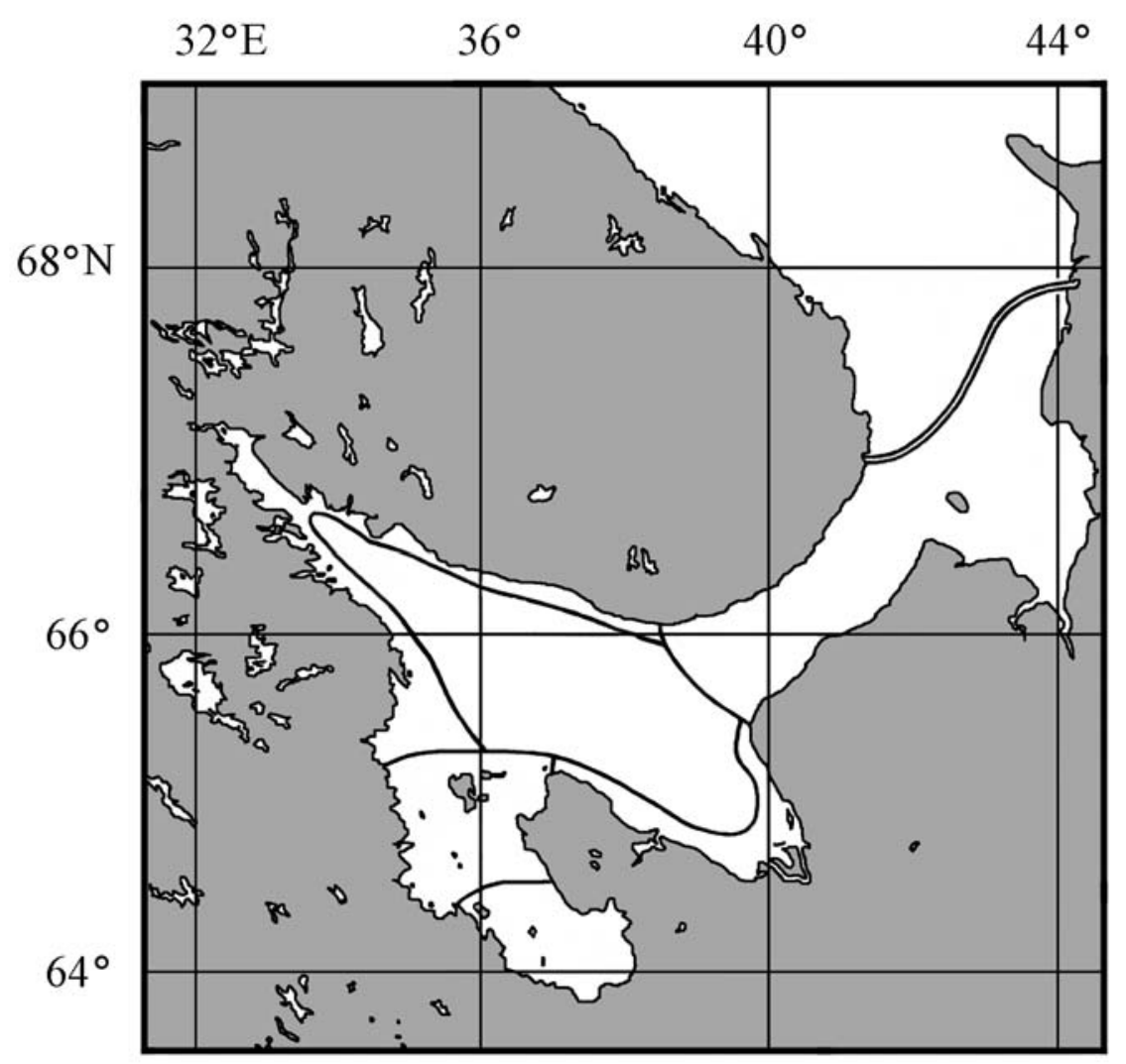

Fig. 18. Biogeographic divisions of the White Sea based on species prevailing in the bivalve mollusc fauna (see explanations in text). Double line designates the coincidence of oceanographic and faunistic boundaries of the White Sea. After Naumov, 2006.

Figure 18. Биогеографическое районирование Белого моря, основанное на доминировании видов в фауне двустворчатых моллюсков (см. пояснения в тексте). Двойной линией обозначено совпадение «океанографической и фаунистической границ Белого моря». По Наумову, 2006.

river run-off. The freshwater flow is especially high in the Kara Sea. The $\mathrm{Ob}$ and Yenisei, two of the largest rivers in the basin, discharge about $30 \%$ of the total annual river run-off into the Arctic Ocean (Fütterer, Galimov, 2003; Stein, 2000).

Gorbunov (1941) pointed out that the Arctic brackish-water fauna differs from marine one and suggested the division of the biogeographic Arctic Subregion into two parts: "the high Arctic area of continental water discharge and the high Arctic of the open sea". Following Gorbunov, Zenkevitch $(1947,1963 \mathrm{a}, \mathrm{b})$ recognized the Brackish-Water Province forming a continuous belt along the Eurasian coast from Yamal to the Bering Strait and also along the American coast (Fig. 10). In the scheme of Filatova (1957, 1962), the Brackish-Water Province has a wide gap at the Taimyr Peninsula area (Fig. 11). The Estuarine Arctic Interzonal Province of Golikov et al. (1990) included 11 areas: the southern Kara Sea, the White Sea, Gulf of Finland, Gulf of Bothnia and southern parts of the Laptev and East Siberian Seas, the Gulf of Anadyr in the Bering Sea, the Amur and Mackenzie estuaries, the Gulf of Saint Lawrence on the eastern coast of Canada and the James Bay with an outpost into the south-east Hudson Bay. Gukov (pers. com.) separated the East Laptev and New Siberian Brackish-Water Provinces (Fig. 17). Lubinsky (1980) identified the Brackish Subprovince of the James Bay. Polar water of James Bay 


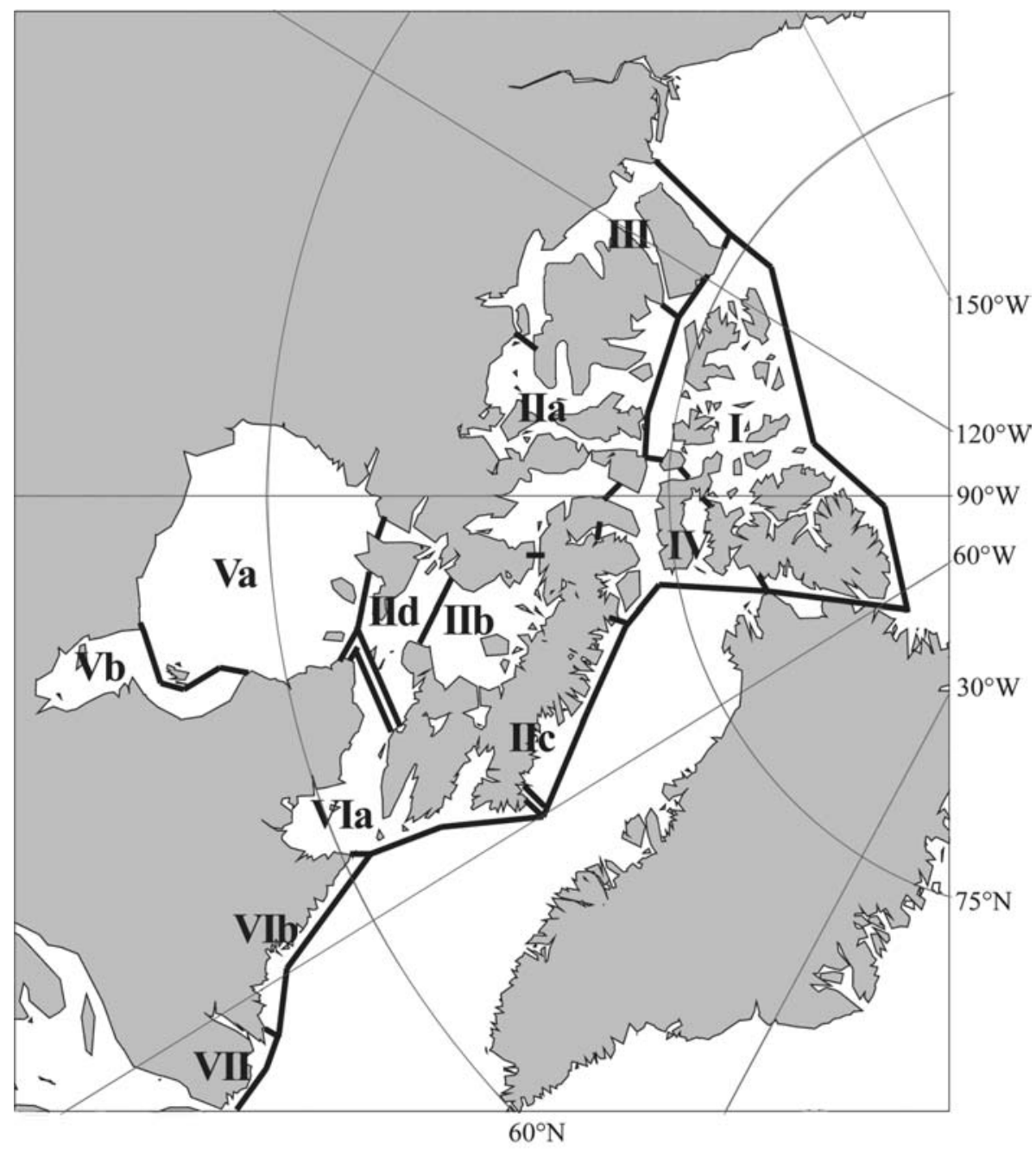

Fig. 19. Biogeographic division of the Canadian Arctic based on the distribution of bivalves (after Lubinsky, 1980).

Faunistic zones and subzones: I-V — Arctic Zone: I-IV — High-Arctic Subzone, V — Low-Arctic Subzone; VI-VII — Subarctic Zone.

Provinces and subprovinces: I - Endemic Province of the Northern Canadian Archipelago, IIa, b - Central ShallowWater Province, IIb - Subprovince of Foxe Basin, IIc - Province of Baffin Island Shelf, IId - Southern Deep-Water Province, III - Province of South-Western Canadian Archipelago, IV - Province of South-eastern Canadian Archipelago, Va, b - Province of Hudson Bay, Vb - Subprovince of James Bay, VIa, b - Northern Subarctic Province, $\mathrm{VIb}$ - Subprovince of Northern Labrador, VII - Province of Southern Labrador.

Рис. 19. Биогеографическое районирование Канадского сектора Арктики, основанное на распространении двустворчатых моллюсков (по Lubinsky, 1980).

Фаунистические зоны и подзоны: I-V - Арктическая зона: I-IV — Высоко-Арктическая Подзона, V — НизкоАрктическая Подзона; VI-VII - Субарктическая Зона.

Провинции и субпровинции: I - Эндемичная Провинция Северного Канадского Архипелага; IIa, b - Центральная Мелководная Провинция; IIb - Субровинция Бассейна Фокси; IIc - Провинция Шельфа Острова Баффин; IId - Южная Глубоководная Провинция; III - Провинция Юго-Западного Канадского Архипелага; IV - Провинция Юго-Восточного Канадского Архипелага; Va, b - Провинция Гудзонова Залива; Vb Субпровинция Залива Джеймс; VIa, b - Северная Субарктическая Провинция; VIb - Субпровинция Северного Лабрадора; VII - Субпровинция Южного Лабрадора. 


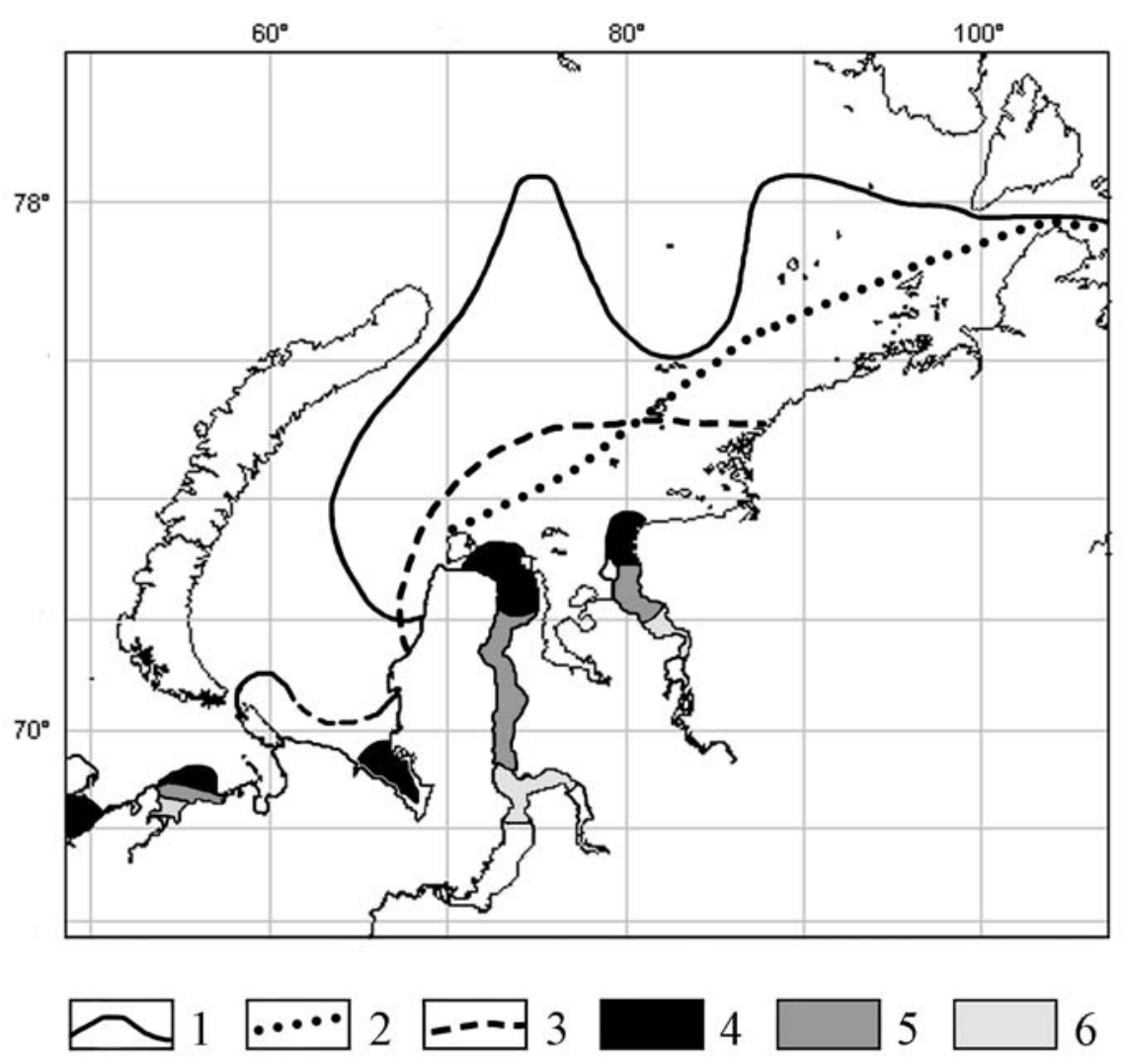

Fig. 20. Boundaries of brackish-water fauna according to various authors in the Kara Sea.

1 - boundary of distribution of brackish-water zooplankton, based mostly on the distribution of Limnocalanus macrurus (= L. grimaldii) and Drepanopus bungei (after Pavshtiks, 1985); 2 - northern boundary of the Shallow Brackish-Water Province (after Zenkevitch, 1963a); 3 - northern boundary of the Estuary Arctic Province (after Golikov, Scarlato, 1989); 4-6 - scheme of faunistic regionalization of inlets and bays of the Kara Sea and the eastern Barents Sea: 4 - marine euryhaline fauna, 5 - brackish-water-marine euryhaline fauna, 6 - brackish-water fauna (after Anisimova, 2000a).

Рис. 20. Границы солоноватоводной фауны, проводимые разными авторами в Карском море.

1 - граница распространения солоноватоводной фауны зоопланктона, проведенная в основном по распространению Limnocalanus macrurus (= L. grimaldii) и Drepanopus bungei. По Pavshtiks, 1985. 2 - северная граница Мелководной Солоноватоводной Провинции. По Зенкевичу, 1963a. 3 - северная граница Эстуарной Арктической Провинции. По Голиков, Скарлато, 1989. 4-6 - схема фаунистического районирования губ и заливов Карского моря и восточной части Баренцева моря: 4 - морская эвригалинная фауна, 5 - солоноватоводноморская эвригалинная фауна, 6 - солоноватоводная фауна. По Анисимовой, 2000а.

is mixed with water from land drainage, "seasonally less saline and warmer than in any other part of the Arctic" (Lubinsky, 1980: 61). In the scheme of Petryashov et al. (2010) the Siberian Brackish-Water Province is divided within the East Siberian Sea into four subdivisions: Polyeuhaline, Polyhaline, Refugium in the Chaun Bay and Refugium in the Estuary of the Kolyma
River. Following Khlebovich (1986), Anisimova (2000a) assigned the Gulf of Ob, the Pechora Bay and the Yenisei Bay not to the Arctic Region, but to the Holarctic Brackish-Water Region of the mainland (Fig. 20).

The estuarine biogeographical units are based on the mixed approach. Golikov and Scarlato (1989) emphasized the landscape criteria and 
suggested that the Estuarine Arctic Province does not descend to depths greater than $10 \mathrm{~m}$, with summer temperatures $4-6^{\circ} \mathrm{C}$ and salinities from 3 to $16 \%$. Estuarine provinces clearly differ from adjacent freshwater and marine areas also in the structure of benthic communities. The freshwater communities are succeeded down-estuary by "oligo-mixed" communities with a strong dominance of brackish water species. These brackish water communities in turn are succeeded by "poly-mixed" communities with mostly marine species prevailing towards the estuary mouth (Filatova, Zenkevitch, 1957; Gukov, 1999, 2001; Anisimova, 2000a; Fetzer et al., 2002; Deubel et al, 2003; Galkin et al., 2010) (Figs 6, 20).

It is likely that there are no species endemic to the estuarine zone. Some species are especially characteristic of estuaries: the planktonic crustaceans Limnocalanus macrurus (= L. grimaldii) and Drepanopus bungei, the polychaetes Ampharete vegae, Marenzelleria arctia, the amphipods Monoporea affinis and Onisimus botkini, the isopod Saduria entomon and others (Denisenko et al., 2003; Deubel et al, 2003; Gagaev et al., 2006; Frolova, 2009; Lyubina, Sayapin, 2008; Galkin et al., 2010). However these species also were recorded at a substantial distance from estuaries.

The transition from the sea to fresh water in estuaries is marked by a drastic reduction in the number of species. Filatova and Zenkevitch (1957) compared two adjacent communities in the Yenisei Bay. At the transition from the marine poly-mixed community, dominated by the bivalve Portlandia arcticum and the amphipods Acanthostepheia malmgreni, and Aglaophamus malmgreni to the brackish-water oligo-mixed community, dominated by the bivalves Portlandia aestuaroum and Cyrtodaria kurriana and the isopod Saduria entomon, the number of species decreased from 200 to 40 . Considering only the amphipod fauna, in the estuary communities of the Kara Sea (the Yenisei Bay and the Gulf of $\mathrm{Ob}$, depths from 4.4 to $29 \mathrm{~m}$, salinity from 0.4 to $20.9 \%$ ) four species occur: Monoporeia gurjanovae (the dominant species), Monoculoides minutus, Oediceros minor and Onisimus birulai), whereas the neighbouring more northern community is dominated by Byblis gaimardi and Protomedea fasciata (depths 18-45 m, salinity 27\%o) and there are 55 species (Lyubina, Sayapin, 2008). The number of polychaete species in Yenisei Bay decreases from 50 to 4 from north to south (Frolova, 2009).

Remane $(1934,1940)$ found that in the Baltic Sea most freshwater species do not occur at salinities $>5-8 \%$, whereas marine species usually do not live at salinities below this value. Khlebovich $(1965,1974,1986,1989)$ was the first to suggest the term "critical salinity" and showed that this narrow salinity range marks the faunal change when seawater is mixed with fresh water. It is a divide for many physiological processes, including cellular and biochemical reactions. The critical salinity barrier of Khlebovich supports recognition of the "holohaline" zone inhabited by brackish-water communities (Kinne, 1971). According to Anisimova (2000a), the zone of brackish-water communities in the Gulf of $\mathrm{Ob}$ approximately coincides with the salinity of 5-8\% (Fig. 10). However, Kozlovskiy (2012) reported that the summer boundary between the freshwater and brackish-water communities was observed in the Gulf of Ob $250 \mathrm{~km}$ south from the $1 \%$ isohaline. Kozlovskiy (2012) suggested that this boundary was determined by water with a higher salinity periodically penetrating the southern Gulf of $\mathrm{Ob}$.

Estuaries of Arctic rivers dramatically differ from other areas of the Arctic Ocean in the environment conditions and the structure of benthic communities. Therefore Arctic estuaries can be recognized as separate biogeographic units, based on the biocenotic and landscape criteria. In the context of the biotic approach, an estuary is an area with a wide crowding zone at the marine water/fresh water barrier for species dispersal. These areas extend from the zone with critical or zero salinity to areas with marine salinity inhabited by marine communities. They do not have the status of separate biogeographic (biotic) units. A narrow crowding zone always occurs along the continental coast because the land/sea border is a very efficient barrier for species dispersal. But this crowding zone widens in areas of large river mouths where fresh water is mixed with seawater at a distance from land. In such areas the limits of species ranges of some marine species are displaced into the open ocean, to a degree depending on the individual species tolerance to low salinity (Fig. 21). The more stenohaline is a marine species, the more distant from the mainland is the species range limit. 


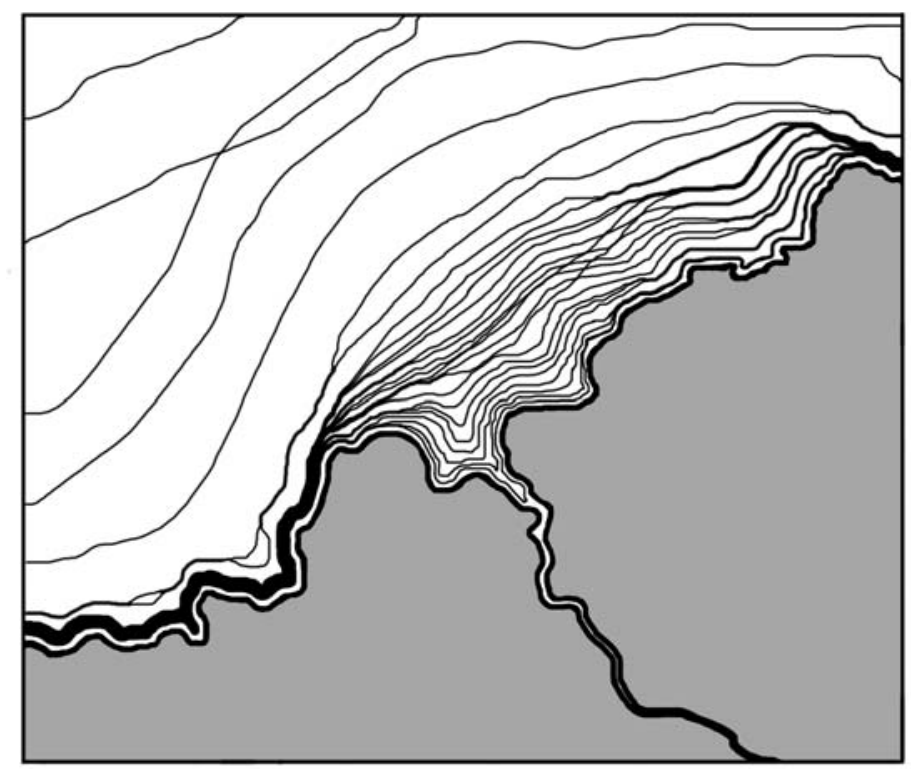

Fig. 21. Hypothetical scheme showing a narrow crowding zone at the barrier water/land and its widening in the estuarine area. The lines designate the northern borders of species ranges.

Рис. 21. Гипотетическая схема, показывающая узкую зону сгущения вблизи барьера вода/суша и ее расширение в эстуарном районе. Линии обозначают северные границы распространения видов.

\subsection{Deep-sea basins}

Menzies etal.(1973:322) proposed a scheme for the division of the Arctic abyssal. The Arctic Deep-Water Region (with the upper limit in the High Arctic at about $425 \mathrm{~m}$ depth) was divided into five provinces: the Norwegian, GreenlandFram, Eurasian, Siberian and Canadian, based on biotic and landscape criteria. The authors used "where possible, temperature as well as topography as determinants for province definitions".

Watling et al. (2013) recognize the Arctic Province in the lower bathyal zone $(>800 \mathrm{~m})$ and Basin Arctic Province in the abyssal zone. The authors used the landscape approach to regionalization: the proposed provinces are characterized by them as based strongly on watermass characteristics defined by temperature and salinity signals and POC flux characteristics, defined by food availability in these detritusbased deep-sea ecosystems. However the landscape approach allows the subdivision of the deep-sea Arctic into several provinces. A single abyssal province in the Arctic Ocean is usually a result of the biotic regionalization.

\subsection{Hydrothermal vent fields}

Tyler and Young (2003) considered the little-explored Arctic as a "potential" hydrothermal province. Recently hydrothermal vent fauna has been discovered in the Arctic deep-sea. Hydrothermal fields were found along the Arctic Mid-Ocean Ridge, off the Jan Mayen Island, at 500-750 m depth (Schander et al., 2010) and at Loki's Castle, $2400 \mathrm{~m}$ depth (Pedersen et al., 2010; Rapp et al., 2011). According to Rapp et al. (2011: 121), the "Loki Castle vent field hosts an endemic fauna composed of specialized polychaetes, gastropods, amphipods and fish. The high degree of local adaptation and specialization of fauna from the studied sites allows us to propose the Arctic Mid-Ocean Ridge to be a new zoogeographical province for vent fauna". The methods of biogeography used for hydrothermal areas contradict the basic concepts of the biotic approach and follow the biocenotic approach: (1) species ranges are regarded as interrupted, (2) species with different ecologies (vent and non-vent) have unequal weight, (3) differences between faunas of small areas are 
taken into account and cluster analysis is used to reveal the biogeographic units, (4) the zone of crowding is not a criterion for drawing a biogeographic boundary (compare with Table 1). In addition the environmental data are taken into account at the stage of initial regionalization, this feature is typical of the landscape approach.

The term "endemic" is used in the biotic biogeography to define the purely chorological notion. A species is endemic of a region if it is not found outside this region. The region size and ecological peculiarities of species and environment are of no importance. In the biogeography of hydrothermal fauna this term is used in another sence: a species is "vent endemic" if it is not found in the non-hydrothermal environment. To avoid the semantic confusion, the term "vent obligate" should be used for species only found surrounding a hydrothermal vent (Mironov et al., 1998, 2002; Tarasov et al., 2005).

Biogeographic regionalization related to hydrothermal vent fauna usually disregards regionalization of the background fauna (Tunnicliffe, 1998; Van Dover et al., 2002; Bachraty et al., 2009). Mironov et al. (1998, 2002) compared the geographic distribution of deep-sea species occurring on hydrothermal fields with species in the regular deep-sea environment. It appeared that the distribution of hydrothermal vent species basically corresponds to biotic divisions of the regular (non-hydrothermal) environment. Therefore Mironov et al. (1998, 2002) suggested that the biogeographic organization of the two faunas is controlled by the same factors, and the biotic regionalization should be universal for hydrothermal and background faunas.

Species inhabiting vent fields and adjacent non-vent areas belong to one and the same biotic complex. Schemes of biotic regionalization can predict faunistic differences between hydrothermal vent areas. Thus, the deep-sea Arctic Ocean in biotic schemes is separated from the deep-sea North Atlantic; therefore the fauna of Arctic hydrothermal fields is expected to differ from the Atlantic vent fields.

\section{Latitudinal biotic zones}

Plotting biotic zones is part of causal analysis. It is performed after the boundaries of biotic regions have been revealed using the chorological (areographic) approach. A biotic zone consists of biotic regions combined into a zonal belt (latitudinal, vertical or circum-continental) based on the similarity of zonal environmental characteristics of these regions (Mironov, 1990, 1999). The similarity of biota (fauna and flora) of biotic regions is not important for combining regions into one zone. For example, the sublittoral zone includes the low-latitude and the high-latitude regions with drastically different biota, although both zones are located in the photic zone. Environmental data is excluded when revealing boundaries of biotic zones, since these boundaries are the same as in biotic regions. Biotic zones demonstrate the latitudinal extension of some biogeographic boundaries.

The two latitudinal biotic zones, the boreal and the arctic, are recognized on the shelf of the Arctic Ocean. The biotic boundaries in the Arctic Ocean approximately correspond to summer isotherms of surface waters. The boundary of the North Polar Shelf Subregion correlates with the summer surface temperature from 6 to $8^{\circ} \mathrm{C}$, according to the Atlas of the Arctic, map VIII.14 (Treshnikov, 1985) (also see AMAP, 1998). The arctic biotic zone is defined as the group of biotic regions (the American-Eurasian and the Chukchi-American Provinces) with the summer surface $\mathrm{T}<4^{\circ} \mathrm{C}$. The boreal zone is defined as the group of biotic regions (the Eastern Atlantic, the Western Atlantic, the Eastern Pacific and the Western Pacific Regions) with a summer surface temperature about $8^{\circ} \mathrm{C}$ in its northern areas. Most of the boreal zone is outside the Arctic Ocean and includes only a small part of the Arctic shallow waters - the Norwegian shelf (Fig. 9).

The wide biotic boundaries between the North Polar and the North Atlantic regions and between the North Polar and the North Pacific regions can be designated as the subarctic latitudinal subzone. Biotic biogeography does not provide any other possibility for the isolation of the subarctic subzone. Dunbar (1953) defined the subarctic zone as marine areas with the upper water layers of mixed polar and non-polar origin. The subarctic zone of Dunbar (1953, Fig. 1) coincides approximately with the wide crowding zone outlining the North Polar Region. Zimmer $(1900,1904)$, apparently, was the first to separate the transitional Subarctic Region (zone) 
extending from the Lofoten Islands to the Eastern Murman in the south Barents Sea. The width of the subarctic zone, or subzone, varies depending on the concept. The approach of Hunt and Drinkwater (2005) is an example of a broad understanding of the zone of "the Sub-Arctic Seas". It spans northward to Hudson Bay (inclusive) and in the Pacific it completely covers the Bering and Okhotsk Seas. According to Schmidt (1904), the Subarctic Transition Region is a narrow zone with southern position: in the Atlantic Ocean south to Nova Scotia and in the Pacific Ocean south to the Korean Peninsula.

In history of the Arctic Ocean biogeography, numerous, varied schemes of zonal regionalization have been produced, most with confusion of the hierarchical and zonal characteristics of delineated areas. The present paper does not aim to critical review these schemes. We compare only biotic zones with biomes based on the biocenotic approach. The term "biome" was introduced by Clements (1916). Biome designates a group of related communities (Clemens, 1916; Udvardy, 1969; Mirkin et al., 2002) or the largest community unit (Odum, 1971; Longhurst, 1998). Biome was described and characterized by climax, rather than by succession, communities. Kendeigh(1961) defined "biome" as a community distinguished by life forms of important climax species. According to Odum (1971), the life forms of the climatic climax vegetation are uniform in a given biome. Major terrestrial biomes (tundra, boreal forest, temperate deciduous forest, temperate rain forest, subtropical evergreen forest, temperate grasslands, deserts and others) are extended latitudinally.

In publications on marine biota, "biome" has been given different meanings, resulting in confusion (Pielou, 1979; Brown, Lomolimo, 1998; Longhurst, 1998; Petrov, 2009 etc.). Up to now, there has been no agreement among biogeographers about the definition and number of biomes in the World Ocean. Regions recognized as biomes usually do not extend latitudinally. For example, Pielou (1979) distinguished "proper marine" biomes (Coral reef, Deep sea benthos, Pelagic plankton, Pelagic nekton and Neuston) and littoral biomes (Rocky shore, Sandy shore, Muddy shore and saltmarsh and Shallow sea benthos). Pielow (1979) emphasized that "a world map showing ecological biomes needs to be printed on a large scale and in colour if it is to be legible, since biomes are defined only by their ecological properties and may occupy a space made up of numerous small, scattered fragments".

With rare exceptions, there are no such groups of communities on the ocean floor that would form global latitudinal zones and could be easily recognized by characteristic group of related species. One exception is coral reefs. Therefore, applying the concept of biome to benthic marine biota requires a fundamental change of the concept.

The marine pelagic biomes of Longhurst (1998) are latitudinally extended, similar to terrestrial biomes. The pelagic World Ocean in this scheme is divided into 51 biogeographic provinces combined into 12 biomes. Boundaries of many provinces and biomes are similar to borders of biotic divisions suggested by Briggs $(1974,1995)$. Boundaries of the Atlantic Polar Biome approximately correspond to those of the North Polar Shelf Subregion and the arctic biotic zone on Fig. 9. Longhurst (1998) pointed out that identification of ecological biomes and provinces basically rests on observed, or inferred, regional discontinuities in physical processes, particularly those affecting the stability of the upper kilometre of the ocean or the mixing of deeper water into the photic zone. Regional differences in other ecologically significant variables, such as light and illumination of the nutricline, were also considered. Thus Longhurst basically used the landscape approach to regionalization. However, the results of the biogeographic analysis by Longhurst rather suggest the biotic approach, and his biomes approximately correspond to biotic latitudinal zones.

\section{Arctic biotic complexes and large ecosystems}

The biogeocomplex concept suggests the coincidence of biotic boundaries with drastic changes of environmental physical-chemical parameters and with boundaries of the landscape-biocenotic regions (see Section 3). The boundaries of the Arctic biotic regions demonstrate good correlation with environmental heterogeneity. For example, the Greenland-Iceland-Faeroe Ridge plays an obvious role in separating water masses of different origin: the warmer more saline Atlantic waters and the 
cooler Polar waters with lower salinity (Meincke, 1983; Hansen, Østerhus, 2000). The cold East Greenland Current with two major branches, the Jan Mayen Current and the East Icelandic Current, dominates the western part of the Nordic Seas. The East Icelandic Current flows along the North Icelandic slope into the southwest Norwegian Basin. There is the Arctic Front over the northern slope of the Iceland-Faeroe Ridge, also known as the Iceland-Faeroe Front, as it mixes with the Atlantic Waters of the Faeroe Current (Hansen, Østerhus, 2000; Blindheim, Rey, 2004). The boundary of the North Polar Region follows the Greenland-Iceland-Faeroe Ridge. Brix and Svavarsson (2010) suggested that the Greenland-Iceland-Faeroe Ridge per se might act as secondary barrier, however the authors mentioned that the ridge shapes the temperatures of the area. Most species are restricted to either cold or warm water masses.

Warm Atlantic currents disrupt the coincidence of biotic and geomorphological boundaries in the eastern part of the Greenland-Iceland-Faeroe Ridge. The Atlantic waters penetrate the Arctic mainly through the IcelandFaeroe Trough, flowing northward along the Norwegian slope as the warm Norwegian Current (Klepikov et al., 1985; Mauritzen, 1996; Mork, Blindheim, 2000; Ersdal, 2001; Jones, 2001). North of $70^{\circ} \mathrm{N}$, the Norwegian Current divides into the West-Spitsbergen and the Nordcap Currents. The former tightly adheres to the Spitsbergen slope and enters the Arctic Basin through the Fram Strait. The Nordcap Current skirts the Scandinavian Peninsula and enters the Barents Sea. The boundary between the boreal and arctic biotas closely follows the warm currents: it curves northward along the Norwegian slope, stretching up to the western Barents Sea and Spitsbergen.

Cold Arctic currents offset the biotic boundary from the geomorphological barrier in the western part of the Greenland-Iceland-Faeroe Ridge. Cold Arctic waters flow southward along the western and eastern slopes of Greenland and along coasts of the North America. These waters penetrate the Atlantic through the Denmark, Davis and Hudson straits. A wide crowding zone of species range boundaries also spreads southward following the cold waters to Newfoundland.

The number of biogeographic regions on the Arctic shelf increases from schemes based on the biotic approach to those based on mixed elements of biotic and biocenotic approaches, and increases further in schemes based on biocenotic, landscape and mixed biocenotic-landscape approaches. The strictly biotic approach recognizes only three subdivisions on the Arctic shelf (Fig. 9) and the single subdivision in the Arctic deep sea. Summing up the maximum numbers of subdivisions revealed in Arctic seas using the landscape-biocenotic approach, the Arctic Ocean appears to be divided into more than 50 biogeographic regions. A group of small landscape-biocenotic regions falls into one large biotic province.

The biotic boundaries in the Arctic Ocean are very wide - up to several hundred $\mathrm{km}$, whereas the landscape-biocenotic boundaries are linear. Some landscape-biocenotic provinces fall entirely into the crowding zones. It seems likely that communities of wide crowding zones have unique structure and succession. In other words, a wide crowding zone can be marked by unique structure and succession of communities transitional between communities of adjacent biotic provinces. For example, Anisimova (2000b) divided the Barents Sea into nine biocenotic regions, four of them transitional between the boreal and arctic faunas. The transitional regions lie in the crowding zone or near it (compare Figs 9 and 16). Denisenko (2008) showed the substantial width of the biogeographic boundary in the Barents Sea using the biocenotic approach. He studied the ratio of the boreal and arctic species and the ratio of their biomasses. In either case it followed that the transition zone in the Barents Sea is wide and its borders correspond to the position of fields with temperature gradients of more than $2^{\circ} \mathrm{C}$. The crowding zones in the estuarine areas are well marked by biocenotic brackish-water provinces.

However, successional processes in marine benthic communities are not well studied and methods of biocenotic regionalization are not advanced enough to reveal in space a succession system and estimate its' correspondence to a crowding zone or to a biotic complex. Methods of distinguishing and outlining communities from one succession system need to be improved.

The results of the biogeographic regionalization of the Arctic Ocean support the hypothesis that a biotic complex is a large universal structural-functional unit of a living realm. In 
theory any biotic boundary can be revealed by different approaches to biogeographical regionalization at the large scale: biotic, biocenotic and landscape. On the other hand, most biogeographic boundaries revealed by biocenotic and landscape approaches are not biotic boundaries.

\section{Crowding effect of adaptations}

Factors controlling the crowding zones are different in different areas. Physical factors play the leading role in the development of crowding zones at the border between the sea and the land, or between seawater and fresh water. Effective physical barriers to dispersal seldom exist in marine systems and the prevalence of planktonic larvae in marine benthic taxa provides a potential for gene flow across large geographic distances. This raises the fundamental question in biotic biogeography - can partial oceanographic barriers alone account for the zones of crowding?

In the evolution of the crowding zones three main stages have been suggested (Mironov, 2002, 2004). At the first stage (autecological), the species range limits are set by partial or "porous" (Rapoport, 1982) environmental barriers to dispersal. It is mainly physiological tolerance that allows some species to disperse further than others. At this stage, the succession system of communities at both sides of a weakly expressed crowding zone is one and the same (uniform). At the second stage (synecological) interspecies interactions and adaptations lead to evolutionary stable species range limits even with no barriers to gene flow. Dispersal barriers at this stage synchronise range limits of interacting species. Without interactions, species range limits would be driven by non-biological (abiotic) environmental factors. The correlation between species range limits and species interactions is discussed in numerous publications (Gaston, 2003; Parmesan et al., 2005; Holt, Barfield, 2009; Price, Kirkpatrick, 2009, etc.). With maturation of a crowding zone, the number of species range limits in the zone increases and distances between them decrease.

At the third stage (ecosystem), a previously uniform succession system (common at both sides of a crowding zone) becomes differentiated into two systems. "Cenophilic" species coadapt to biotic conditions in one succession (cenotic) system, and this prevents their immi- gration to adjacent succession system in which different adaptations are required. Thus, a mature succession system or biotic complex enforces advantages of adaptations to local environment and decreases probability of dispersal of cenophilic species beyond a crowding zone. At this stage, barriers to dispersal synchronise range limits of species from one succession system (Fig. 22). Mironov (2002, 2004) suggested calling the gradual convergence of range limits as a result of co-adaptations of cenophilic species the "crowding effect of adaptations". This implies that a crowding zone can be a much more effective barrier to dispersal than a physical barrier in a given zone. The barrier effect of a crowding zone gradually increases owing to exclusively biotic changes and through the evolution of a biotic complex.

Mironov and Dilman (2010) suggested that the great width of crowding zones in the Arctic indicates their young age. Co-adaptations and succession systems in the Arctic biotic complexes are insufficiently developed to form narrow and effective crowding zones. The young age of crowding zones in the Arctic may result from the young geological age of the Arctic environment. The warm Tertiary period was followed by the cooler Quaternary, with a set of glacial episodes during the Pleistocene. The relatively stable environment has established in the Arctic only after the last glaciation, about 10000 years ago. This period of time was apparently too short for the formation of mature biotic complexes and efficient biotic dispersal barriers.

\section{Acknowledgements}

The author thanks Alexandr Sysoev for constructive review of the manuscript and Alexandr Gukov for the scheme of biogeographic division of the Laptev Sea. This work is part of the project "Arctic marine fauna: data accumulated in Russia" (sub-project of the CoML "Arctic Ocean Diversity" program). The work was in part supported by the Grant 8664 of Minobrnauki, Russian Federation.

\section{References}

AMAP. 1998. AMAP Assessment Report: Arctic Pollution Issues: Physical/Geographical Characteristics of the Arctic. Oslo: Arctic Monitoring and Assessment Program (AMAP). 859 p. 

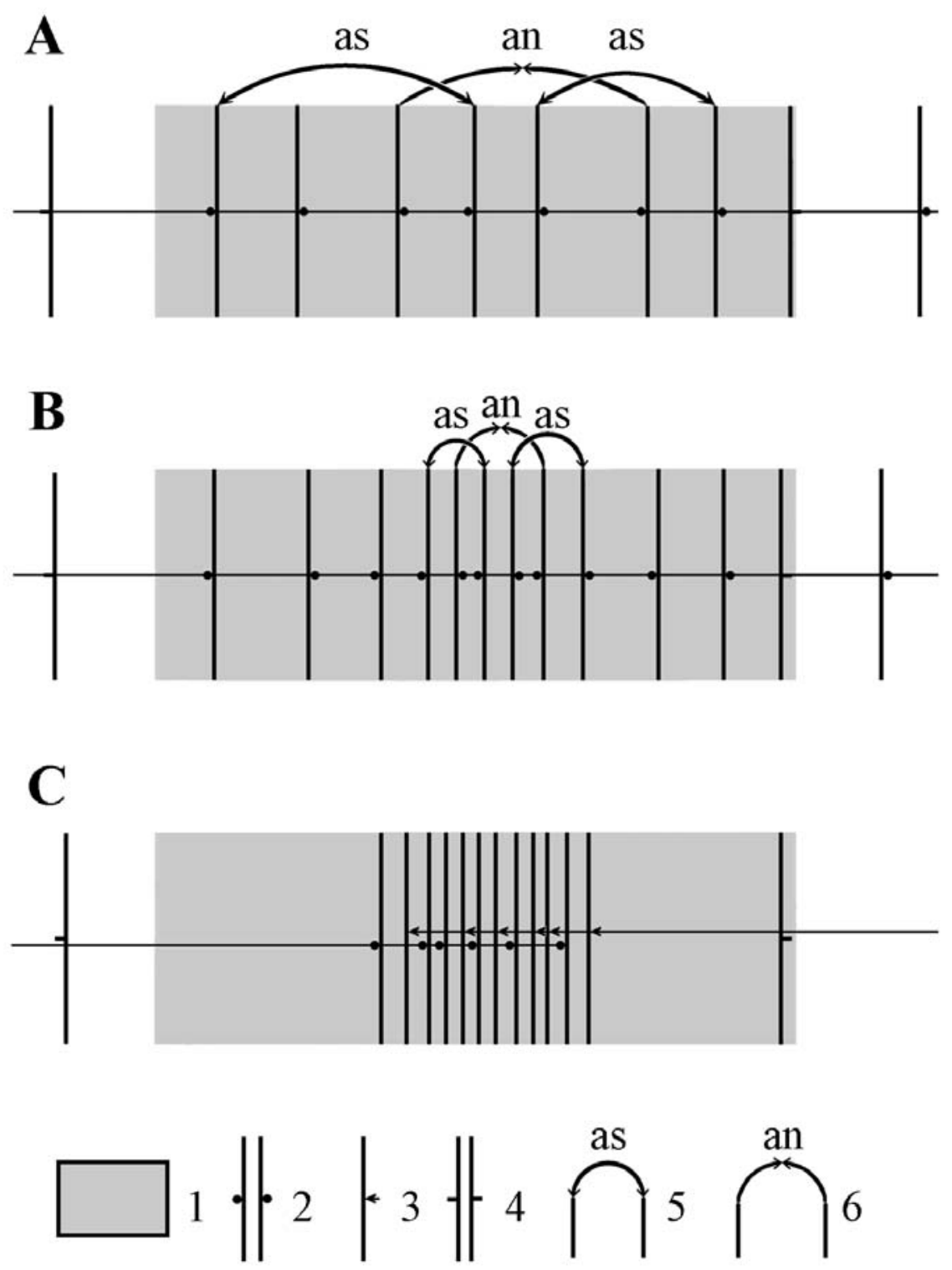

Fig. 22. Three stages of evolution of a crowding zone (crowding effect of adaptations). A - Autecological stage, B - Synecological stage, C - Ecosystem stage (explanations in text). 1 - zone of rapid changes of environmental physical parameters, 2 - eastern and western borders of the species ranges from initial succession system, 3 - western border of the species range from new succession system, 4 - eastern and western borders of a cenophobic species ranges, 5- pair of associate species, 6 - pair of antagonistic species.

Рис. 22. Три стадии эволюции зоны сгущения (группирующий эффект адаптаций).

А - аутэкологическая стадия; В - синэкологическая стадия; С - экосистемная стадия (см. пояснения в тексте). 1 - зона быстрых изменений физических параметров среды, 2 - восточная и западная границы ареалов видов, входящих в состав исходной сукцессионной системы, 3 - западная граница ареала вида, входящего в состав новой сукцессионной системы, 4 - восточная и западная границы ценофобных видов, 5 - пара ассоциативных видов, 6 - пара видов с антогонистическими отношениями. 
Andriyashev A.P., Shaposhnikov G.X. 1985. [Schemes of zoogeographical subdivisions of marine and freshwater fish fauna] // A.F. Treshnikov (ed). Atlas of the Arctic. Moscow: Main Department of geodesy and cartography of the Council of Ministers USSR. Map XI.25. P.133 [in Russian].

Anisimova N.A. 1989. Distribution patterns of echinoderms in the Eurasian sector of the Arctic Ocean // Y. Herman (ed). The Arctic Seas. New York: Van Nostrand. P.281-301.

Anisimova N.A. 2000a. [Crustaceans of the bays and gulfs on the southern part of the Pechora and the Kara seas] // G.G. Matishov (ed.). Current Benthos of the Barents and the Kara seas. Apatity: Kola Science Centre RAS. P.115-156 [in Russian, English abstract].

Anisimova N.A. 2000b. [Echinoderms of the Barents Sea. Biogeographical analysis of the fauna]// G.G. Matishov (ed.). Current Benthos of the Barents and the Kara seas. Apatity: Kola Science Centre RAS. P.237255 [in Russian, English abstract].

Anisimova N.A. 2003. [Echinoderms of the southern part of the Kara Sea (on results of the quintitative collections 1993-1994)] // G.G. Matishov (ed.). Fauna of the invertebrates of the Barents, the Kara and the White Seas (information technologies, ecology, biogeography). Apatity: Kola Science Centre RAS. P.111130 [in Russian].

Antipova T.V., Semenov V.N. 1989. [Benthic Biocenoses of the Southwestern Areas of the Kara Sea] //Ecologiya i bioresursy Karskogo moray [Ecology and Biological Resources of the Kara Sea]. Apatity: Kola Science Centre AN SSSR. P.138-145 [in Russian].

Appellöf A. 1912. Invertebrate bottom fauna of the Norwegian Sea and North Atlantic // Depths of the Ocean. London: MacMillian and Co., Limited. P.457-560.

Arzamascev I.S., Preobrazhensky B.V. 1990. [Atlas of underwater landscapes of the Sea of Japan]. Moscow: Nauka. 224 p. [in Russian].

Audzijonytë A. 2006. Diversity and zoogeography of continental mysid crustaceans // Walter and Andrée de Nottbeck Foundation Scientific Reports. Vol.28. P.1-46.

Bachraty C., Legendre P., Desbruyères D. 2009. Biogeographic relationships among deep-sea hydrothermal vent faunas at global scale // Deep-Sea Research I. Vol.56. P.1371-1378.

Beklemishev K.V. 1969. [Ecology and biogeography of the pelagial]. Moscow Nauka Press. 291 p. [in Russian].

Beklemishev K.V. 1982. [About the nature of biogeographical evidences] // O.G. Kussakin (ed.). Marine biogeography: Subject, methods, and principles of regionalization. Moscow: Nauka Press. P.5-11 [in Russian].

Belyaev G.M. 1989. [Deep-Sea Ocean Trenches and Their Fauna]. Moscow: Nauka Publishing House. 385 p. [in Russian; translated to English by Scripps Institution of Oceanography, USA, 2004].

Bilyard A.G., Carey G.R., Jr. 1980. Zoogeography of western Beaufort Sea Polychaeta (Annelida) // Sarsia. Vol.65. P.19-26.

Blindheim J., Rey F. 2004. Water-mass formation and distribution in the Nordic Seas during the 1990s // ICES Journal of Marine Science. Vol.61. P.846-863.

Bluhm A.B., Ambrose W.G., Jr., Bergmann M., Clough L.M., Gebruk A.V., Hasemann C., Iken K., Klages M.,
MacDonald I.R., Renaud P.E., Schewe I., Soltwedel T., Włodarska-Kowalczuk M. 2011. Diversity of the arctic deep-sea benthos// Marine Biodiversity. Vol.41. No.1. P.87-107.

Bogdanov I.P. 1994. [Gastropods Oenopotinae of the East Siberian Sea] // Issledovaniya fauny morei [Explorations of the fauna of the seas]. Vol. 49(57). P.123-130 [in Russian].

Boltovskoy E., Wtight R. 1976. Recent Foraminifera. The Hague: Dr. W. Junk Publisher. 515 p.

Bouchet P., Warén A. 1979. The abyssal molluscan fauna of the Norwegian Sea and its relation of other faunas // Sarsia. Vol.64. P.211-243.

Brandt A. 1997. Abundance, diversity and community patterns of epibenthic- and benthic-boundary layer peracarid crustaceans at $75^{\circ} \mathrm{N}$ off East Greenland // Polar Biology. Vol.17. P.159-174.

Brattegard T., Holthe T. (eds.). 1997. Distribution of marine, benthic macroorganisms in Norway. Trondheim, Norway: Research Report for DN 1997-1. Directorate for Nature Management. $409 \mathrm{p}$.

Briggs J.C. 1974. Marine Zoogeography. New York: McGraw-Hill Book Co. 475 p.

Briggs J.C. 1995. Global Biogeography. Amsterdam: Elsevier. $452 \mathrm{p}$.

Brix S., Svavarsson J. 2010. Distribution and diversity of desmosomatid and nannoniscid isopods (Crustacea) on the Greenland-Iceland-Faeroe Ridge // Polar Biology. Vol.33. P.515-530.

Brown J.H., Lomolimo M.V. 1998. Biogeography. 2nd edition. Sunderland, Massachusetts: Sinauer Associates, Inc. $691 \mathrm{p}$.

Buhanan R., Sekerak A.D. 1982. Vertical distribution of zooplankton in Eastern Lancaster Sound and Western Baffin Bay, July - October 1978 // Arctic. Vol.35. No.1. P.41-55.

Chernov Yu.I. 1984. [Flora, fauna, vegetation and animal population] // Zhurnal obshchey biologii [Journal of General Biology]. Vol. 45. No.6. P.732-748 [in Russian].

Chernova N.V. 2011. Distribution patterns and chorological analysis of fish fauna of the Arctic region // Journal of Ichthyology. Vol.51. No.10. P. 825-924.

Clarke A. 2003. The polar deep seas // P.A. Tyler (ed). Ecosystems of the Deep Oceans. Amsterdam: Elsevier. P.239-260.

Clements F. 1916. Plant succession: analysis of the development of vegetation // Carnegie Instution of Washington, Publication. Vol.242. P.1-512.

Cook R.R., Auster P.J. 2007. A bioregional classification of the continental shelf of northeastern North America for conservation analysis and planning based on representation. Marine Sanctuaries Conservation Series, NMSP07-03. U.S. Department of Commerce, National Oceanic and Atmospheric Administration, National Marine Sanctuary Program, Silver Spring, MD. 14 p.

Dana J.D. 1853. On an isothermal oceanic chart illustrating the geographical distribution of marine animals // The American Journal of Science and Arts. Ser. 2. Vol.16. No.47. P.153-167.

Dauvin J.C., Alizier S., Weppe A., Guðmundsson G. 2012. Diversity and zoogeography of Icelandic deep-sea Ampeliscidae (Crustacea: Amphipoda) // Deep-Sea Research I. Vol. 68. P.12-23. 
De Lattin G. 1967. Grundriss der Zoogeographie. Jena: VEB Gustav Fisher Verlag. 602 S.

Denisenko N.V., Rachor E., Denisenko S.G. 2003. Benthic fauna of the southern Kara Sea // Proceeding in Marine Science. Vol.6. P.213- 236.

Denisenko S.G. 2008. [Macrozoobenthos of the Barents Sea in conditions of changing climate and anthropogenic influence]. Doctoral dissertation in Biological Science. Saint-Petersburg: Zoological Institute of Russian Acad. Sci. 465 p. [in Russian]

Derjugin K.M. 1915. [Fauna of the Kola Bay and the conditions of its existence] // Mémoires de l'Acadedémie Impériale des Sciences de Petrograd. VIII Série, Classe Physico-mathétique. Vol.34. No.1. P.1-929 [in Russian].

Deubel H., Engel M., Fetzer I., Gagayev S., Hirche H.-J., Klages M., Larionov V., Lubin P., Lubina O., Nöthig E.-M., Okolodkov Y., Rachor E. 2003. The Kara Sea ecosystem: phytoplankton, zooplankton and benthos communities influenced by river run-off// R. Stein, K. Fahl, D.K. Fütterer, E.M. Galimov, O.V. Stephanets (eds.). Siberian river run-off in the Kara Sea. Characterisation, quantification, variability and environmental significance. Amsterdam: Elsevier. P.237-266.

Dilman A.B. 2009. [Biogeography of the asteroids of the North Atlantic and Arctic]. Ph. D. thesis. Moscow: Institute of oceanology of the Russian Acad. Sci. 214 p. [in Russian].

Dinter W.P. 2001. Biogeography of the OSPAR Maritime Area. Bonn, Germany. 167 p.

Drude O. 1890. Handbuch der Pflanzengeographie. Stuttgard: Engelharn. $582 \mathrm{~S}$.

Dunbar M.J. 1953. Arctic and subarctic marine ecology: immediate problems // Arctic. Vol.6. No.2. P.75-90.

Dunbar M.J. 1972. The nature and definition of the marine subarctic, with a note on the sea-life of the Atlantic Salmon // Transactions of the Royal Society of Canada. Series IV. Vol.10. P.249-357.

Dunbar M.J. 1979. The relation between the oceans // Van der Spoe, A.C. Pierrot-Bults (ed.). Zoogeography and Diversity of Plankton. London - Utrecht: Edward Arnold, Bunge Scientific Publ. P.112-125.

Dunbar M.J. 1988. Marine regional boundaries in the Canadian North: Foxe Basin, Hudson Strait, Hudson and James Bay. Ottawa, Canada: Dunbar Environmental and Arctic Consultants. Report for Canadian Park Service. $43 \mathrm{p}$.

Ekman S. 1953. Zoogeography of the sea. London: Sidgwick and Jackson. 417 p.

Emson R.H., Tyler P.A., Norrevang A. 1994. Distribution of bathyal ophiuroids round the Faroes in relation to the local hydrodinamic regime // B. David, A. Guille, J.-P. Feral, M. Roux (eds). Echinoderms through time. Rotterdam: Brookfield, A.A. Balkema. P.411-418.

Ersdal G. 2001. An overview of ocean currents with emphasis on currents on the Norwegian continental shelf // NPD Preliminary Report. March 2001. P.140.

Evans F.C. 1956. Ecosystem as the basic unit of ecology // Science. Vol.123. No.320. P.153-167.

Fedyakov V.V. 1980. [Some pecualirities of distribution patterns of the bivalves in the White Sea] // Biologia morya [Russian Journal of Marine biology]. Vol.5. P.15-19 [in Russian, English abstract].
Fedyakov V.V., Naumov A.D. 1989. Marine Bivalvia of the Arctic Ocean // Y. Herman (ed). The Arctic Seas. New York: Van Nostrand. P.303-324.

Fetzer I., Hirche H.J., Kolosova E.G. 2002. The influence of freshwater discharge on the distribution of zooplankton in the southern Kara Sea // Polar Biology. Vol.25. P.404-415.

Filatova Z.A. 1957. [Zoogeographical division of northern seas (by distribution of Bivalvia)] // Trudy Instituta Okeanologii [Transactions of the Institute of Oceanology]. Vol.23. P.195-215 [in Russian].

Filatova Z.A. 1962. Bivalve molluscs of the Northern seas of Eurasia and the zoogeographical division of the Arctic// Proceedings of the 1st European Malacological Congress, London, 1962. London: Conchological Society of Great Britain and Ireland and the Malacological Society of London. P.37-43.

Filatova Z., Zenkevitch L. 1957. [Quantitative distribution of the fauna in the Kara Sea] // Trudy Vsesoyuznogo Okeanologicheskogo Obschestva. Vol.8. P.3-67 [in Russian].

Forbes E. 1856. Map of the distribution of marine life, illustrated chiefly by fishes, molluscs and radiata; showing also the extend and limits of the homoiozoic belts //A.K. Johnston (ed.). The physical atlas of natural phenomena, Edinburg, London: W. a. A.K. Johnston. Pl. 31.

Frolova E.A. 2003. [Polychaetes of the southern part of the Kara Sea] // G.G. Matishov (ed.). [Fauna of the invertebrates of the Barents, the Kara and the White Seas (information technologies, ecology, biogeography)]. Apatity: Kola Science Centre RAS. P.92-111 [in Russian].

Frolova E.A. 2009. [Fauna and ecology of polychaete (Polychaeta) in the Kara Sea]. Apatity: Kola Science Centre Russian Acad. Sci. 141 p. [in Russian, English abstract].

Fütterer D.K., Galimov E.M. 2003. Siberian rover run-off in the Kara Sea: Characterisation, quantification, variability and environmental significance - An introduction // Proceeding in Marine Science. Vol.6. P.1-8.

Gagaev S.Y., Deubel H., Fetzer I., Rachor E. 2006. Polychaete community structure of the southern Kara Sea // Issledovaniya fauny morei [Exploration of the Fauna of the Sea]. Vol.56(64). P.63-78.

Galkin S.V., Kucheruk N.V., Minin K.V., Rayskiy A.K., Goroslavskaya E.I. 2010. [Macrobenthos of the Ob River estuarine zone and of the adjacent regions of the Kara Sea]//Okeanologia [Oceanology]. Vol.50. No.5. P.793-797 [In Russian, English abstract].

Gardiner F.P., Haedrich R.L. 1978. Zonation in the deep benthic megafauna; application of a general test // Oecologia. Vol.31. P.311-317.

Gaston K.J. 2003. The structure and dynamics of geographic ranges. Oxford, UK: Oxford University Press. $266 \mathrm{p}$.

Golikov A.N. 1980. [Mollusca Buccininae of the World Ocean] // Fauna SSSR [Fauna of the USSR]. Novaya Seriya Is.85. Mollusca. Vol.5. No.2. 508 p. [in Russian].

Golikov A.N., Dolgolenko M.A., Maximovich N.V., Scarlato O.A. 1990. Theoretical approaches to marine biogeography // Marine Ecology Progress Series. Vol.63. P.289-301. 
Golikov A.N., Scarlato O.A. 1989. Evolution of Arctic ecosystems during the Neogene period // Y. Herman (ed.). The Arctic Seas. New York: Van Nostrand. P.257-279.

Gontar V.I., Denisenko N.V. 1989. Arctic Ocean Bryozoa // Y. Herman (ed.). The Arctic Seas. New York: Van Nostrand. P.341-371.

Gorbunov G.P. 1941. [Bivalve mollusc Portlandia arctica (Gray), as an index of distribution of continental waters in Siberian seas] // Problemy Arktiki [Arctic Problems]. Vol.11. P.46-55 [in Russian].

Gorbunov G.P 1946. [Bottom life of the Novosiberian shoalwaters and the central part of the Arctic Ocean] // Trudy dreifuyustchei ekspeditsii Glavsevmorputi na ledokolnom parokhode "G. Sedov" 1937-1940 [Transactions of the Drifting expedition Glavsevmorput on the ice-breaker "G. Sedov" 1937-1940] Vol.3. P.30-138 [in Russian, English summary].

Grainger E.H. 1966. Sea stars (Echinodermata: Asteroidea) of arctic North America // Bulletins of the Fisheries Research Board of Canada. Vol.152. P.1-70.

Green J. 1961. A Biology of Crustacea. London: H.F. \& G. Witherby Ltd. $180 \mathrm{p}$

Gukov A.Yu. 1999. [Ecosystem of the Siberian Polynya]. Moscow: Nauchniy mir. 334 p.[in Russian, English abstract].

Gukov A.Yu. 2001. [Hydrobiologie of the Lena mouth area]. Moscow: Nauchniy mir. 288 p. [in Russian, English abstract].

Gurjanova E.F. 1951. [Side-swimmers of the Seas of the USSR and adjacent waters (Amphipoda-Gammaridea)] // Opredeliteli po faune SSSR [Keys to the fauna of the USSR]. Vol.41. P.1-1029 [in Russian].

Hagmeiner E.M., Stults C.D. 1964. A numerical analysis of the distributional patterns of North American mammals // Systematic Zoology. Vol.13. P.125-155.

Hansen B., Østerhus S. 2000. North Atlantic-Nordic Seas exchanges // Progress in Oceanography. Vol.45.P.109208.

Hedgpeth J.W. 1957. Classification of marine environments // Geological Society of America, Memoir. Vol.67. No.1. P.17-27 (Treatise on marine ecology and paleontology).

Hedgpeth J.W. 1963. Pycnogonida of the North American Arctic // Journal of the Fisheries Research Board of Canada. Vol.20. No.5. P.1315-1348.

Heptner V.G. 1936. [General zoogeography]. Moscow Leningrad: Biomedgiz. 548 p. [in Russian].

Herzenstein S.M. 1885. [Data on the fauna of the Murmansk coast and the White Sea. 1. Molluscs] // Trudi Sankt-Peterburgskogo Imperatorskogo Obshchestva Estestvoispitateley. Vol. I6. No.2. P.635-814 [in Russian].

Hesse R. 1924. Tiergeographie auf okologischer Grundlage. Jena: G. Fischer. 613 S.

Holt R.D., Barfield M. 2009. Trophic interactions and range limits: the evidence roles of predation // Proceedings of the Royal Society. B. Vol.276. No.1661. P.1435-1442.

Hunt G.L., Jr, Drinkwater K.F. (eds.). 2005. Ecosystem Studies of Sub-Arctic Seas (ESSAS) Science Plan // GLOBEC Report. Vol.19. P.1-60.

Ivanov D.L., Scheltema A.H. 2001. Distribution of known caudofoveate species (Mollusca, Aplacophora) around Iceland // Ruthenica. Vol.11. No.1. P.1-6.
Jakobsson M., Macnab R., Mayer L., Anderson R., Edwards M., Hatzky J., Schenke H. W., Johnson P. 2008. An improved bathymetric portrayal of the Arctic Ocean: Implications for ocean modeling and geological, geophysical and oceanographic analyses // Geophysical Research Letters. Vol.35. No.7. P.1-5.

Jirkov I.A. 2010. [Life on the bottom. Bio-ecology and bio-geography of benthos]. Moscow: KMK Sci. Press. 453 p. [in Russian].

Jirkov I.A. 2013. Biogeography of the Barents Sea benthos // Invertebrate Zoology. Vol.10. No.1. P.69-88.

Jirkov I.A., Leontovich M.K. 2012. Biogeography of Polychaeta of the Eurasian North Polar Basin // Invertebrate Zoology. Vol.9. No.1. P.41-51.

Jirkov I.A., Mironov A.N. 1985. [Contribution to zoogeography of Arctic polychaetes] // Trudy Instituta Okeanologii AN SSSR [Transactions of the P.P. Shirshov Institute of Oceanology of Acad. Sci. USSR]. Vol.120. P.137-151 [in Russian with English abstract].

Jones D.O.B., Bett B.J., Tyler P.A. 2007. Depth-related changes in the arctic epibenthic megafaunal assemblages of Kangerdlugssuaq, East Greenland // Marine Biology Research. Vol.3. P.191-204.

Jones E.P. 2001. Circulation in the Arctic Ocean // Polar Research. Vol.20. No.2. P.139-146.

Kafanov A.I. 1991. [Bivalve molluscs and faunistic biogeography of the Northern Pacific]. Vladivostok: Academy of Sciences of the USSR, Far East Branch. 196 p. [in Russian].

Kafanov A.I. 2005. [Continuity and discontinuity of the Geomerida: the bionomic and biotic aspects] // Journal of General Biology [Zhurnal Obshchey Biologii]. Vol.66. No.1. P.28-54 [in Russian, English abstract].

Kafanov A.I., Kudryashov V.A. 2000. [Marine Biogeography: A Text-book]. Moscow: Nauka. 176 p. [in Russian].

Kendeigh S.C. 1961. Animal ecology. Prentice-Hall: Englewood Cliffs. 468 p.

Khlebovich V.V. 1965. [To physiology of euryhalinity: critical salinity of environment and inner medium] // Voprosy gidrobiologii. Moscow: Nauka. Vyp.1.P.440 441 [in Russian].

Khlebovich V.V. 1974. [Critical Salinity of Biological Processes]. Leningrad: Nauka. 235 p. [in Russian].

Khlebovich V.V. 1986. [On biological typology of estuaries of the Soviet Union] // Trudy Zoologicheskogo Instituta AN SSSR [Proceedings of the Zoological Institute of Acad. Sci. USSR]. Vol.141. P.5-16 [in Russian].

Khlebovich V.V. 1989. [Critical salinity and horohalinicum: contemporary analysis of concepts]. Trudi Zoologicheskogo Institita AN SSSR [Proceedings of the Zoological Institute of Acad. Sci. USSR]. Vol.196. P.5-10 [in Russian].

Kinne O. 1971. Salinity-Animals-Invertebrates // Marine Ecology. Vol.1. Pt.2. London ect.: Wiley-Interscience. P.821-995.

Kiyko O.A., Pogrebov V.B. 1998. Statistical analysis of spatio-temporal structure of the bottom population of the Barents Sea and adjacent waters // Biologiya Morya [Russian Journal of Marine Biology]. Vol. 24. No.1. P.3-9 [in Russian].

Klepikov V.V., Sarukhanyan E.I., Smirnov N.P. 1985. [Peculiarities of hydrology] // A.F. Treshnikov, S.S. Sal'nikov (eds.). The Arctic and Southern Oceans. Leningrad: Nauka. P.65-87 [in Russian]. 
Koltun V.M. 1964. [To studies of bottom fauna of the Greenland Sea and central part of the Arctic Basin] // Trudy Arcticheskogo i Antarkticheskogo NauchnoIssledovatelskogo Instituta [Proceedings of the Arctic and Antarctic Science Research Institute]. Vol.259. P.13-78 [in Russian].

Kosobokova K., Hirche H.-J. 2000. Zooplankton distribution across the Lomonosov Ridge, Arctic Ocean: species inventory, biomass and vertical structure // Deep-Sea Research. Part I. Vol. 47. No.11. P.20292060.

Kosobokova K., Hopcroft R.R. 2010. Diversity and vertical distribution of mesozooplankton in the Arctic's Canada Basin // Deep-Sea Research II. Vol.57. P.92-110.

Kozlovsky V.V. 2012. [Macrozoobenthos of the upper shelf of the south-western Kara Sea]. Ph.D. thesis. Moscow: Institute of oceanology of the Russian Acad. Sci. 117 p. [in Russian].

Krayushkina A.B. 2000. [Geography of the asteroids and holothurians of the Norwegian Sea] // Benthos of the Russian Seas and the Northern Atlantic. Moscow: VNIRO Publishing House. P.41-61 [in Russian, English abstract].

Kulakov M., Pogrebov V., Timofeyev S., Chernova N., Kiyko O. 2004. Ecosystem of the Barents and Kara Seas, coastal segment // The Global Coastal Ocean: Interdisciplinary Regional Studies and Synthesis. Harvard University Press. P.1139-1176.

Kussakin O.G. 1979. [Marine and brackish-water Isopoda of the cold and temperate waters of the Northern Hemisphere. I. Suborder Flabellifera] // Opredeliteli po faune SSSR [Keys to the fauna of U.S.S.R.]. Vol.122. 472 p. [in Russian].

Kuznetsov A.P. 1976. [Trophic structure of the bottom fauna of the Kara Sea] // [Bottom fauna of the marginal seas of the USSR]. Moscow: Institute of Oceanology Acad. Sci. USSR [In Russian].

Kuznetsov B.A. 1936. [Some regularities of mammals distribution in the European part of USSR] // Zoologichesky zhurnal. Vol.40. No.1. P.96-127 [in Russian].

Leontjev O.K. 1985. [Morphometry] // A.F. Treshnikov, S.S. Sal'nikov (eds.). [The Arctic and Southern Oceans]. Leningrad: Nauka. P.17-18 [in Russian].

Limits of Oceans and Seas. 1953. Monaco: The International Hydrographic Organization, 3rd Edition, Special Publication, No.23. http://www.iho-ohi.net/ iho_pubs/standard/S-23/S23_1953.pdf. Retrieved 7 February 2010.

Longhurst A.R. 1998. Ecological geography of the Sea. London: Academic Press. 398 p.

Lubinsky G. 1980. Marine bivalvia molluscs of the Canadian Central and Eastern Arctic: faunal composition and zoogeography // Canadian Bulletin of Fisheries and Aquatic Sciences. Vol.207. P.1-111.

Lütken C.F. 1857. Oversigt over Grönlands Echinodermata. Kjöbenhavn: I Commission hos C.A. Reitzels Bo og Arvinger. 109 p.

Lyubin P.A. 2003. [Fauna and ecology of the shelled gastropods of the Kara Sea] // G.G. Matishov (ed.). [Fauna of the invertebrates of the Barents, the Kara and the White Seas (information technologies, ecology, biogeography)]. Apatity: Publ. Kola Science Centre RAS. P.130-194 [in Russian].
Lyubina O.S., Sayapin V.V. 2008. [Amphipods (Amphipoda, Gammaridea) from various geographical areas. Species composition, distribution, ecology]. Apatity: Kola Science Centre RAS. 182 p. [in Russian].

Mackensen A., Sejrup H.P., Jansen E. 1985. The distribution of living benthic foraminifera on the continental slope and rise off southwest Norway // Marine Micropaleontology. Vol.9. P.275-306.

Makarov V.V. 1941. The decapod Crustacea of the Bering and Chukchi Seas // Issledovania dalnevostochnykh morei [Explorations of the Far Eastern Seas].Vol.1. P.111-163 [in Russian, English abstract].

Mauritzen C., 1996 Production of dense overflow waters feeding the North Atlantic across the Greenlan-Scotland Ridge. Part 1: Evidence for a revised circulation scheme // Deep-Sea Research I. Vol.6. P.769-806.

Mecklenburg C.W., Møller P.R., Steinke D. 2010. Biodiversity of Arctic marine fishes: taxonomy and zoogeography // Marine Biodiversity. Vol.41. P.109-140.

Meincke J. 1983. The modern current regime across the Greenland-Scotland Ridge // M.H.P. Bott, S. Saxov, M. Talwani, J. Thiede (eds). Structure and development of the Greenland-Scotland Ridge new methods and concepts. New York: Springer. P.637-652.

Menzies R.J., George R.Y., Rowe G.T. 1973. Abyssal environment and ecology of the World Ocean. N.Y.: John Wiley. 488 p.

Mirkin B.M., Naumova L.G., Solomesch A.I. 2002. [Modern science of vegetation]. Moscow: Logos. 263 p. [in Russian].

Mironov A.N. 1987. [Echinoids of the World Ocean and formation of recent faunistic complexes]. Doctoral dissertation in Biological Science. Moscow: P.P. Shirshov Institute of Oceanology of Acad. Sci. USSR. 243 p. [in Russian]

Mironov A.N. 1990. [Faunistic approach to the study of recent ecosystems] // Okeanologia [Oceanology]. Vol.30. No.6. P.1006-1012 [in Russian, English summary; English translation Oceanology. Vol.30. No.6. P.745-749].

Mironov A.N. 1999. [The problem of "pure" biogeography and delimiting of the biotic and biocenotic approaches] // Zhurnal obshchey biologii [Journal of General Biology]. Vol.60. No.2. P.213-228 [in Russian, English abstract].

Mironov A.N. 2002. [Adaptations and barriers for special dispersal] // A.P. Kuznetsov, O.N. Zezina (eds.). [Adaptation aspects of evolution of marine fauna]. Moscow: VNIRO Publ. House. P. 95-111 [in Russian, English abstract].

Mironov A.N. 2004. [Nature of the biotic boundaries] // A.I. Kafanov (ed.). [Main problems in marine biogeography: In memory of the academician O.G. Kussakin]. Vladivostok: Dalnauka. P.67-97 [in Russian].

Mironov A.N. 2012. [Delimitation of the biotic, biocenotic and landscape approaches to biogeographic regionalization: case studies of the Arctic Ocean] // M.A. Akhmetiev et al. (eds.). [Biogeography: methodology, regional and historical aspects: Proceedings of the conference dedicated to the 80-th anniversary of Vadim Nikolaevich Tikhomirov (1932 - 1997). Moscow, 30 January - 3 February 2012]. Moscow: KMK Scientific Press. P.132-135 [in Russian]. 
Mironov A.N., Dilman A.B. 2010. [Effect of the East Siberian barrier on the echinoderm dispersal in the Arctic Ocean] // Okeanologia [Oceanology]. Vol.50. No.3. P.342-355 [in Russian; English translation: Oceanology. Vol.50. No.3. P.342-355].

Mironov A.N., Gebruk A.V., Moskalev L.I. 1998. Biogeographical patterns of the hydrothermal vent fauna: a comparison with "non-vent biogeography" // Cahiers de Biologie Marine. Vol.39. P.367-368.

Mironov A.N., Gebruk A.V., Moskalev L.I. 2002. [Biogeography of hydrothermal vent communities and obligate hydrothermal taxa] // A.V. Gebruk (ed.). [Biology of Hydrothermal Systems]. Moscow: KMK Scientific Press Ltd. P.410-455 [in Russian].

Mondor C., Mercier F., Croom M., Wolotira R. 1995. Marine Region 4: Northwest Atlantic // G. Kelleher, C. Bleakley, S. Wells (eds.). A Global Representative System of Marine Protected Areas, Vol. 1. Washington: The Great Barrier Reef Marine Park Authority, The World Bank and IUCN. P.105-126.

Mork K.A., Blindheim J. 2000. Variations in the Atlantic inflow to the Nordic Seas, 1955-1996 // Deep-Sea Research I. Vol.47. P.1035-1057.

Narayanaswamy B.E., Bett B.J., Gage J.D. 2005. Ecology of bathyal polychaete fauna at an Arctic-Atlantic boundary (Faroe-Shetland Channel, North-east Atlantic) // Marine Biology Research. Vol.1. P.20-32.

Naumov A.D. 2006. [Clams of the White Sea. Ecological and faunistic analysis] // Issledovaniya fauny morei [Exploration of the Fauna of the Seas]. Vol.59 (67). P.1-367 [in Russian].

Naumov A.D., Fedyakov V.V. 1987. [Introduction] // Opredeliteli po faune SSSR [Keys to the Fauna of USSR]. Vol.151. P.205-257 [in Russian].

Negoescu I., Svavarsson J. 1997. Anthurideans (Crustacea, Isopoda) from the North Atlantic and the Arctic Ocean // Sarsia. Vol.82. P.159-202.

Nesis K.N. 1982. [Zoogeography of the World Ocean: comparison of zonation of the pelagic realm and regional subdivision of the shelf (concerning cephalopods)] // O.G. Kussakin (ed.). [Marine biogeography: Subject, methods, and principles of regionalization]. Moscow: Nauka Press. P.114-134 [in Russian].

Nesis K.N. 1987. [Cephalopods of the Arctic Ocean and its seas] A.I. Kafaniv (ed.). [Fauna and distribution of mollusks: North Pacific and Polar Basin]. Vladivostok: Far Eastern Science Center of USSR Academy of Science. P. 115-136 [in Russian].

Odum E.P. 1971. Fundamentals of Ecology. Third edition. W.B. Philadelphia, London, Toronto: Saunders Company. 574 p.

Odum E.P. 1975. Ecology. The link between the natural and social sciences. Second edition. New Delhi: Oxford \& IBH. Publishing Co. Pvt. Ltd. 244 p.

Okolodkov Yu.B. 1999. Species range types of recent marine dinoflagellates recorded from the Arctic // Grana. Vol.38. P.162-169.

Okolodkov Yu.B., Dodge J.D. 1996. Biodiversity and biogeography of planktonic dinoflagellates in the Arctic Ocean // Journal of Experimental Marine Biology and Ecology. Vol.202. P.19-27.

Ortmann A. 1896. Grundzüge der marinen Thiergeographie. Jena: G. Fischer. $96 \mathrm{~S}$.
Parmesan C., Gaines S., Gonzalez L., Kaufman D. M., Kingsolver J., Peterson A. T., Sagarin R. 2005. Empirical perspectives on species borders: from traditional biogeography to global change // Oikos. Vol. 108. P.58-75.

Pavshtiks E.A. 1985. [Zoogeographical regionalization of surface waters of the Arctic Ocean and the North Atlantic by zooplankton] // A.F. Treshnikov (ed.). [Atlas of the Arctic. Moscow: Main Department of geodesy and cartography of the Council of Ministers USSR. Map XI.14. P.129 [in Russian].

Pedersen R.B., Rapp H.T., Thorseth I.H., Lilley M.D., Barriga F.J.A.S., Baumberger T., Flesland K., Fonseca R., Früh-Green G.L., Jorgensen S.L. 2010. Discovery of a black smoker vent field and vent fauna at the Arctic Mid-Ocean Ridge // Nature Communications. Vol.1. No.126. P.1-6.

Petrov K.M. 2008. [Biogeography of the ocean]. Moscow: Alma Mater, Academical project. 328 p. [in Russian].

Petrov K.M. 2009. [Large marine ecosystems: construction principles for a hierarchial system of Arctic seas regionalization as exemplified with Baretns Sea] // Biosphera [Biosphere]. Vol.1. No.2. P.133-152 [in Russian, English abstract].

Petryashov V.V. 1989. Arctic Ocean mysids (Crustacea: Mysidacea): evolution, composition, and distribution // Y. Herman (ed). The Arctic Seas. New York: Van Nostrand. P.373-396.

Petryashov V.V. 1900. [Mysids (Crustacea: Mysidacea) of the Laptev Sea and New Siberian shoals] // Issledovaniya fauny morei [Explorations of the Fauna of the Seas]. Vol.37 (45). P.187-209 [in Russian, English abstract].

Petryashov V.V. 2002a. [Leptostraca, Mysidacea, Isopoda and Decapoda (Anomura) (Crustacea, Malacostraca) of the Chukchi Sea and adjacent waters: habitat conditions and species composition] // Biologiya Morya [Russian Journal of Marine Biology]. Vol.28. No.2. P.85-92 [in Russian, English abstract].

Petryashov V.V. 2002b. [Leptostraca, Mysidacea, Isopoda and Decapoda (Anomura) (Crustacea, Malacostraca) of the Chukchi Sea and adjacent waters: biogeography and history of fauna formation] // Biologiya Morya [Russian Journal of Marine Biology]. Vol.28. No.3. P.161-169 [in Russian, English abstract].

Petryashov V.V. 2004. [Mysids (Crustacea, Mysidacea) of the Eurasiatic subbasin of the Arctic basin and the adjacent seas: the Barents, Kara and Laptev Seas] // Issledovania fauny morei [Explorations of the Fauna of the Seas].Vol.54 (62). P.124-145 [in Russian].

Petryashov V.V. 2009. [Biogeographical division of the Arctic and North Atlantic based on the fauna of mysids (Crustacea: Mysidacea)] // Biologiya Morya [Russian Journal of Marine Biology]. Vol.35. No.2. P.87-106 [in Russian, English abstract].

Petryashov V.V., Vasilenko S.V., Voronkov A.Yu., Sirenko B.I., Smirnov A.V., Smirnov I.S., Chaban E.M. 2010. [Biogeographical analysis of macrobenthos fauna of the Est Siberian Sea and reconstruction of the fauna forming ways] // Issledovania fauny morei [Explorations of the Fauna of the Seas]. Vol.66 (74). P.160-177 [in Russian, English abstract].

Petryashov V.V., Vassilenko S.V., Voronkov A.Yu., Sirenko B.I., Smirnov A.V., Smirnov I.S. 2013. Biogeo- 
graphical analysis of the Chikchi Sea and adjacent waters based on fauna of some macrobenthos taxa // Invertebrate Zoology. Vol.10. No.1. P.49-68.

Pidwirny M. 2006. Introduction to the Oceans. Fundamentals of Physical Geography, 2nd Edition. Date Viewed: 2013 March. http://www.physicalgeography.net/fundamentals/8o.html

Pielou E.C. 1979. Biogeography. New York: Wiley-Interscience. $351 \mathrm{p}$.

Price T.D., Kirkpatrick M. 2009. Evolutionarily stable range limits set by interspecific competition // Proceedings of the Royal Society. Ser.B. Vol.276. P.14291434.

Rapoport E.H. 1982. Areography. Geographical strategies of species. Oxford: Pergamon Press. 269 p.

Rapp H.S., Schander C., Konsgrud J.A., Alvestad T., Byrkjedal I., Tverberg J., Hestetun J.T., Stee I.H. et al. 2011. Investigation of a unique fauna from hydrothermal vents along the Arctic Mid-ocean Ridge (AMOR) // World Conference on Marine Biodiversity. Our Oceans, Our Future. 26-36 September 2011, Aberdeen. Oral abstract booklet. Aberdeen: Scotland (UK). P.121.

Razumovsky S.M. 1999. [Selected works]. Moscow: KMK Scientific Press. 560 p. [in Russian].

Reaka M.L., Rodgers P.J., Kudla A.U. 2008. Patterns of biodiversity and endemism on Indo-West Pacific coral reefs // The Proceedings of the National Academy of Sciences USA. Vol.105. P.11471-11481.

Remane A. 1934. Die Brackwasserfauna // Zoologische Anzeiger (Suppl.). Bd.7. S.34-74.

Remane A. 1940. Einführing in die zoologische Ökologie der Nord- und Ostsee // Tierwelt der Nord- und Ostsee. Bd.34. No.Ia. S.1-238.

Roy K., Hunt G., Jablonski D., Krug A.Z., Valentine J.W. 2009. A maxroevolutionary perspective on species range limits // Proceedings of the Royal Society. Ser.B. Vol.276. P.1485-1493.

Schander C., Rapp H.T., Kongsrud J.A., Bakken T., Berge J., Cochrane S., Oug E., Byrkjedal I., Todt C., Cedhagen T., Fosshagen A., Gebruk A., Larsen K., Levin L., Obst M., Pleijel F., Stöhr S., Warén A., Mikkelsen N., Therese H.-J., Silje K., Rozemarijn P., Kristin H., Thorseth, I.H., Pedersen R.B. 2010. The fauna of hydrothermal vents on the Mohn Ridge (North Atlantic) // Marine Biology Research. Vol.6. No.2. P.155-171.

Schmarda L.K. 1853. Die geographische Verbreitung der Tiere. Die Tierwelt der Oceanis. Bd.3. Wien: Gerold und Sohn. S.583-756.

Schmidt P.Yu. 1904. [Fishes of the eastern seas of the Russian Empire]. St.-Petersburg: Russian Emperor Geographic Society Publishing. 466 p. [in Russian].

Semenov V.N. 1982. [Biogeographical zonation of the South American shelf based on classification of species areals of benthic invertebrates] // O.G. Kussakin (ed.). [Marine biogeography. Subject, methods, and principles of zonality]. Moscow: Nauka Press. P.184269 [in Russian].

Semenov V.N. 1986. On the fauna, faunistic complex and logical structure of the concept " element of biota " in biogeography // Trudy Vsesouyznogo gidrobiologicheskogo obtchestva [Proceedings of the AllUnion Hydrobiological Society]. Vol.27. P.76-90 [in Russian].
Semina G.I. 1997. An outline of the geographical distribution of oceanic phytoplankton // Advances in Marine Biology. Vol.32. P.527-563.

Shorygin A.A. 1928. [Die Echinodermen des Barentsmeeres] // Berichte des Wissenschaftlichen Meeresinstituts. Bd.3. H.4. S.1-128 [in Rissian, German summary].

Sirenko B.I. 1998. [Arctic marine fauna: results from expeditions of the Zoological Institute of the Russian Academy of Sciences] // Biologiya Morya [Russian Journal of Marine Biology]. Vol.24. No.6. P.341-350 [in Russian, English abstract].

Sirenko B.I., Vassilenko S.V., Petryashov V.V. 2009. Distribution patterns for shelf species of Eurasian Arctic Seas // S.V. Vassilenko, V.V. Petryashov (eds.). Illustrated keys to free-living Invertebrates of Eurasian Arctic Seas and adjacent deep waters. Vol.1. University of Alaska Fairbanks: Alaska Sea Grant. P.179-186.

Smirnov A.V., Smirnov I.S. 1990. [Echinoderms from the Laptev Sea // Issledovaniya fauny morei [Explaration of the Fauna of the Seas]. Vol.37 (45). P.411-462 [in Russian, English abstract].

Smirnov A.V., Smirnov I.S. 1994. [Echinoderms of the East Siberian Sea // Issledovaniya fauny morei [Explaration of the Fauna of the Seas]. Vol. 49 (57). P.131-182 [In Russian, English abstract].

Smirnov A.V., Smirnov I.S. 2006. [New echinoderms findings in the Laptev Sea (1993-1998 expeditions)] // Issledovaniya fauny morei [Exploration of the Fauna of the Seas]. Vol. 56 (64). P.93-147 [in Russian, English abstract].

Smirnov A.V., Smirnov I.A., 2010. Echinodermata of the Chukchi Sea and Bering Straight // Issledovaniya fauny morei [Exploration of the Fauna of the Seas]. Vol.64 (72). P.154-199 [in Russian, English abstract].

Spalding M.D., Fox H.E., Allen G.R., Davidson N., Ferdaña Z.A., Finlayson M., Halpern B.S., Jorge M.A., Lombana A., Lourie S.A., Martin K.D., McManus E., Molnar J., Recchia C.A., Robertson J. 2007. Marine ecoregions of the world: a bioregionalization of coastal and shelf areas // Bioscience. Vol.57. No.7. P.573-583.

Starobogatov Ya.I. 1982. [Problem of minimum subdivision in biogeography and its appliance to faunistic (faunogenetic) marine zoogeography] // O.G. Kussakin (ed.). [Marine biogeography. Subject, methods, and principles of zonality]. Moscow: Nauka Press. P.12-18 [in Russian].

Steffens M., Piepenburg D., Schmid M.K. 2006. Distribution and structure of macrobenthic fauna in the eastern Laptev Sea in relation to environmental factors // Polar Biology. Vol.29. P.837-848.

Stein R. 2000. Circum Arctic river discharge and its geological records // International Journal of Earth Science. Vol.89. P.447-449.

Sukachev V.N. 1964. [Basic concepts of the forest biogeocenology] // V.N. Sukachev, N.V. Dylis (eds.). [Fundamentals of forest biogeocenology]. Moscow: Nauka Press. P.467-482 [in Russian].

Svavarsson J., Brattegard T., Strömberg J.-O. 1990. Distribution and diversity patterns of asselote isopods (Crustacea) in the deep Norwegian and Greenland Seas // Progress in Oceanography. Vol.24. P.297310. 
Svavarsson J., Strömberg J.-O., Brattegard T. 1993. The deep-sea asselote (Isopoda, Crustacea) fauna of the northern seas: species composition, distributional patterns and origin// Journal of Biogeography. Vol.20. P.537-555.

Szafer W. 1952. Zarys ogolnej geografii roslin [An outline of general plant geography]. Warszawa: Panstwowe Wydawn. Naukowe. 428 p.

Tansley A.G. 1935.The use and abuse of vegetational concepts and terms // Ecology. Vol.16. P.284-307.

Tarasov V.G., Gebruk A.V., Mironov A.N., Moskalev L.I. 2005. Deep-sea and shallow-water hydrothermal vent communities: Two different phenomena? // Chemical Geology. Vol.224. No.1-3. P.5-39.

Tolmachev A.I. 1931. [On methods for comparative floristic studies: 1. The concept of flora in comparative floristics] // Zhurnal Russkogo Botanicheskogo Obchestva. Vol.16. No.1. P.111-124 [in Russian].

Tolmachev A.I. 1974. [Introduction to plant geography]. Leningrad: Leningrad State University Press. 244 p. [in Russian]

Treshnikov A.F. (ed.). 1985. [Atlas of the Arctic]. Moscow: Main Department of geodesy and cartography of the Council of Ministers USSR. 204 p. [in Russian]

Tsvetkova N.L. 1985. [Species of the endemic genus Portlandia (Mollusca-Bivalvia) and the endemic arctic species of the North-Pacific genus Arcturus (Isopoda). Zoogeographical regionalisation of benthos] / / A.F. Treshnikov (ed.). Atlas of the Arctic, Moscow: Main Department of geodesy and cartography of the Council of Ministers USSR. Map XI. 21. P.132 [in Russian]

Tunnicliffe V., McArthur A.G., McHugh D. 1998. A biogeographical perspective of the deep-sea hydrothermal vent fauna // Advances in Marine Biology. Vol.34. P.353-442.

Tyler P.A., Young C.M.Y. 2003. Dispersal at hydrothermal vents: a summary of recent progress // Hydrobiologia. Vol.503. No.1-3. P.9-19.

Udvardy M.D.F. 1969. Dynamic Zoogeography. New York: Van Nostrand Reinhold Co. 445 p.

Valentine J.W. 1966. Numerical analysis of marine molluscan ranges on the extra-tropical northeastern Pacific shelf // Limnology and Oceanography. Vol.11. P.198-211.

Van Dover C.L., German C.R., Speer K.G., Parson L.M., Vrijenhoek R.C. 2002. Evolution and biogeography of deep-sea vent and seep invertebrates // Science. Vol. 295. P.1253-1257.

Vassilenko S.V. 1974. [Caprellids (skeleton shrimps) of the seas of the USSR and adjacent waters] // Opredeleliteli po Faune SSSR [Keys to the Fauna of the USSR]. Vol.107. 288 p. [in Russian].

Vassilenko S.V. 1990. [Cumacea of the Laptev Sea, New Siberian shoals and adjoining deep water part of the Arctic Ocean] // Issledovaniya fauny morei [Explorations of the Fauna of the Seas]. Vol.37 (45). P.210 234 [in Russian]..

Vassilenko S.V. 2001. Order Cumacea // Issledovaniya fauny morei [Exploration of the Fauna of the Seas]. Vol.51(59). P.95-96 [in Russian].

Vassilenko S.V. 2002. [Cumaceans (Crustacea, Malacostraca) as indicators of Atlantic waters over the continental slope of the Arctic Ocean] // Biologiya Morya
[Russian Journal of Marine Biology]. Vol.28. No.1. P.13-18 [in Russian].

Vassilenko S.V. 2004. [Regularities of the distribution and biogeographic structure of the cumacean fauna of the Laptev Sea, north-west part of the East-Siberian Sea and adjacent deep-waters of the Arctic in connection with peculiariries of hydrologic regime] // Issledovaniya fauny morei [Explorations of the Fauna of the Seas]. Vol.54 (62). P.15-57 [in Russian, English abstract].

Vassilenko S.V. 2008a. [Composition, distribution and biogeographical structure of the cumacean fauna (Crustacea, Peracarida) of the Chukchi Sea] // Issledovaniya fauny morei [Explorations of the Fauna of the Seas]. Vol.61 (69). P.111-134 [in Russian, English abstract]

Vassilenko S.V. 2008b. [Cumacea (Crustacea, Peracarida) of the upper part of the continental slope adjacent to the Chukchi Sea (from material of the drift-ice unit "SP-22", 1978-79)] // Issledovaniya fauny morei [Explorations of the Fauna of the Seas]. Vol.61 (69). P.135-141 [in Russian, English abstract].

Vassilenko S.V. 2010. [Cumaceans (Crustacea, Peracarida, Cumacea) of the East Siberian Sea] // Issledovania fauni morei [Explorations of the Fauna of the Seas]. Vol.66 (74). P.49-65 [in Russian, English abstract].

Vinogradova N.G. 1997. Zoogeography of the Abyssal and Hadal Zones // Advances in Marine Biology. Vol.32. P.325-387.

Walter G., Alekhin V.V. 1936. [Foundations of botanic geography]. Moscow-Leningrad: Biomedgiz. 716 p. [in Russian]

Watling L., Guinotte J., Clark M.R., Smith C.R. 2013. A proposed biogeography of the deep ocean floor. Progress in Oceanography. http://dx.doi.org/10.1016/ j.pocean.2012.11.003.

Weisshappel J. 2000. Distribution and diversitry of the hyperbenthic amphipod family Eusiridae in the different seas around the Greenland-Iceland-Faeroe-Ridge // Sarsia. Vol.85. No.3. P.227-236.

Weisshappel J. 2001. Distribution and diversitry of the hyperbenthic amphipod family Calliopiidae in the different seas around the Greenland-Iceland-FaeroeRidge // Sarsia. Vol.86. P.143-151.

Wlodarska-Kowalczuk M., Kendall M.A., Weslawski J.M., Klages M., Soltwedel T. 2004. Depth gradients of benthic standing stock and diversity on the continental margin at a high latitude ice-free site (off West Spitsbergen, $79^{\circ} \mathrm{N}$ ) // Deep-Sea Research I. Vol.51. P.1903-1914.

Wood A.M., Whatley R.C. 1994. Northeastern Atlantic and Arctic faunal provinces based on the distribution of Recent ostracod genera // Holocene. Vol.4. No.2. P.174-192.

Woodward S.P. 1866. Manual of the Mollusca: a treatise on Recent and fossil shells. 2nd edition. London: Virtue Brothers \& Co. 542 p.

Zenkevitch L.A. 1947. [Fauna and biological productivity of the sea]. Moscow: Izdatelstvo Sovetskaya Nauka. 588 p. [in Russian].

Zenkevitch L.A. 1963a. [Biology of the seas of the U.S.S.R]. Moscow: Academy of Science of USSR Press. 740 p. [in Russian]. 
Zenkevitch L.A. 1963b. Biology of the seas of the U.S.S.R. London: George Allen \& Unwin Ltd. 955 p.

Zenzerov V.S., Frolova E.A., Kuzmin S.A., Denisenko N.V., Anisimova N.A. 2006. [Zoobenthos of the seas in the North-West sector of the Arctic: results of long-term investigations] // G.G. Matishov (ed.). [Oceanological and biological investigations of the Russia Arctic and Southern seas (to $70^{\text {th }}$ anniversary of the Murmansk Marine Biological Institute)]. Apatity: Publ. KSK RAS. P.277-298 [in Russian, En- glish abstract].

Zimmer C. 1900. Die arktischen Cumacean // Fauna Arctica. Bd.1. No.3. S.409-444.

Zimmer C. 1904. Die Arktischen Schizopoden // Fauna Arctica. Bd.3. S.415-492.

Zinova A.D. 1985. [Phytogeographical regionalization of macrophytes] // A.F. Treshnikov (ed.). [Atlas of the Arctic]. Moscow: Main Department of geodesy and cartography of the Council of Ministers USSR. Map XI, 23. P.132 [in Russian]. 